\title{
RECEIVED
}

JAN 251996

Q.S.T

\section{Contamination Source Review for Building E5032, Edgewood Area, Aberdeen Proving Ground, Maryland}




\section{Argonne National Laboratory}

Argonne National Laboratory, with facilities in the states of Illinois and Idaho, is owned by the United States Government, and operated by the University of Chicago under the provisions of a contract with the Department of Energy.

This technical memo is a product of Argonne's Energy Systems (ES) Division. For information on the division's scientific and engineering activities, contact:

Director, Energy Systems Division

Argonne National Laboratory

Argonne, Illinois 60439-4815

Telephone (708) 252-3724

Presented in this technical memo are preliminary results of ongoing work or work that is more limited in scope and depth than that described in formal reports issued by the ES Division.

Publishing support services were provided by Argonne's Information and Publishing Division (for more information, see IPD's home page: http://www.ipd.anl.gov/).

\section{Disclaimer}

This report was prepared as an account of work sponsored by an agency of the United States Government. Neither the United States Government nor any agency thereof, nor any of their employees, makes any warranty, express or implied, or assumes any legal liability or responsibility for the accuracy, completeness, or usefulness of any information, apparatus, product, or process disclosed, or represents that its use would not infringe privately owned rights. Reference herein to any specific commercial product, process, or service by trade name, trademark, manufacturer, or otherwise, does not necessarily constitute or imply its endorsement, recommendation, or favoring by the United States Government or any agency thereof. The views and opinions of authors expressed herein do not necessarily state or reflect those of the United States Government or any agency thereof.

Reproduced directly from the best available copy.

Available to $D O E$ and DOE contractors from the Office of Scientific and Technical Information, P.O. Box 62, Oak Ridge, TN 37831; prices available from (423) 576-8401.

Available to the public from the National Technical Information Service, U.S. Department of Commerce, 5285 Port Royal Road, Springfield, VA 22161. 


\section{DISCLAMIER}

Portions of this document may be illegible in electronic image products. Images are produced from the best available original document. 


\section{Contamination Source Review for Building E5032, Edgewood Area, Aberdeen Proving Ground, Maryland}

M.N. Booher, D.P. O'Reilly, M.P. Smits, K.L. Brubaker, J.M. Dougherty,

C. Tome, A.K. Draugelis, J. Rueda, and R.E. Zimmerman

Center for Environmental Restoration Systems, Energy Systems Division,

Argonne National Laboratory, 9700 South Cass Avenue, Argonne, Illinois 60439

\section{Published as}

Contamination Source Review Edgewood Area, Aberdeen Proving

Ground, Maryland -

Building E5032

September 1995

Work sponsored by United States Department of Defense, United States Army, Aberdeen Proving Ground, Maryland 
68

This report is printed on recycled paper. 


\section{Contents}

Summary

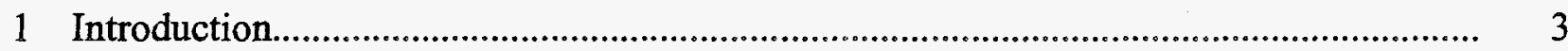

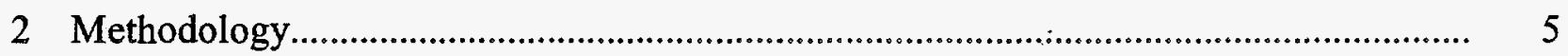

3 Historical Record Search .................................................................................................... 6

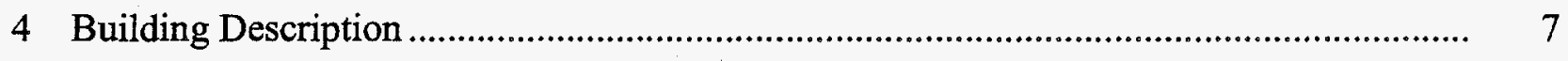

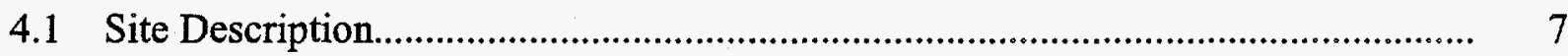

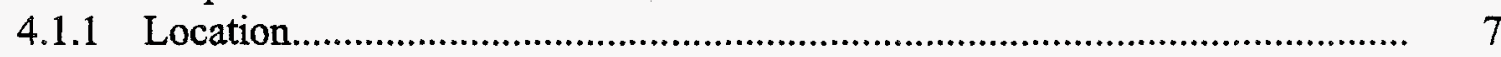

4.1.2 Proximity to Other Buildings ......................................................................... 8

4.1.3 Building Structure..................................................................................... 8

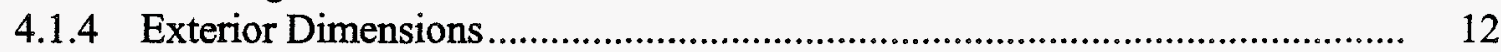

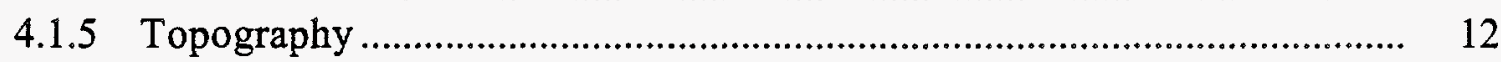

4.1.6 Vegetation in the Immediate Vicinity ............................................................. 12

4.1.7 External Aboveground Structures or Equipment............................................ 12

4.1.8 Connections with Adjacent Buildings ........................................................... 13

4.1.9 Underground Structures ..................................................................... 13

4.1.10 Surface Drainage System............................................................................. 13

4.1.11 Utility Access Points ................................................................................ 13

4.1.12 Exterior Piping...................................................................................... 14

4.1.13 Nearby Roads and Sidewalks ............................................................. 14

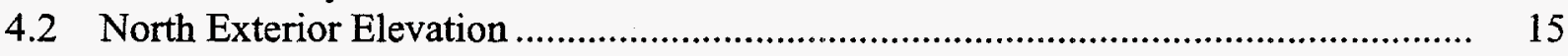

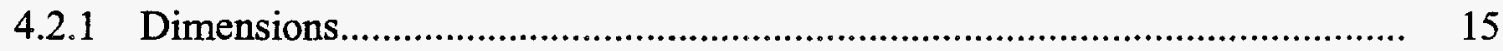

4.2.2 Construction Materials ………................................................................ 15

4.2.3 Doors and Windows........................................................................... 15

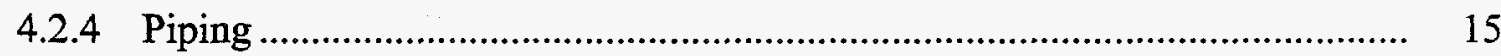

4.2.5 Utility Connections................................................................................. 15

4.2.6 External Equipment or Structures .............................................................. 15

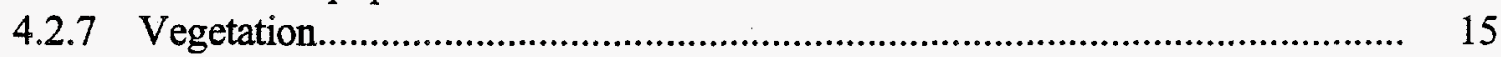

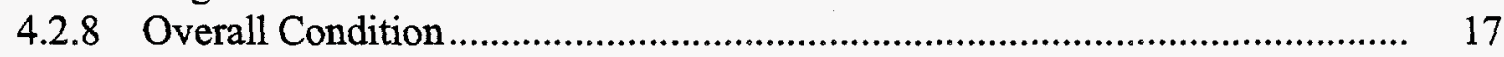

$4.3 \quad$ East Exterior Elevation........................................................................................ 17

4.3.1 Dimensions............................................................................................. 17

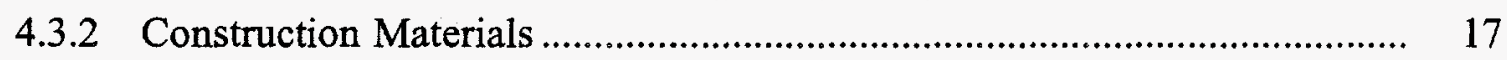

4.3.3 Doors and Windows............................................................................. 17

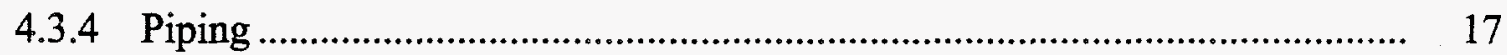

4.3.5 Utility Connections....................................................................................... 17

4.3.6 External Equipment or Structures …………................................................ 19

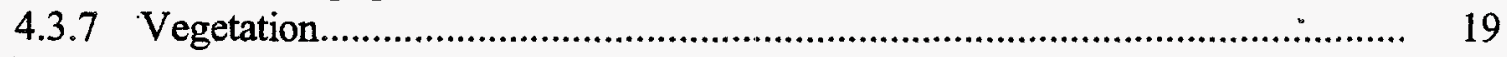

4.3.8 Overall Condition .................................................................................. 19 


\section{Contents (Cont.)}

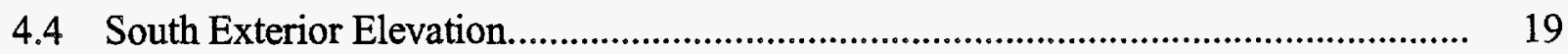

4.4.1 Dimensions................................................................................................. 19

4.4.2 Construction Materials .......................................................................... 19

4.4.3 Doors and Windows............................................................................... 19

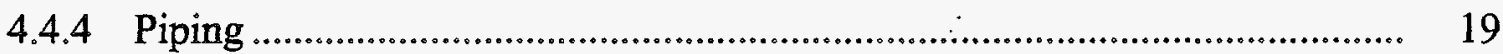

4.4.5 Utility Connections.................................................................................... 21

4.4.6 External Equipment or Structures .............................................................. 21

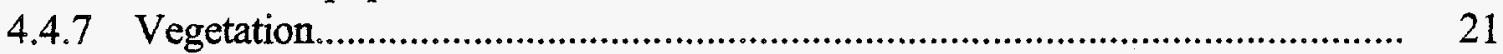

4.4.8 Overall Condition.............................................................................. 21

4.5 West Exterior Elevation.................................................................................... 21

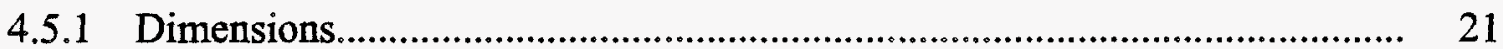

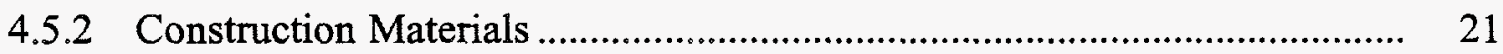

4.5.3 Doors and Windows.................................................................................. 23

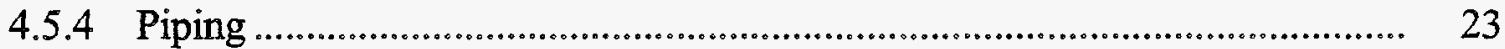

4.5.5 Utility Connections................................................................................... 23

4.5.6 External Equipment or Structures ................................................................. 23

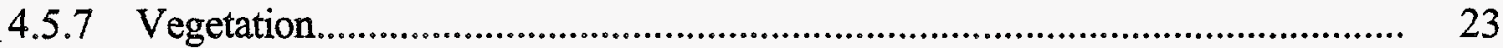

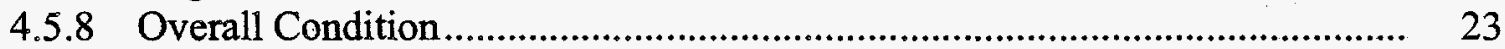

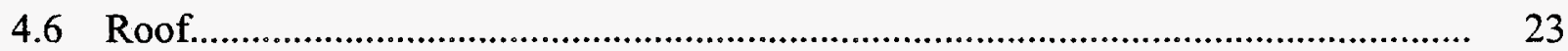

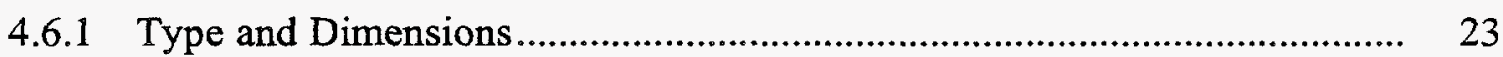

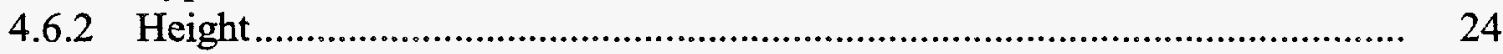

4.6.3 Surface Materials............................................................................ 24

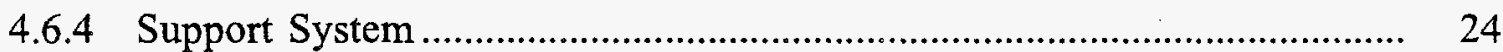

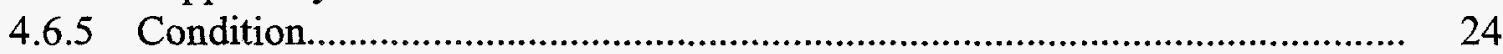

4.6.6 Equipment Located on Roof ...................................................................... 24

4.6.7 Chimneys, Roof Vents, or Vent Stacks........................................................ 24

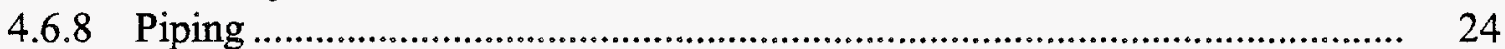

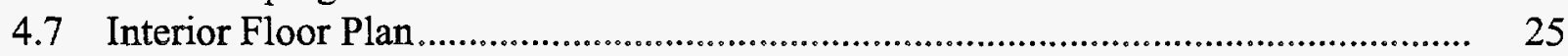

4.7.1 Room Numbers and Dimensions................................................................. 25

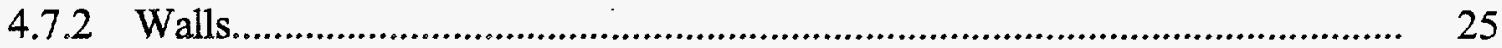

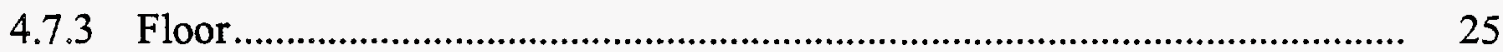

4.7.4 Floor Penetrations ............................................................................... 26

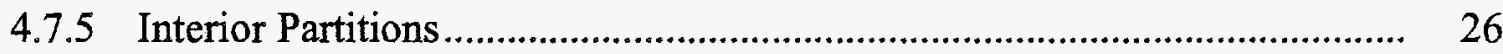

4.7.6 Equipment or Supplies............................................................................... 26

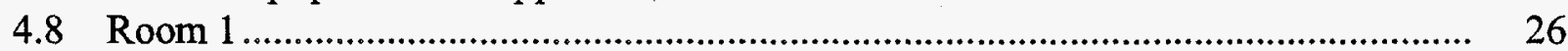

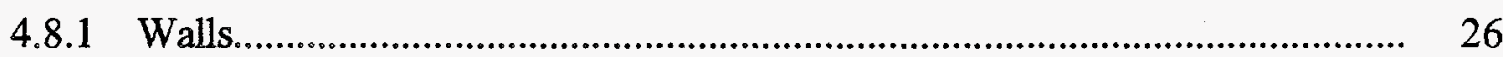

4.8.2 Finish Materials ............................................................................ 26

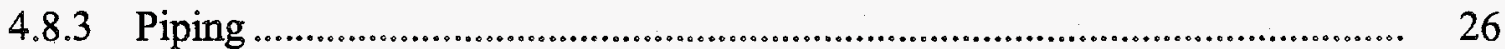

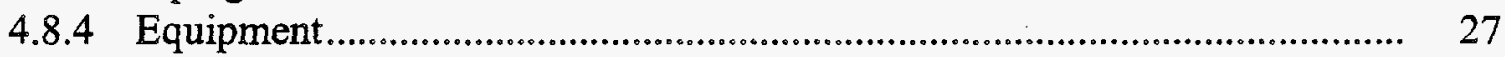

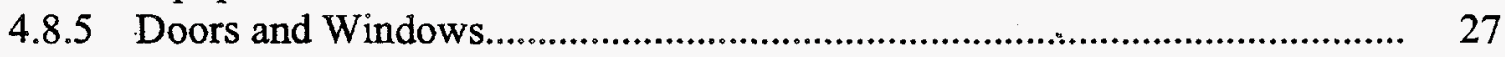

4.8.6 Ceiling and Floor .................................................................................. 27 


\section{Contents (Cont.)}

4.9 Room 2

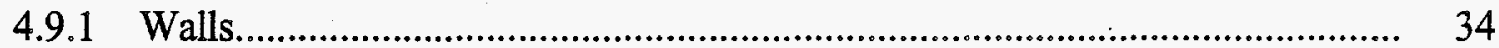

4.9.2 Finish Materials ................................................................................. 34

4.9.3 Piping ..................................................................................... 34

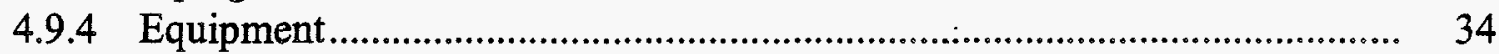

4.9.5 Doors and Windows........................................................................... 34

4.9.6 Ceiling and Floor ........................................................................................ 39

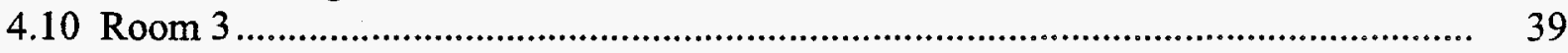

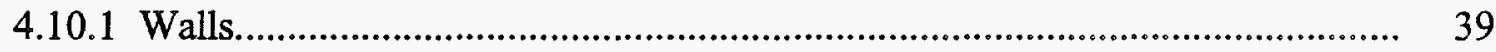

4.10.2 Finish Materials ....................................................................................... 39

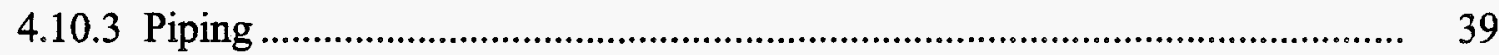

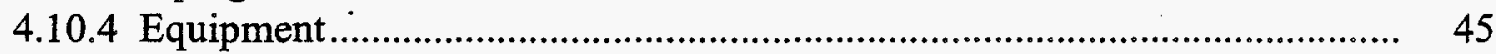

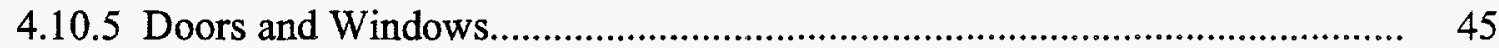

4.10.6 Ceiling and Floor ............................................................................... 45

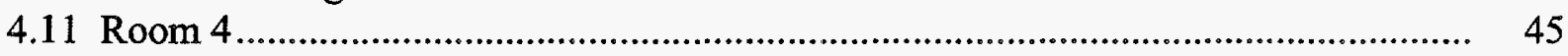

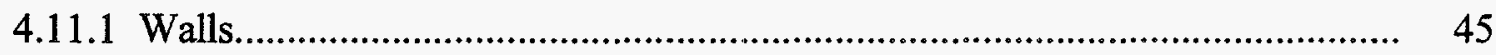

4.11.2 Finish Materials ...................................................................................... 45

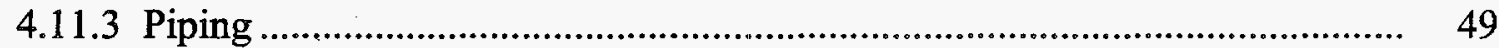

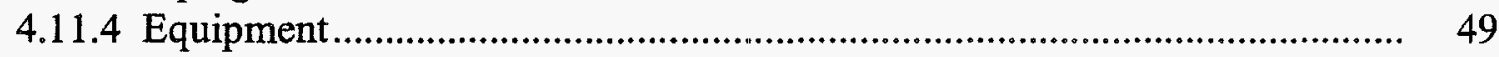

4.11.5 Doors and Windows........................................................................... 49

4.11.6 Ceiling and Floor ................................................................................. 49

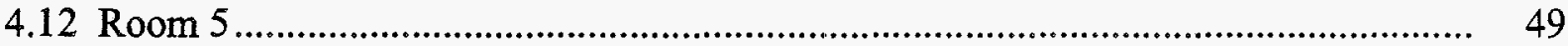

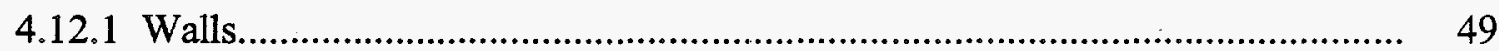

4.12.2 Finish Materials ............................................................................... 49

4.12.3 Piping ............................................................................................... 56

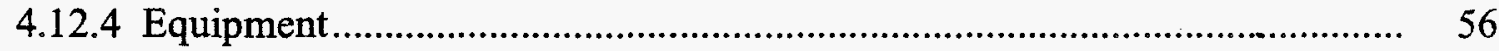

4.12.5 Doors and Windows.............................................................................. 56

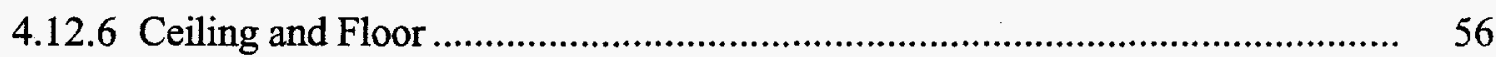

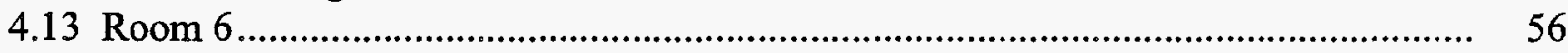

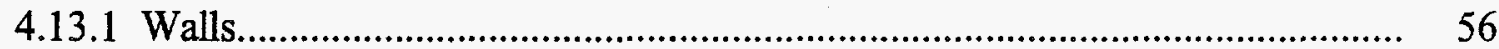

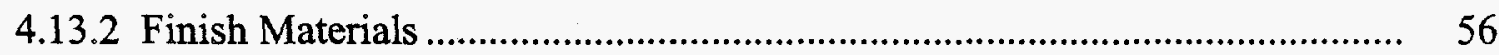

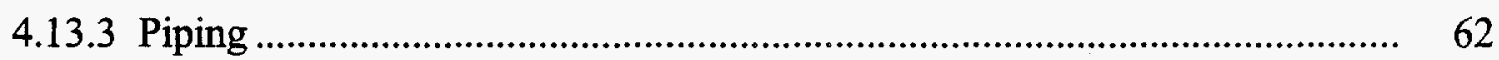

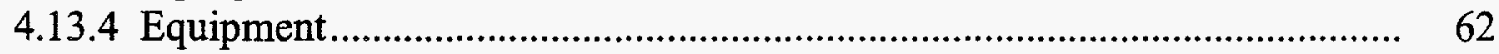

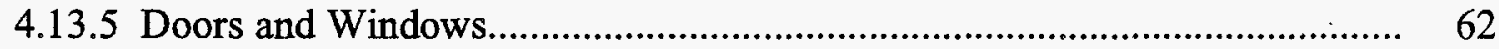

4.13.6 Ceiling and Floor .................................................................................... 62

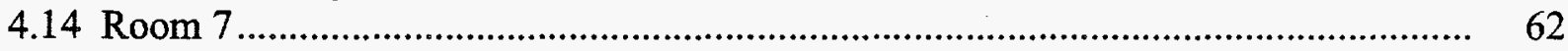

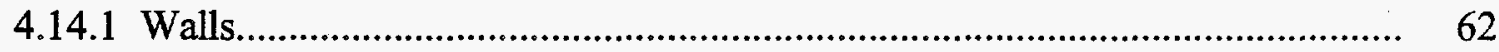

4.14.2 Finish Materials ............................................................................. 62

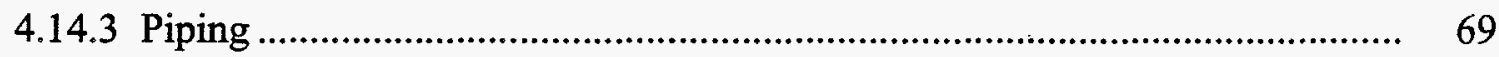

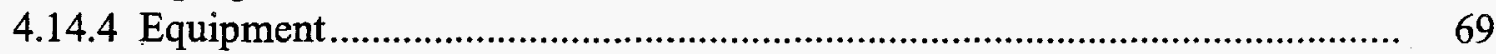

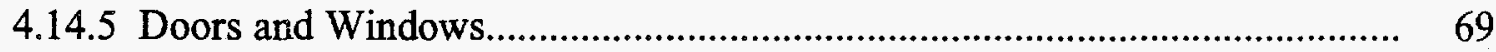

4.14.6 Ceiling and Floor ...................................................................................... 69 


\section{Contents (Cont.)}

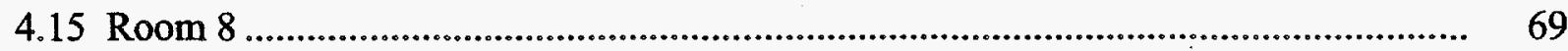

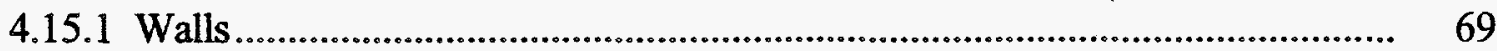

4.15.2 Finish Materials......................................................................................... 69

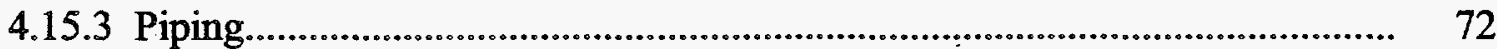

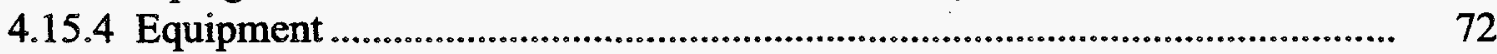

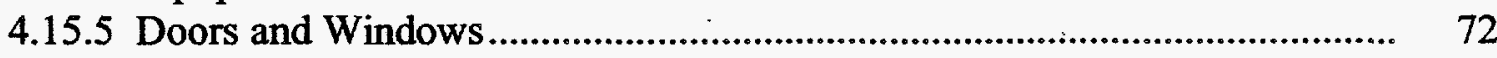

4.15.6 Ceiling and Floor...................................................................................... 72

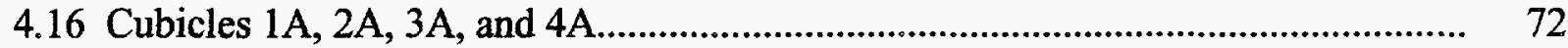

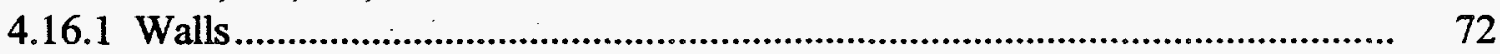

4.16.2 Finish Materials......................................................................................... $\quad .72$

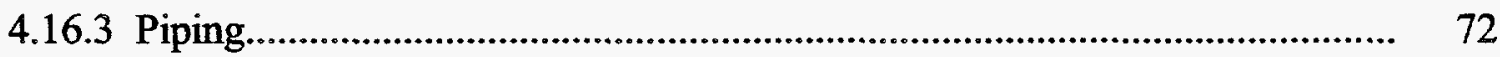

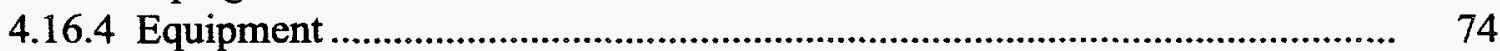

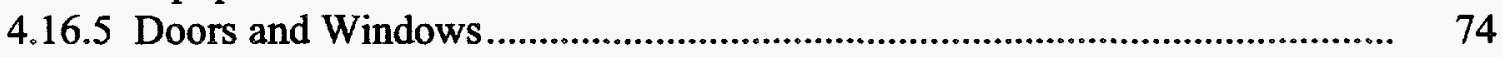

4.16.6 Ceiling and Floor.......................................................................................... 74

5 Geophysical Investigation................................................................................................ 75

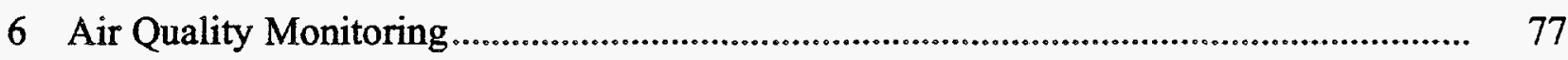

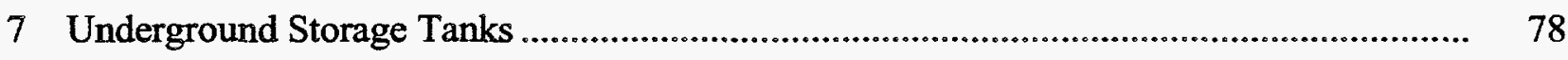

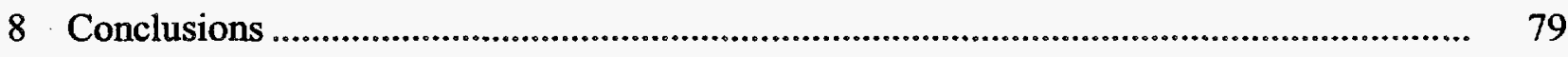

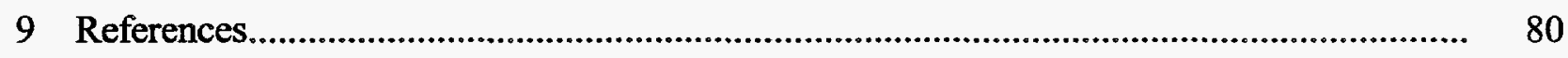

Appendix A: Field Investigation of Hazardous Material Facilities for Building E5032.......... 81

Figures

1 Map of Aberdeen Proving Ground Location............................................................................

2 Map of Building E5032 Location.................................................................................... 7

3 Building E5032 Plot Plan......................................................................................

4 Building E5032 Floor Plan............................................................................................. 10

5 Photographs of Building E5032 Exterior .............................................................................. 11

6 Building E5032 North Exterior Elevation .......................................................................... 16 


\section{Figures (Cont.)}

7 Building E5032 East Exterior Elevation ................................................................ 18

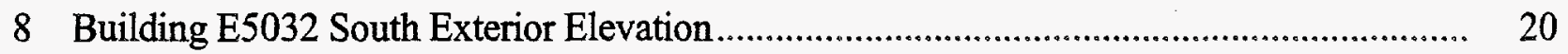

9 Building E5032 West Exterior Elevation ............................................................. 22

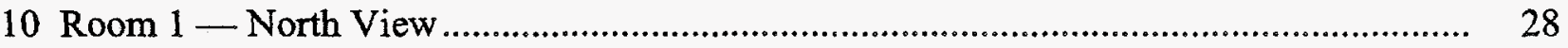

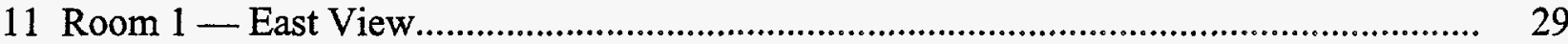

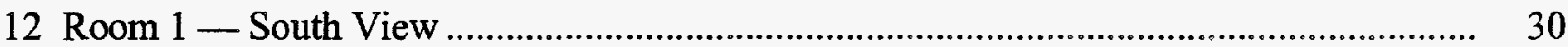

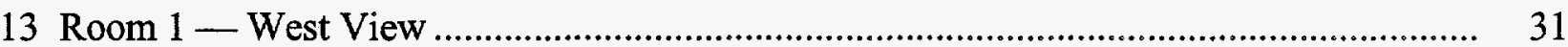

14 Photographs of Room 1 Walls ........................................................................ 32

15 Photographs of Room 1 - Walls, Ceiling, and Floor ................................................. 33

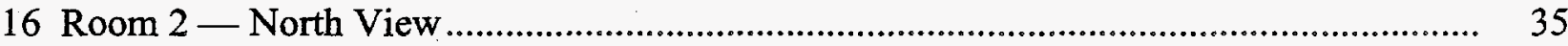

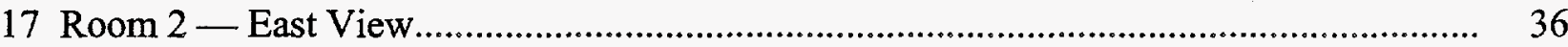

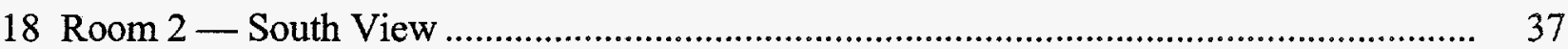

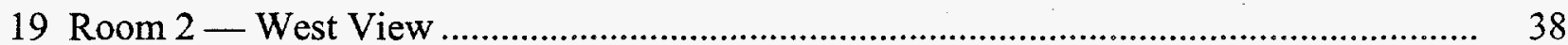

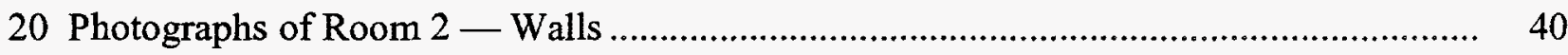

21 Photographs of Room 2 - Ceiling and Floor ........................................................ 41

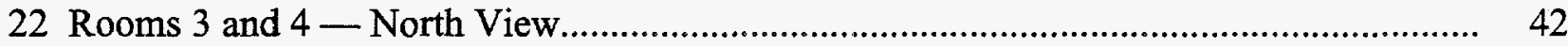

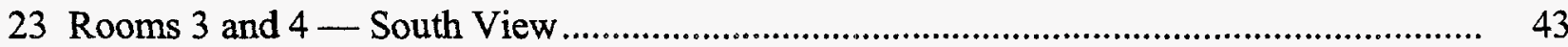

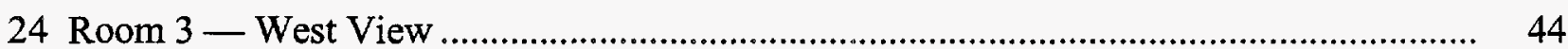

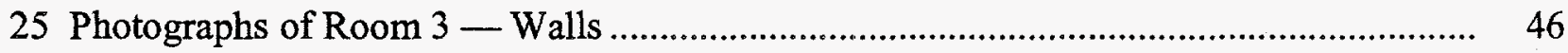

26 Photographs of Room 3 - Walls and Ceiling ....................................................... 47

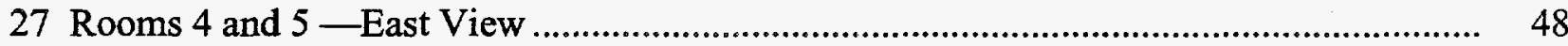

28 Photographs of Room 4 - Walls ......................................................................... 50

29 Photographs of Room 4 — Ceiling and Floor....................................................

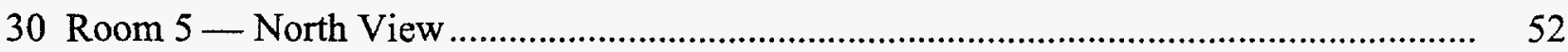




\section{Figures (Cont.)}

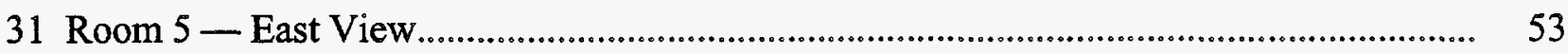

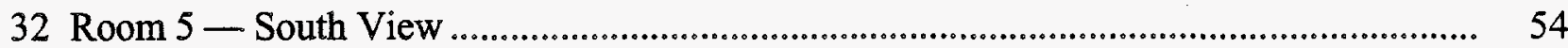

33 Room 5 - West View .......................................................................................... 55

34 Photographs of Room 5 - Walls ............................................................................. 57

35 Photographs of Room 5 - Ceiling and Floor ..................................................................... 58

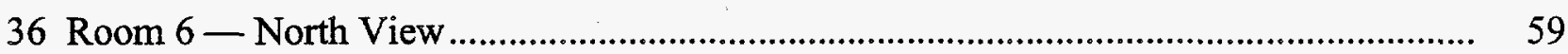

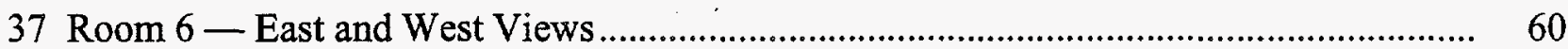

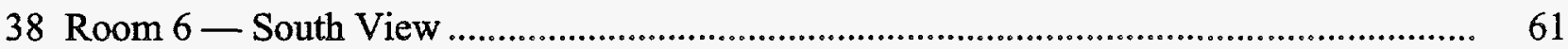

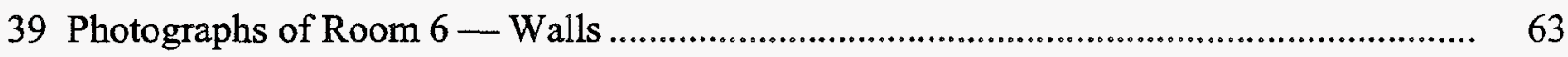

40 Photographs of Room 6 - Ceiling and Floor ....................................................................... 64

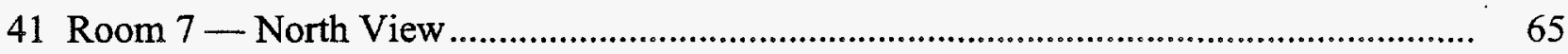

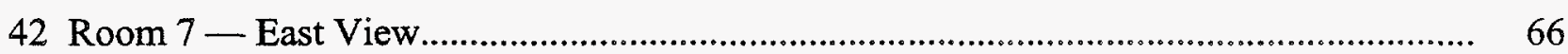

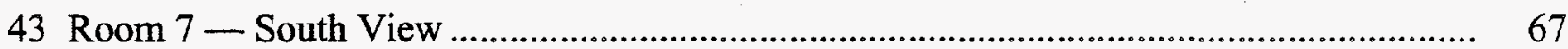

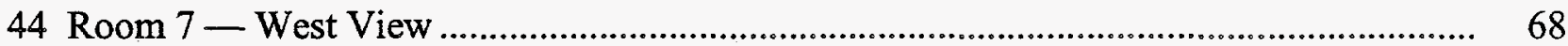

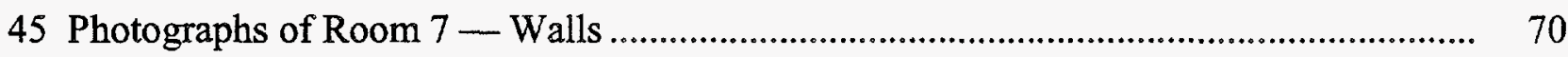

46 Photographs of Room 7 - Ceiling and Floor ..................................................................... 71

47 Photographs of Room 8 - Walls, Ceiling, and Floor ........................................................ 73 


\title{
Contamination Source Review for Building E5032, Edgewood Area, Aberdeen Proving Ground, Maryland
}

\author{
by \\ M.N. Booher, D.P. O'Reilly, M.P. Smits, K.L. Brubaker, \\ J.M. Dougherty, C. Tome, A.K. Draugelis, \\ J. Rueda, and R.E. Zimmerman
}

\section{Summary}

This report was prepared by Argonne National Laboratory (ANL) to document the results of a contamination source review of Building E5032 at the Aberdeen Proving Ground (APG) in Maryland. The report may be used to assist the U.S. Army in planning for the future use or disposition of this building. The review included a historical records search, physical inspection, photographic documentation, geophysical investigation, and review of available records regarding underground storage tanks associated with Building E5032. The field investigations were performed by ANL during 1994 and 1995.

Building E5032 (APG designation), originally known as Building 99, is located at the northwest corner of the intersection of Hoadley Road and Magnolia Road in the Edgewood Area of APG. The building was constructed during World War I as an incendiary bomb filling plant. During the 1920s and 1930s, Building E5032 was maintained as a filling facility; incendiary bombs were produced here during at least a portion of these two decades. The building was used during at least a portion of World War II as a pilot plant for the development of a dry white phosphorus filling process. Since World War II, the building has been used primarily for both wet and dry methods for white phosphorus filling pilot studies. Most of the dry filling methods were developed in Building E5032 between 1965 and 1970. Other filling operations in Building E5032 have included mustard during the period shortly after World War II and triethyl aluminum (TEA) during the late 1960s and early 1970s. During the World War II period, the building was connected to the sanitary sewer system with one large and at least one small interior sump. There are also seven sumps adjacent to the exterior of the building: two on the west elevation, four near the four bays on the south elevation, and one at the northeast comer of the building. All of these sumps are connected with the chemical sewer system and received most, if not all, of the production operation wastewater. The discharge from this system was released into the east branch of Canal Creek; the discharge pipe was located southeast of Building E5032. There are no records indicating the use of Building E5032 after 1974, and it is assumed that the building has been out of service since that time.

The physical inspection and photographic documentation of Building E5032 were completed in November 1994. Numerous exterior concrete pads, sumps, aprons, and drainage ditches were observed near the building. The main building is a steel structure covered by 
corrugated sheet metal. An addition on the south side of the main building is constructed of cinder block. The addition consists of four small cubicles. The interior of the main building contains eight rooms. The interior walls and partitions are constructed of common wood framing with a finished gypsum board, or multicelled ceramic construction building block. Several areas of the concrete floor have been built up for reinforcement to support heavy equipment. In another area of the building, a portion of the floor has been removed and a large hole remains. A metal grate in one of the rooms provides access to a vaulted area under the floor. The extent, inlets, and outlets of this vaulted area are unknown; the area was filled with water to a depth approximately $2 \mathrm{ft}$ below the top of the concrete floor. This vaulted area may discharge into the northern perimeter drainage system. No process equipment was observed during the ANL inspection.

Two geophysical investigations were performed by ANL in the vicinity of Building E5032. An initial geophysical investigation was conducted in April 1991, followed by a resurvey in 1994. Results from the 1991 surveys reveal geophysical signatures interpreted to be caused by the presence of a large iron tank or vault. This feature may be the remnant of Building 91. Magnetic anomalies mostly north of the main building appear to be caused by buried tanks. The January 1994 geophysical investigation indicates an anomaly extending across the survey area just a few feet north of Building E5032; this feature is interpreted to be a sanitary sewer line. The shape and strength of a conductivity anomaly indicate the presence of a buried drain line connecting the sump works and the perimeter drainage ditch. The study area south of the building was limited for the geophysical investigation. An extension of the study area to the south might have revealed more anomalies extending from the four sumps south of the building.

An investigation of hazardous materials facilities (HMFs) indicates that the six HMFs located at Building E5032 (described in the Consent Order between APG and the Waste Management Administration, Maryland Department of the Environment) were regulated not under the Underground Storage Tank (UST) Program, but under the Clean Water Act because they discharged to a sewer line or creek. Seven exterior and two interior sumps are associated with Building E5032. Two of the exterior sumps are located adjacent to the building on the west side, four are located next to the four bays on the south side, and one is located in the northeast corner of the building. These sumps are designated solid waste management units (SWMUs). Any further activity related to these sumps should follow the Comprehensive Environmental Response, Compensation, and Liability Act (CERCLA) remedial investigation guidelines.

On the basis of information collected and reviewed for Building E5032, it is the authors' judgment that the geophysical surveys indicate some anomalies in the vicinity of Building E5032 that warrant further investigation and evaluation. Asbestos testing is recommended for the various suspect asbestos-containing piping insulation observed inside Building E5032. An air quality monitoring program should be conducted to establish potential sources of air contamination. 


\section{Introduction}

The U.S. Army Aberdeen Proving Ground (APG) commissioned Argonne National Laboratory (ANL) to conduct a contamination source review to identify and define areas of toxic or hazardous contaminants and to assess the physical condition and accessibility at various APG buildings. The information obtained from this review may be used to assist the U.S. Army in planning for the future use or disposition of this building. The contamination source review consisted of the following tasks: historical records search, physical inspection, photographic documentation, geophysical investigation, and review of available records regarding underground storage tanks associated with this building. This report provides the results of the contamination source review for Building E5032.

Located on Chesapeake Bay in Harford and Baltimore counties, Maryland, APG occupies approximately 30,000 acres. The facility is divided into the Aberdeen and Edgewood areas (Figure 1). Building E5032 is located near Canal Creek in the north-central part of APG's Edgewood Area. This building is at the northwest corner of the intersection of Hoadley Road and Magnolia Road. The primary mission at APG has been the testing and evaluation of U.S. Army warfare materials. Since its beginning in 1917, the Edgewood Area of APG has been the principal location for chemical warfare agent research, development, and testing in the United States. APG was also used for producing chemical warfare agents during both world wars and has been a center for the storage of chemical warfare material (Nemeth 1989).

Many of the APG facilities constructed between 1917 and the 1960s are no longer used because of obsolescence and their poor state of repair. Because many of these buildings were used for research, development, testing, and/or pilot-scale production of chemical warfare agents and other military substances (such as incendiary materials or munitions containing these materials), the potential exists for portions of the buildings to be contaminated with these substances, their degradation products, and other laboratory or industrial chemicals. These buildings, and associated structures or appurtenances (e.g., underground or aboveground storage tanks, pipes, sumps), may contribute to environmental concerns at APG. 


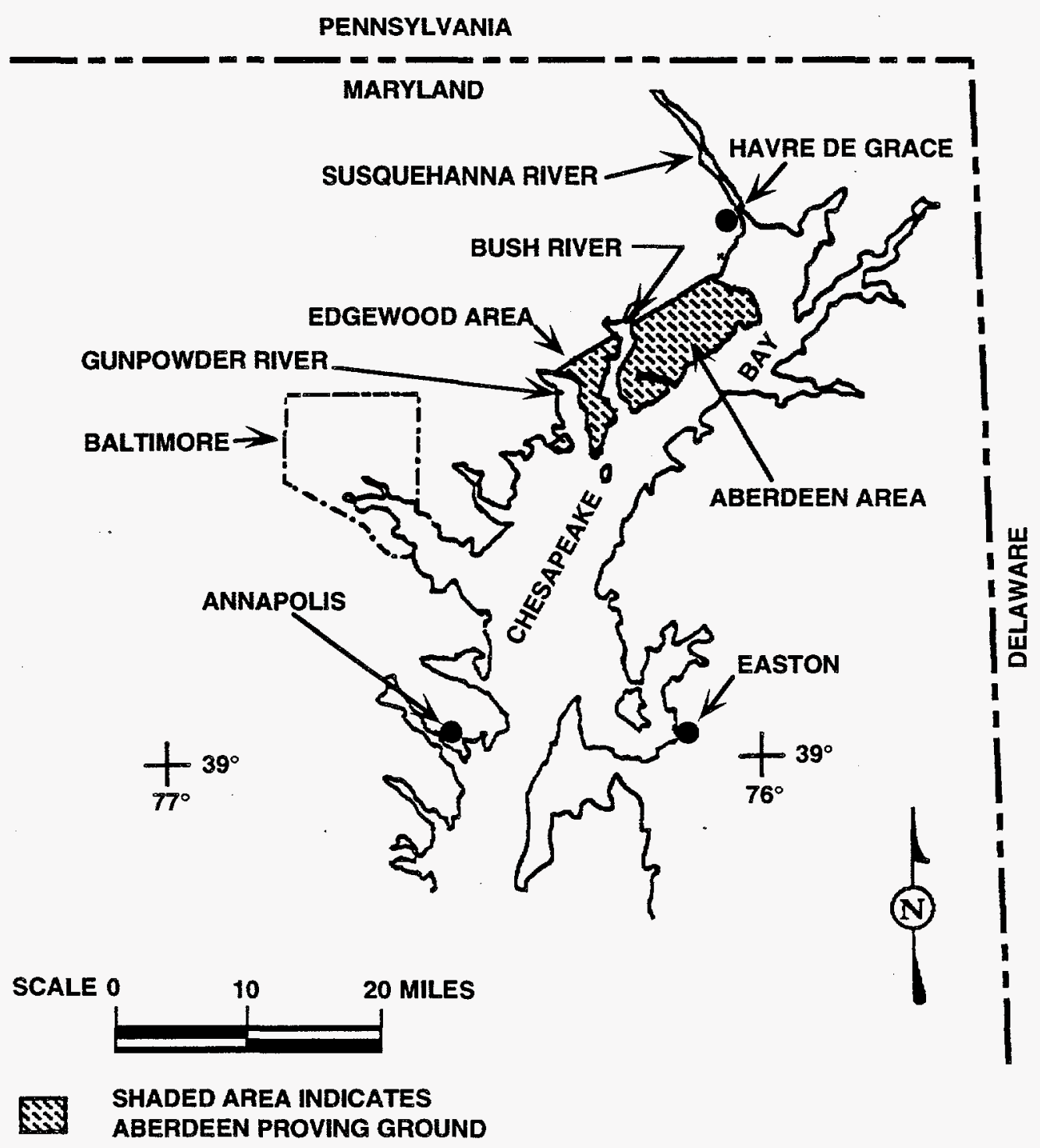

FIGURE 1 Map of Aberdeen Proving Ground Location 


\section{Methodology}

Before the building inspection, ANL personnel made a preliminary site visit to locate the building and obtain building records from APG, identify potential issues to be addressed in the health and safety plan, résolve any access restriction issues, and identify required support services.

Photographs were taken of the building's exterior and interior surfaces during the building inspection in November 1994. The photographs followed a set sequence whenever possible. The exterior was photographed starting on the north side and continuing clockwise around the building; walls were photographed starting in the north or northwest corner of each room and continuing clockwise until reaching the starting point. The ceiling and floor of each room were also photographed.

Two geophysical investigations have been performed by ANL in the vicinity of Building E5032. An initial geophysical investigation was conducted in April 1991 (McGinnis and Miller 1991) followed by a resurvey investigation conducted in 1994 (Thompson et al. 1994). During the January 1994 geophysical investigation (Thompson et al: 1994), ANL used new instrumentation, including two types of electromagnetic induction instruments and a cesium vapor magnetometer, to identify underground structures located near Building E5032.

No air quality information for Building E5032 was available during the preparation of this report.

ANL conducted field investigations of hazardous materials facilities (HMF) located in and around buildings at APG, including Building 5032 (Cobo 1994). The field investigations consisted of reviewing historical documentation of HMFs, identifying HMFs, and sampling liquids present in the HMFs for each of the buildings included in the survey.

Detailed descriptions of the methodology used for the HMF investigation are provided in the appendix to this report. 


\section{Historical Record Search}

Building E5032 (APG designation), originally known as Building 99 under the old APG numbering system, is located at the northwest corner of the intersection of Hoadley Road and Magnolia Road in the Edgewood Area of APG (Nemeth 1989).

According to historical records, Building E5032 was constructed during World War I (1918) as an incendiary bomb filling plant. Building 91, which no longer exists, was located near Building E5032 and was a covered concrete pit that contained storage tanks for chemicals used in the incendiary filling plant in Building E5032 (Nemeth 1989). Plans had been made to fill $75-\mathrm{mm}$ shells with titanium tetrachloride (smoke), but they were canceled before work on this project could begin. During the 1920s and 1930s, Building E5032 was maintained as a filling facility; incendiary bombs were produced during at least a portion of these two decades.

Building E5032 was used during part of World War II as a pilot plant for the development of a dry white phosphorus filling process (Nemeth 1989). The building has been used primarily for white phosphorus filling pilot studies during the period since World War II. The white phosphorus pilot filling studies were for both wet and dry methods. Most of the dry filling methods were developed in Building E5032 between 1965 and 1970.

Other filling operations in Building E5032 have included mustard during the period shortly after World War II and triethyl aluminum (TEA) during the late 1960s and early 1970s. A historical survey of the usage of Building E5032 (Yon et al. 1988) reported that the building had been used for white phosphorus/mustard mixture (HP) filling, GA filling (during the late 1940s), and thickening mustard. According to Yon et al. (1988), liquid waste was discharged to a chemical/storm sewer. During this period, the building was connected to the sanitary sewer system with one large and at least one small interior sump. There are seven sumps adjacent to the exterior of the building: two on the west elevation, four near the four cubicles on the south elevation, and one at the northeast corner of the building. All of these sumps are associated with the chemical sewer system and received most, if not all, of the production operation wastewater. The discharge from this system was into the east branch of Canal Creek; the discharge pipe was located southeast of Building E5032 (Nemeth 1989). 


\section{Building Description}

This section presents a detailed physical description of Building E5032 and the surrounding site as they appeared at the time of the ANL inspections in 1993 and 1994. The physical description includes an account of the condition of the exterior walls, the roof, and each interior room. No process equipment was observed during the ANL inspections.

\subsection{Site Description}

\subsubsection{Location}

Building E5032 is located near Canal Creek in the north-central part of the Edgewood Area of APG. The building is at the northwest corner of the intersection of Hoadley Road and Magnolia Road (Figure 2).

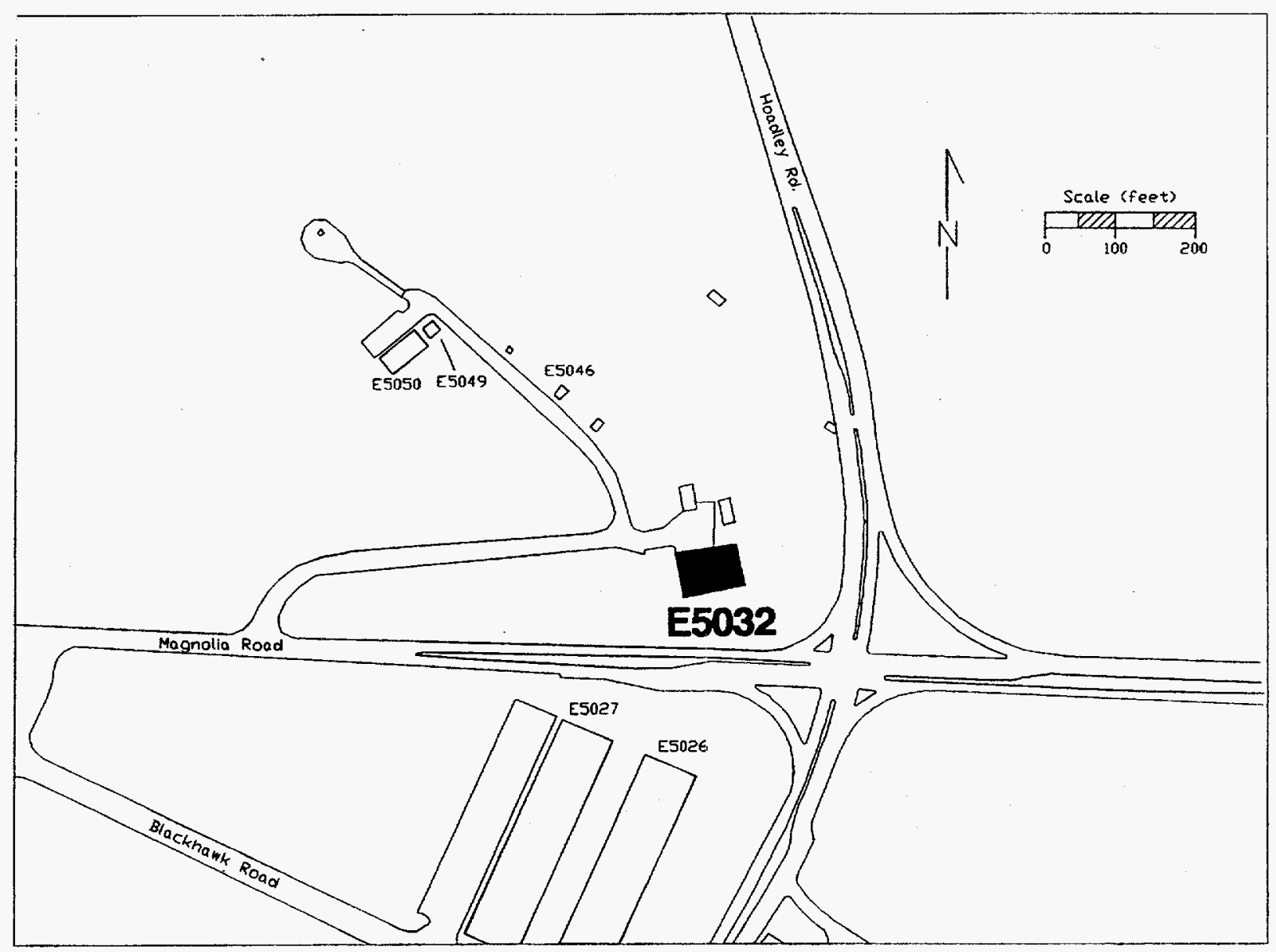

FIGURE 2 Map of Building E5032 Location 


\subsubsection{Proximity to Other Buildings}

The remains of two additional buildings are reportedly located in the survey area. Historical records indicate that a storage shack, Building T5033 (old number 99A), was approximately $50 \mathrm{ft}$ north of Building E5032. If still present, this structure would occupy the northwest corner of the parking apron adjacent to Building E5032. Another structure, Building 91 (old numbering system), was reported in the Resource Conservation and Recovery Act (RCRA) Facility Assessment to be near Building T5033 (Nemeth 1989). However, neither the date when Building 91 was demolished nor its exact location is known. Analysis of aerial photographs from 1957 shows a structure north of Building E5032; this building is interpreted to be Building T5033. None of the aerial photographs available to ANL show the Building 91 structure (Thompson et al. 1994).

\subsubsection{Building Structure}

Numerous exterior concrete pads, sumps, aprons, and drainage ditches (troughs) were found near Building E5032. The building shows evidence of several major modifications during its history. The main building is constructed of a vertical I-beam steel structure with steel roof trusses. The exterior of the main building is covered by corrugated sheet metal. Numerous holes of varying sizes indicate that piping once passed through the exterior walls of the building. An addition along the south side of the main building, constructed of cinder blocks, consists of four small cubicles. These cubicles are accessible only through exterior double doors located at the center of each cubicle. Outside of the cubicles, a concrete slab extends approximately $6 \mathrm{ft}$ to the south and $10 \mathrm{ft}$ to the west. A 6-in.-high concrete curb frames the concrete slab on the east and south edges. Figure 3 shows a plot plan of Building E5032 and its vicinity. Figure 4 shows a floor plan of Building E5032, developed at the time of ANL's inspections. Photographs of the building exterior are presented in Figure 5.

Building E5032 contains eight rooms, each designed to perform different functions required for munitions loading. The current configuration of Building E5032 (Figure 4) represents how the building appeared during its last operational periods, when it was used for loading white phosphorus and TEA. There are no records indicating the use of Building E5032 after 1974; it is assumed that the building has been out of service since that time. The level of deterioration in this building is consistent with this assumption. The building's structural systems (steel framework) are in relatively good condition, showing few signs of deterioration, fatigue, or failure. The exterior walls of the building (corrugated sheet metal) are severely deteriorated and, in some areas, have rusted through. The doors and windows of the building have also deteriorated. All of the windows are currently boarded over, and the building can be accessed only through the large rolling doors on the building's north side.

The interior walls and partitions of the buildings consist of two types: common wood framing with a finished gypsum board and multicelled ceramic construction building blocks. The 


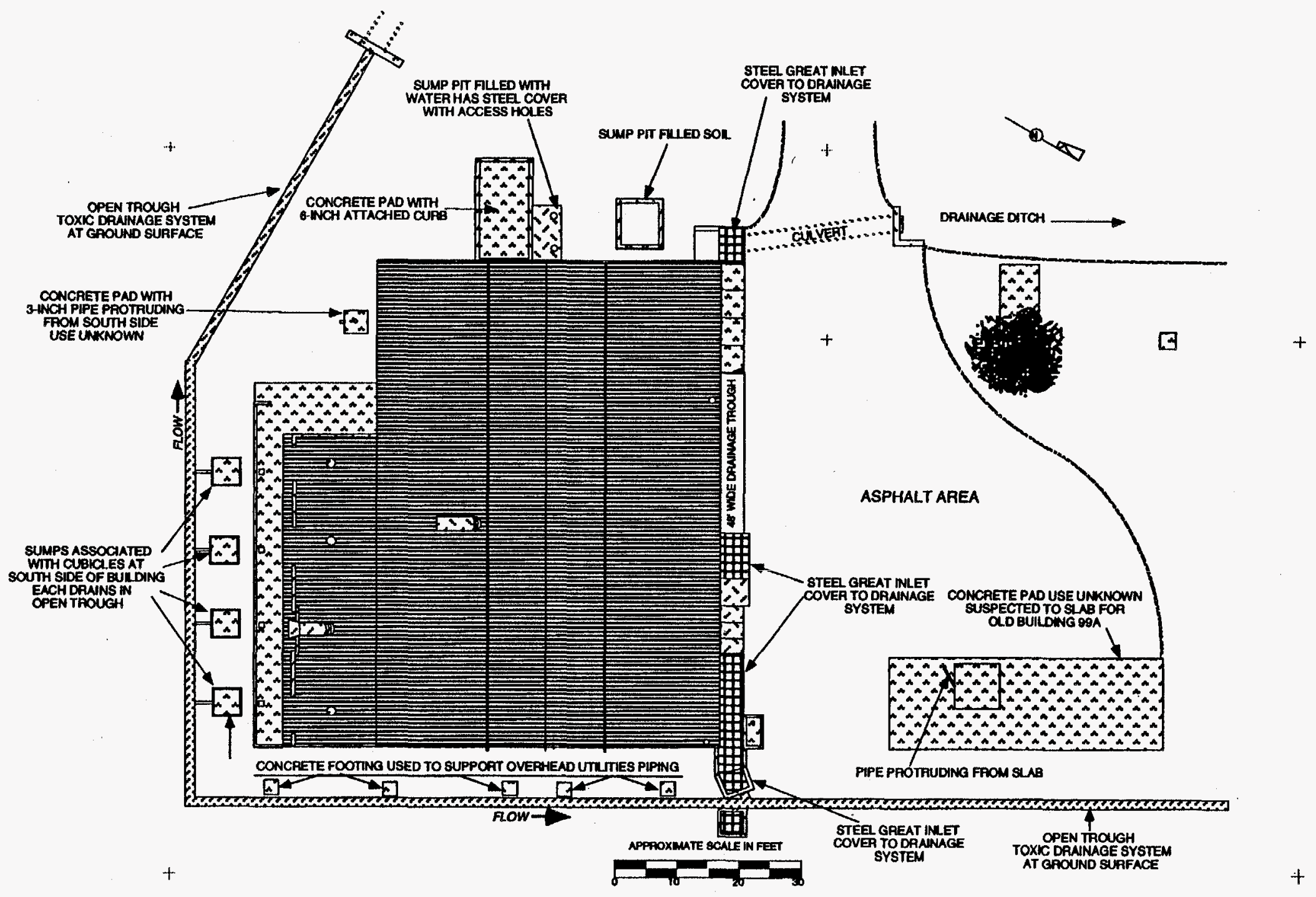

FIGURE 3 Building E5032 Plot Plan 


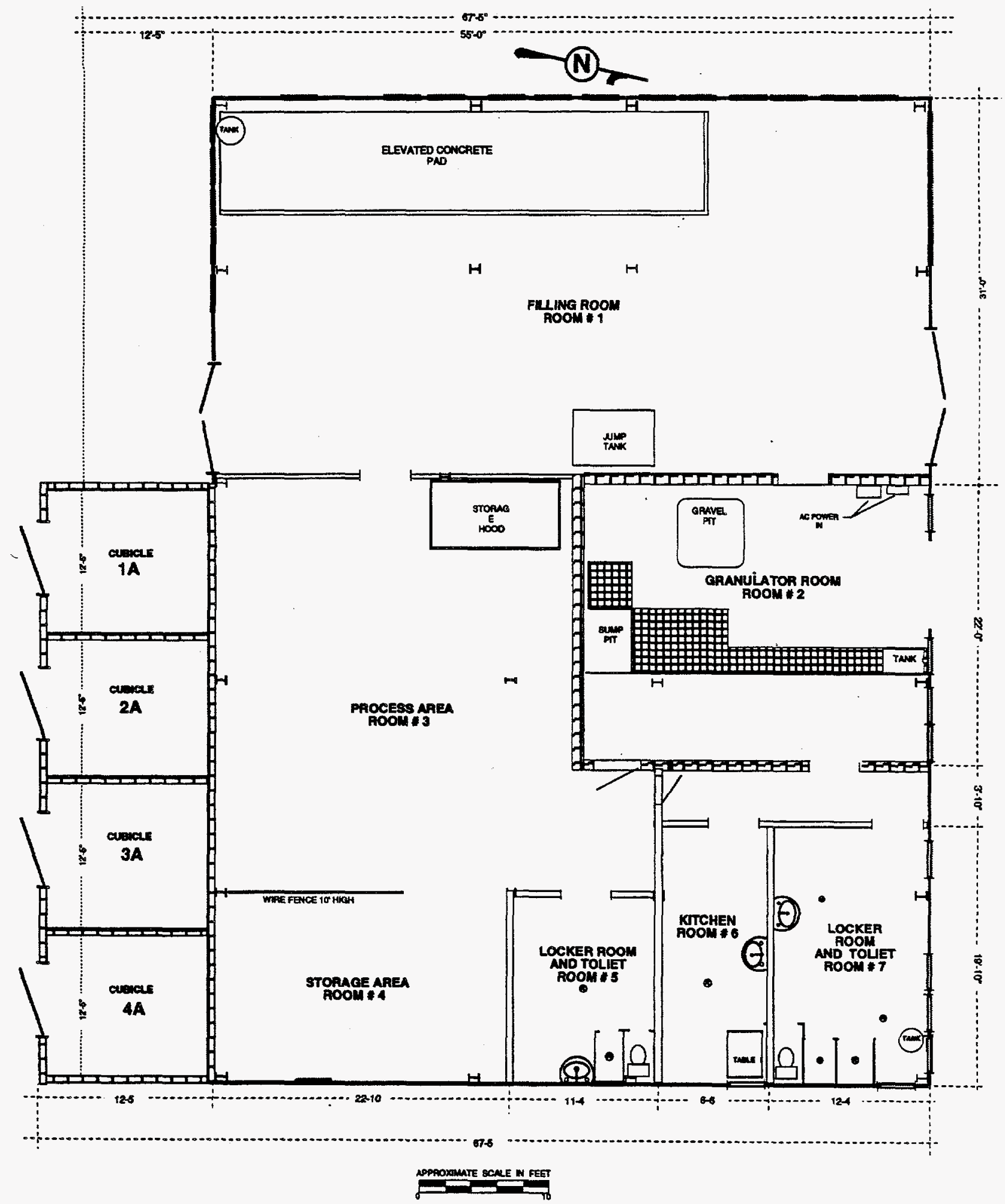

FIGURE 4 Building E5032 Floor Plan 

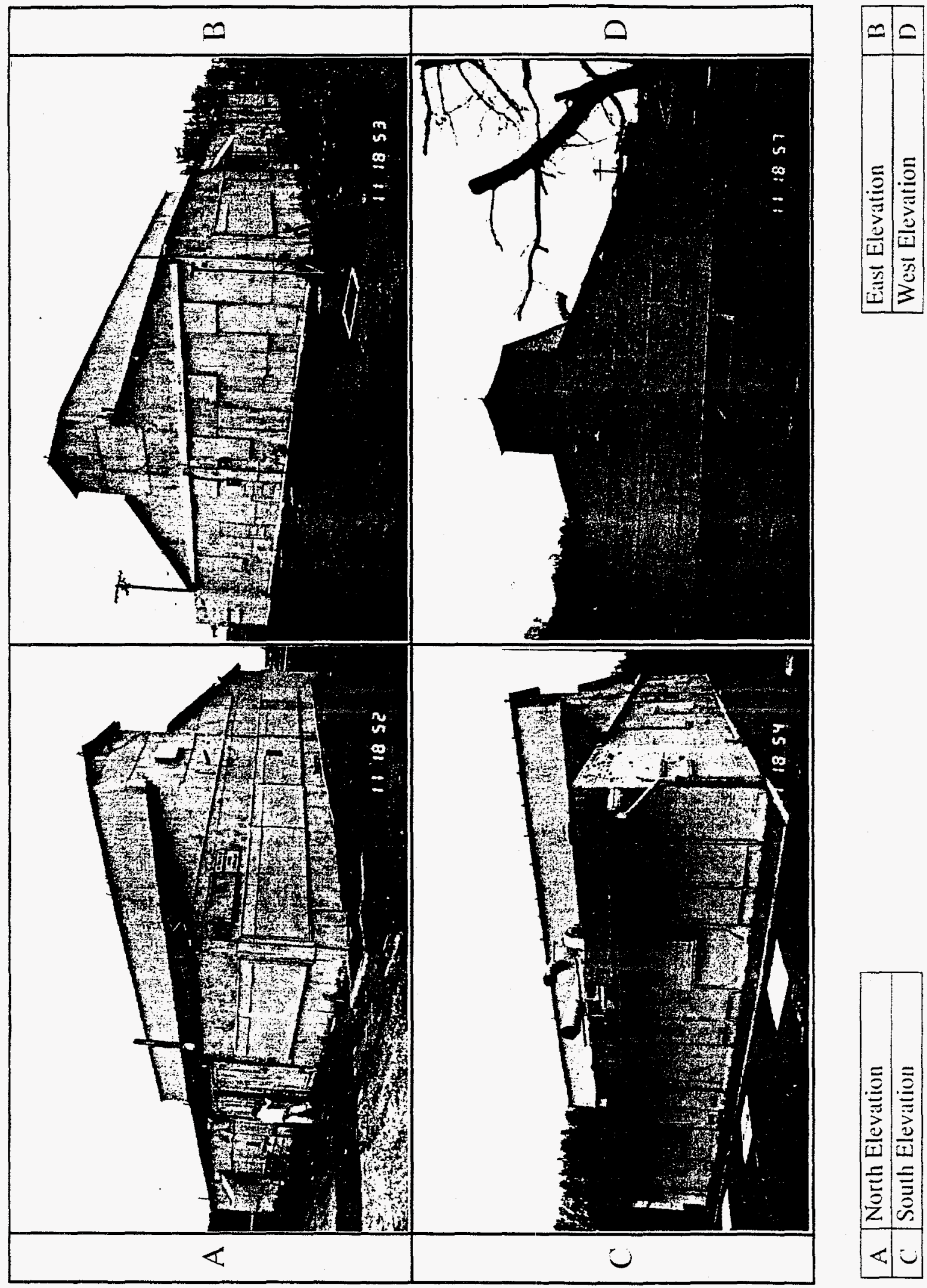

음

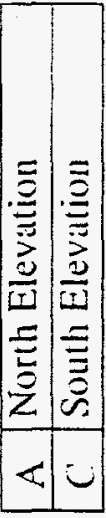

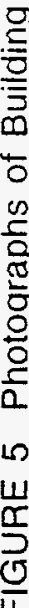


concrete blocks in Building E5032 are ridged on both sides to receive a plaster finish, but plaster was never applied. The fact that this type of block is used for an interior partition wall and that these walls were never finished is evidence that the building has undergone major modifications through the years. The floors of the building also show evidence of modification. Several areas of the concrete floor have been reinforced to support heavy equipment. In one portion of the building, a section of the floor has been removed and a large hole remains. In other areas of the building, 6-in.-thick concrete sills were added at the door thresholds, probably to provide containment for spills.

\subsubsection{Exterior Dimensions}

The main building measures $76 \mathrm{ft} 8 \mathrm{in}$. along the north wall and $55 \mathrm{ft}$ along the west wall. Each of the four cubicles that make up the addition at the east corner of the south wall is a $12-\mathrm{ft}$, 5 -in. square (Figure 4).

\subsubsection{Topography}

The contour of the ground surface surrounding Building E5032 is generally flat. A gentle slope away from the building at the south and east sides directs surface runoff toward two storm water drainage ditches: one on the east side of the building that runs in a north-south direction and another on the south side of the building that runs in an east-west direction.

\subsubsection{Vegetation in the Immediate Vicinity}

The area surrounding Building E5032 consists primarily of cut grass, which grows adjacent to the building on the east, south, and west sides. An asphalt parking lot lies between the grass and Building E5032 on the north side. A tree is present near the north side of Building E5032, and ivy climbs the exterior walls near the northeast corner of the building.

\subsubsection{External Aboveground Structures or Equipment}

Aerial photographs taken in 1963 show a large aboveground storage tank approximately $150 \mathrm{ft}$ to the north of Building E5032. This tank is no longer present and no record of its removal was discovered during the records search. The ANL geophysical survey conducted at this site also revealed evidence of this tank (see Section 5). 


\subsubsection{Connections with Adjacent Buildings}

Approximately $75 \mathrm{ft}$ to the north of Building E5032, ANL observed portions of an old concrete slab, believed to be the remains of Building 91. Building 91 is described in APG records as a covered concrete pit that housed chemical storage tanks, which were used to support the operations in Building E5032. Several pipes exit the ground near this concrete slab; these may be associated with underground chemical storage tanks still present at this location.

\subsubsection{Underground Structures}

Several pipes that exit the ground near the concrete slab north of the building may be associated with tanks still present at this location. The geophysical survey for Building E5032 indicated that a number of buried tanks may be present beneath the parking lot.

A vaulted space is located beneath the floor of room 2 (see Section 4.9.6). The extent of this space, which is accessible through a series of metal grids on the floor, is unknown.

\subsubsection{Surface Drainage System}

See Section 4.1.5

\subsubsection{Utility Access Points}

An exterior sump is connected by piping to each of the four small cubicles attached to the south side of the main building. The sumps are connected to a concrete-lined, open sewer trough that encircles the east and south sides of the main building. This open sewer trough drains into an underground storm sewer that flows westward out of the study area.

Located approximately in the center of the west elevation of Building E5032 is a rectangular concrete slab with an attached 6-in.-high concrete curb along its perimeter. This slab, which measures approximately $8 \mathrm{ft}$ wide by $20 \mathrm{ft}$ long, is attached directly to the main building. A waste water sump with a diamond plate steel cover is adjacent to the north side of the slab. Located between this sump and the northwest corner of the building are the remains of an underground concrete structure. The only visual evidence of this structure are the exposed top edges of the vertical walls. The interior of this rectangular structure has been filled in with soil. The interior edges of the perimeter walls are fitted with imbedded steel angle.

An underground sump extends across the entire north side of the building. ANL observed evidence that the design and construction of this sump system were not uniform. Several 
different types of materials are incorporated into the system; the dimensions are very irregular; and the top of the sump system is covered with an assortment of materials, including slabs of concrete; plate steel, and metal grates. Piping of varying sizes provided drainage from the building into this sump system. Most of these pipes have been disconnected from their sources, most likely when the process equipment was removed from Building E5032. At the time of this inspection, the sump was filled with water. A healthy growth of algae was observed in the sumps that were inspected; a frog was living in one of the sumps.

A series of concrete footing blocks measuring approximately $2 \mathrm{ft}$ square are located to the east of Building E5032. The concrete blocks are approximately 10 to $12 \mathrm{ft}$ apart and are arranged in a row that is parallel to and approximately $8 \mathrm{ft}$ from the east side of the building. The lined waste water trench that runs south of the building continues adjacent to the row of concrete footing blocks.

The utilities that were formerly connected to the process equipment have been disconnected and, in some cases, cut. No equipment was found in Building E5032. There are no lock out or tag out labels on any of the disconnected utility lines or pipes. Partial sections of disconnected overhead stainless steel duct work are hanging from the ceiling along with electrical wire and numerous pipes.

\subsubsection{Exterior Piping}

Most of the remaining piping in Building E5032 is associated with the steam heating system. These pipes are covered with deteriorating, suspect asbestos-containing insulation. No asbestos testing was conducted. Other pipes are associated with a system that delivered compressed air throughout the building. Also remaining in the building are the drinking water system and its accompanying drain system. Most of the piping in the building has been disconnected; some of the remaining piping may have been associated with the filling process equipment. No testing of the piping systems was conducted.

\subsubsection{Nearby Roads and Sidewalks}

Building E5032 is located at the northwest corner of the intersection of Magnolia Road and Hoadley Road. The geophysical survey indicated that railroad tracks may have passed very close to Building E5032 on the northwest and northeast. Portions of these tracks were visible at the ground surface west of the study area.

An asphalt parking area located beyond the north perimeter drainage ditch extends north away from the building for approximately $60-70 \mathrm{ft}$. 


\subsection{North Exterior Elevation}

\subsubsection{Dimensions}

The north exterior wall of Building E5032 was $76 \mathrm{ft} 8 \mathrm{in}$. in length (Figure 6). The highest point of the north elevation is $25 \mathrm{ft}$.

\subsubsection{Construction Materials}

The siding is made of corrugated metal sheeting.

\subsubsection{Doors and Windows}

One single door and two double doors are on the north elevation. There are 12 windows, all boarded over with plywood, on the north elevation.

\subsubsection{Piping}

Remnants of pipes were observed along the north elevation (Figure 6).

\subsubsection{Utility Connections}

None.

\subsubsection{External Equipment or Structures}

One concrete pad located on the north elevation may be associated with the old Building 99. A pipe protrudes from the pad.

\subsubsection{Vegetation}

Grass and weeds are growing up from cracks in the pavement north of the building. 

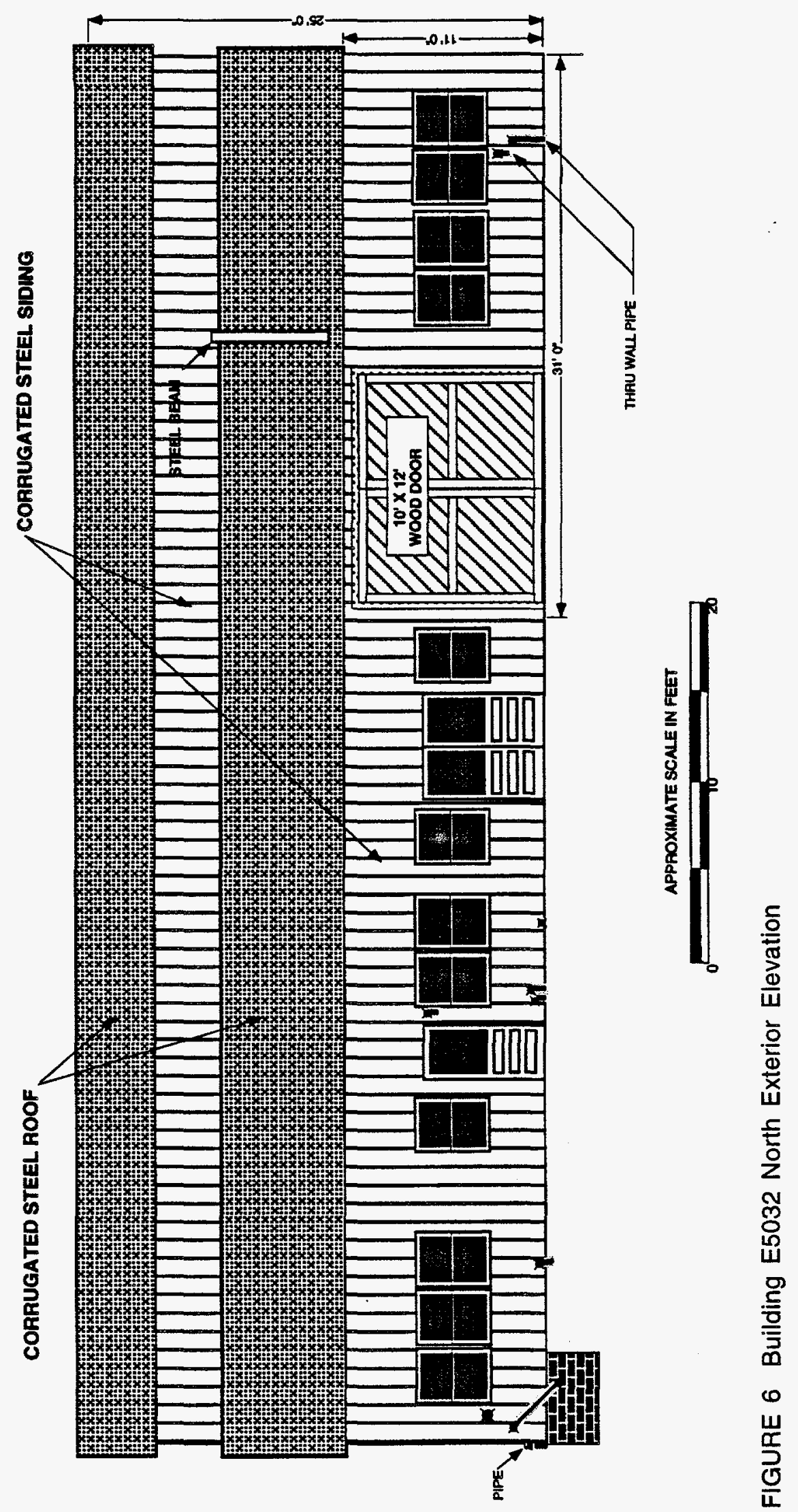


\subsubsection{Overall Condition}

The north exterior wall of the building (corrugated metal sheet) is severely deteriorated and, in some areas, rusted through. The doors and windows have also deteriorated.

\subsection{East Exterior Elevation}

\subsubsection{Dimensions}

The east exterior wall of Building E5032 measures $55 \mathrm{ft}$ in length and $25 \mathrm{ft}$ high at the highest point (Figure 7). The east exterior wall of the offset cubicle is $12 \mathrm{ft} 5 \mathrm{in}$. long and $11 \mathrm{ft}$ high.

\subsubsection{Construction Materials}

The siding is made of corrugated metal sheeting. The offset cubicles are constructed of brick.

\subsubsection{Doors and Windows}

Four single doors and seven windows are located on the east elevation. All of the windows and doors are boarded over with plywood.

\subsubsection{Piping}

Remnants of pipes were observed on the east elevation (Figure 7).

\subsubsection{Utility Connections}

None. 

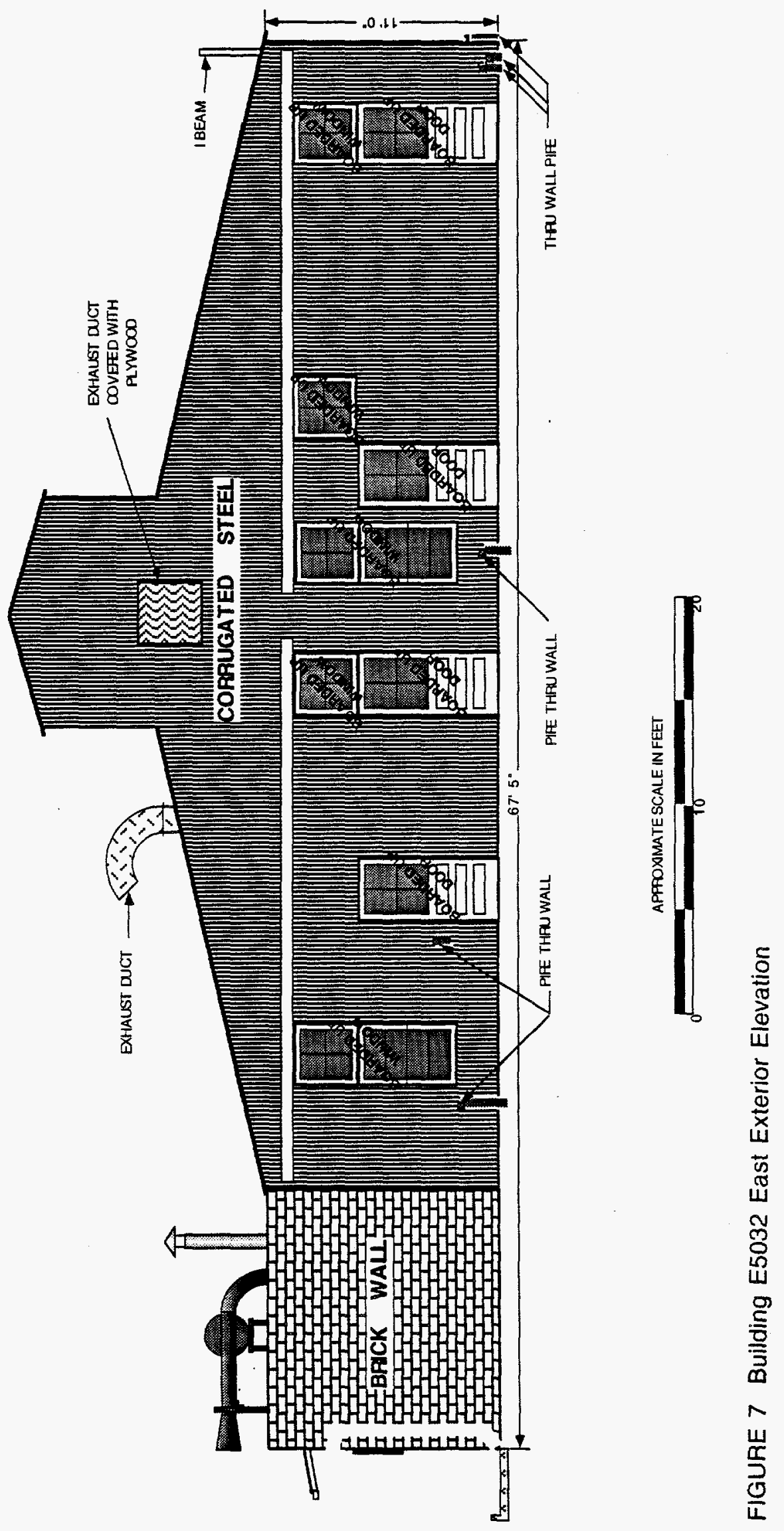


\subsubsection{External Equipment or Structures}

Plywood covers an exhaust duct on the east elevation.

\subsubsection{Vegetation}

The vegetation east of Building E5032 consists of grass and weeds.

\subsubsection{Overall Condition}

The east exterior wall of the building (corrugated metal sheeting) is severely deteriorated and, in some areas, rusted through. The doors and windows have also deteriorated.

\subsection{South Exterior Elevation}

\subsubsection{Dimensions}

The south exterior wall of Building E5032 measures $76 \mathrm{ft} 8 \mathrm{in}$. long and $25 \mathrm{ft}$ high at the highest point (Figure 8). The cubicles together measure $49 \mathrm{ft} 8 \mathrm{in}$. long and $11 \mathrm{ft} \mathrm{high}$.

\subsubsection{Construction Materials}

The siding is made of corrugated metal sheeting. The offset cubicles are constructed of brick.

\subsubsection{Doors and Windows}

Four double steel doors and one double wood door are located on the south elevation. There are five windows boarded over with plywood on the south elevation.

\subsubsection{Piping}

Remnants of pipes were observed on the south elevation (Figure 8). 


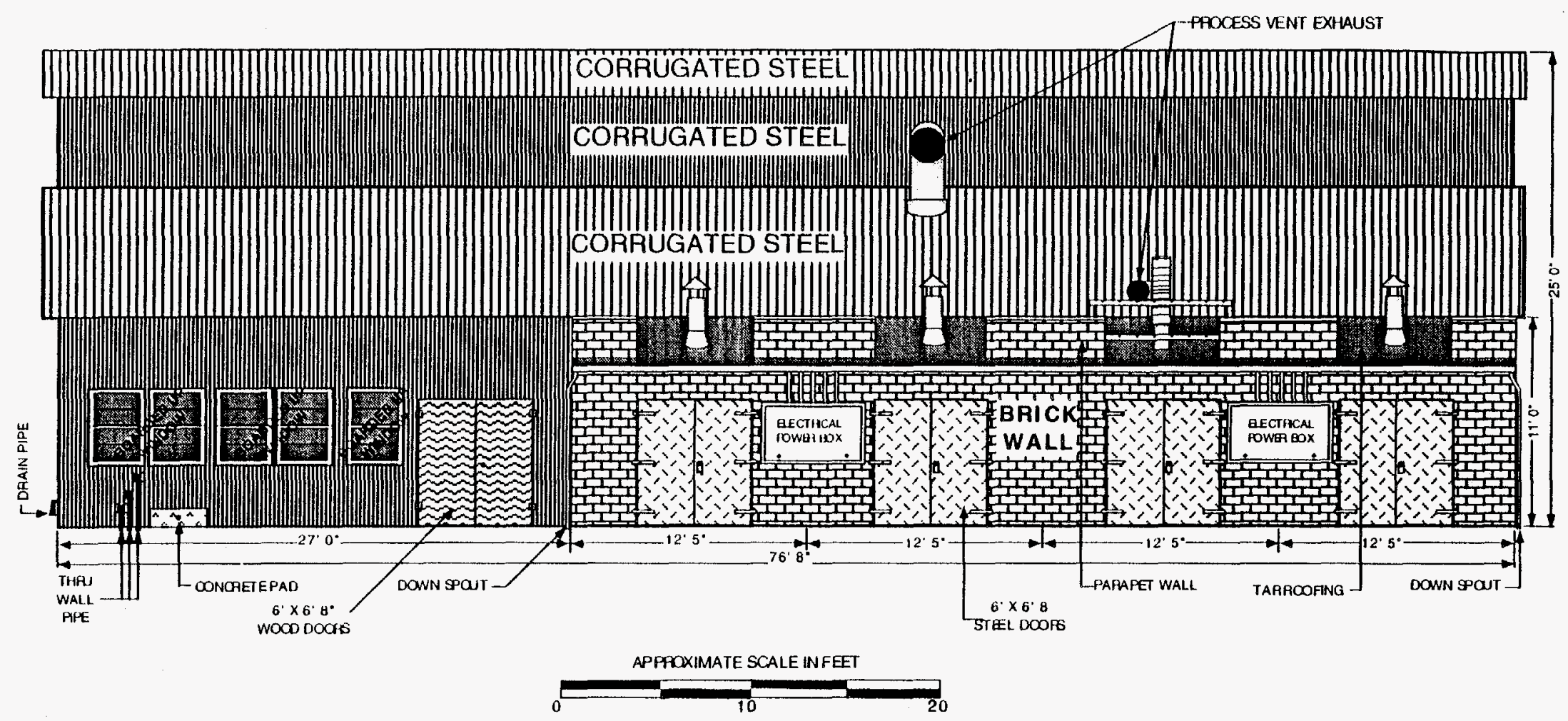

FIGURE 8 Building E5032 South Exterior Elevation 


\subsubsection{Utility Connections}

Two electrical power boxes containing switch controls for the building are located on the south elevation.

\subsubsection{External Equipment or Structures}

A concrete pad and two process exhaust ducts were observed.

\subsubsection{Vegetation}

The vegetation south of Building E5032 consists of grass and weeds.

\subsubsection{Overall Condition}

The south exterior wall of the building (corrugated metal sheeting) is severely deteriorated and, in some areas, rusted through. The doors and windows have also deteriorated.

\subsection{West Exterior Elevation}

\subsubsection{Dimensions}

The west exterior wall of Building E5032 measures $55 \mathrm{ft}$ long and $25 \mathrm{ft}$ high at the highest point (Figure 9). Each of the cubicles is $12 \mathrm{ft} 5 \mathrm{in}$. long and $11 \mathrm{ft} \mathrm{high}$.

\subsubsection{Construction Materials}

The siding is made of corrugated metal sheeting. The offset cubicles are constructed of brick. 

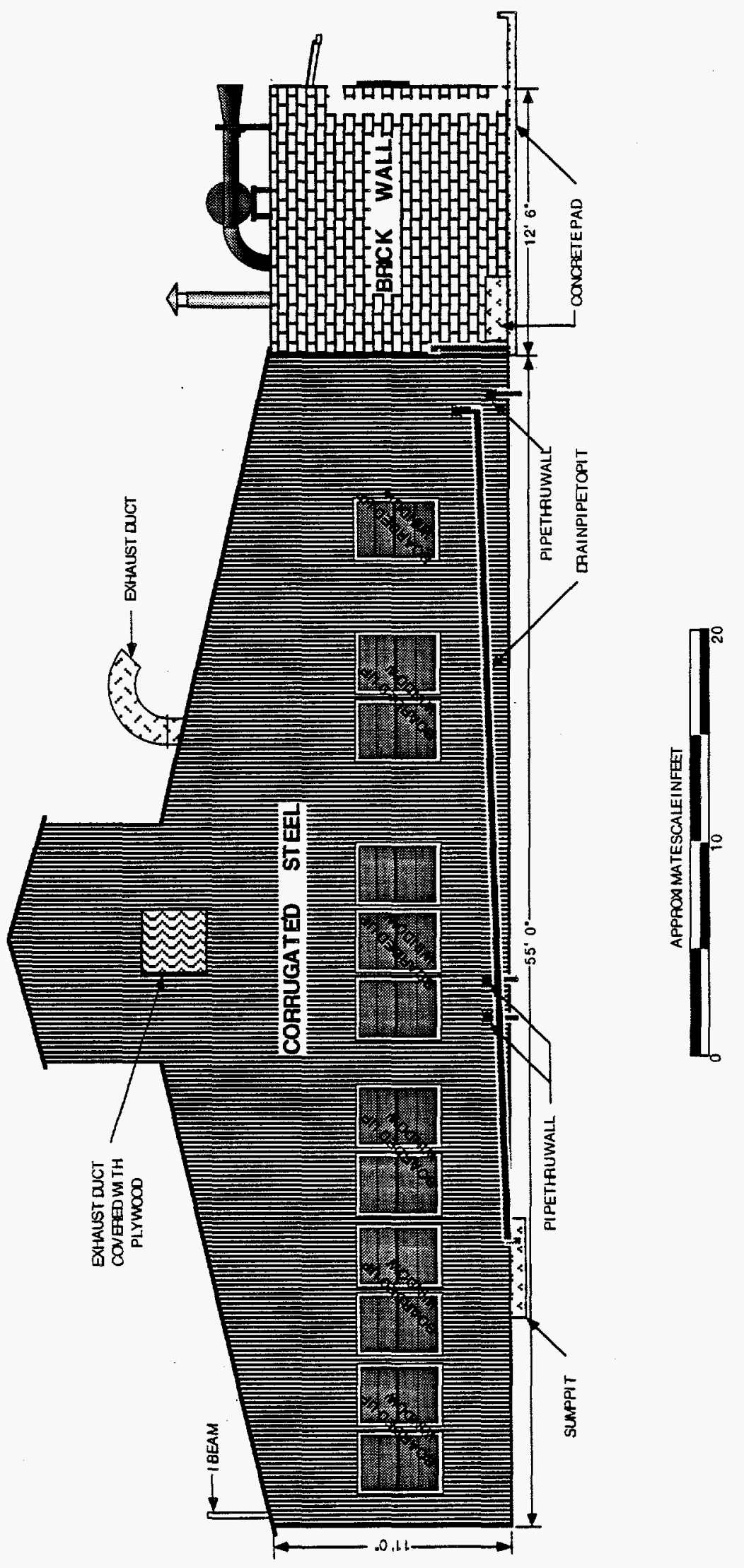

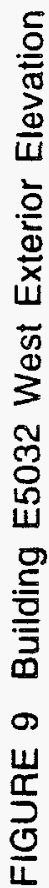




\subsubsection{Doors and Windows}

Twelve windows boarded over with plywood are located on the west elevation. There are no doors.

\subsubsection{Piping}

One drainage pipe leads to the sump pit. Other remnants of pipe were also observed (see Figure 9).

\subsubsection{Utility Connections}

None.

\subsubsection{External Equipment or Structures} elevation.

A sump pit, a concrete pad, and a plywood-covered exhaust duct are located on the west

\subsubsection{Vegetation}

The area west of Building E5032 is covered by grass and weeds.

\subsubsection{Overall Condition}

The west exterior wall of the building (corrugated metal sheeting) is severely deteriorated and, in some areas, rusted through. The windows have also deteriorated.

\subsection{Roof}

\subsubsection{Type and Dimensions}

Building E5032 has a sloping roof measuring $76 \mathrm{ft} 8 \mathrm{in}$. long by $55 \mathrm{ft}$ wide. 


\subsubsection{Height}

The highest point of the roof is $25 \mathrm{ft}$ above the foundation.

\subsubsection{Surface Materials}

The roof of Building E5032 is made of corrugated metal sheeting.

\subsubsection{Support System}

The roof of Building E5032 is supported by a structural steel framework.

\subsubsection{Condition}

No damage from leaking was observed in the roof at the time of the investigation.

\subsubsection{Equipment Located on Roof}

None.

\subsubsection{Chimneys, Roof Vents, or Vent Stacks}

An exhaust vent was observed on the roof (see Section 4.10.4).

\subsubsection{Piping}

None. 


\subsection{Interior Floor Plan}

\subsubsection{Room Numbers and Dimensions}

The main portion of Building E5032 contains eight rooms; four additional cubicle rooms are adjacent to the south side of the building. Room dimensions are listed below:

- Room 1: $55 \mathrm{ft}$ by $30 \mathrm{ft}$,

- Room 2: $26 \mathrm{ft} 3$ in. by $21 \mathrm{ft}$,

- Room 3: $28 \mathrm{ft} 3$ in. by $22 \mathrm{ft}$ plus an area $34 \mathrm{ft} 2$ in. by $8 \mathrm{ft} 8$ in.,

- Room 4: $22 \mathrm{ft}$ by $15 \mathrm{ft}$,

- Room 5: $14 \mathrm{ft} 7$ in. by $11 \mathrm{ft}$,

- Room 6: $18 \mathrm{ft} 10$ in. by $8 \mathrm{ft} 2$ in.,

- Room 7: $18 \mathrm{ft} 10$ in. by $12 \mathrm{ft}$, and

- Room 8: $20 \mathrm{ft} 10 \mathrm{in.}$ by $3 \mathrm{ft} 10 \mathrm{in}$.

Each of the four cubicles measures $12 \mathrm{ft} 5 \mathrm{in}$. by $12 \mathrm{ft} 5 \mathrm{in}$.

\subsubsection{Walls}

The interior walls of Building E5032 are constructed of drywall, clay tile, plywood, brick, plasterboard, wood, and chain-link fence. The cubicle walls are constructed of brick.

\subsubsection{Floor}

The floor is constructed of concrete and appeared to be in good condition at the time of the ANL inspection. 


\subsubsection{Floor Penetrations}

Building E5032 contains one vaulted area or sump pit (see Section 4.9.6), one area in which the concrete floor has been removed and the subgrade is exposed, a collection trench, and seven floor drains. Other penetrations may be associated with the sinks and toilets in the building.

\subsubsection{Interior Partitions}

See Section 4.7.1.

\subsubsection{Equipment or Supplies}

Equipment in Building E5032 at the time of this survey consisted of a jump tank, exhaust hoods, radiators, a water heater, a loading tray, space heaters, control gauges, electrical power boxes, conduit, a tank, lights, showers, sinks and toilets.

\subsection{Room 1}

\subsubsection{Walls}

The exterior walls of room 1 are constructed mainly of corrugated metal sheeting. Sections of the interior walls are constructed of drywall, plywood paneling, clay tile, plasterboard, and brick.

\subsubsection{Finish Materials}

Some walls in room 1 are covered by plaster. The walls are painted green and white.

\subsubsection{Piping}

The piping in room 1 is associated with different piping systems. Steam pipes and condenser drain pipes on the walls were used in conjunction with radiators located on the north and south walls. Water pipes along the walls are connected to sprinklers, a steel tank, and other equipment in the room. The steel tank, measuring approximately $6 \mathrm{ft}$ long, $4 \mathrm{ft}$ wide, and 
$2 \mathrm{ft} \mathrm{high,} \mathrm{is} \mathrm{labeled} \mathrm{as} \mathrm{a} \mathrm{"jump} \mathrm{tank"} \mathrm{on} \mathrm{a} \mathrm{wall} \mathrm{sign} \mathrm{above} \mathrm{it.} \mathrm{Exhaust} \mathrm{pipes} \mathrm{are} \mathrm{connected} \mathrm{to} \mathrm{the}$ exhaust system in the room. A pipe covered by suspect asbestos-containing insulation is connected to a hot water heater on the south wall of the building. Numerous other pipes are also present. See Figures 10 through 13 for the locations of these pipes.

\subsubsection{Equipment}

Radiator units are located on the north and south walls of the room. A steel jump tank is along the east wall, and a hot water heater is located near the southwest corner of the room. Electrical conduits are attached to the power boxes and electrical equipment in the room. Compressed air pipes attached to the steel girders run vertically along the wall.

The main exhaust system on the west wall of the building consists of several ducts and vents. A hood is cut out of the east wall with an exhaust duct extending vertically from the hood to the roof. A duct running east to west connects the exhaust equipment on the east wall with the main exhaust system.

\subsubsection{Doors and Windows}

The windows on the exterior walls are boarded over with plywood. The only doors accessible from the outside are on the north and south walls. The door on the south wall is boarded shut. See Figures 10 through 13 for wall materials, window locations, and door locations.

\subsubsection{Ceiling and Floor}

The ceiling is constructed of corrugated metal sheeting supported by a steel frame. The ceiling is painted white. The floor of room 1 is constructed of concrete. A collection trench is at the base of the west wall. No floor drains were observed.

Figures 14 and 15 provide photographs of the walls, ceiling, and floor of room 1. 

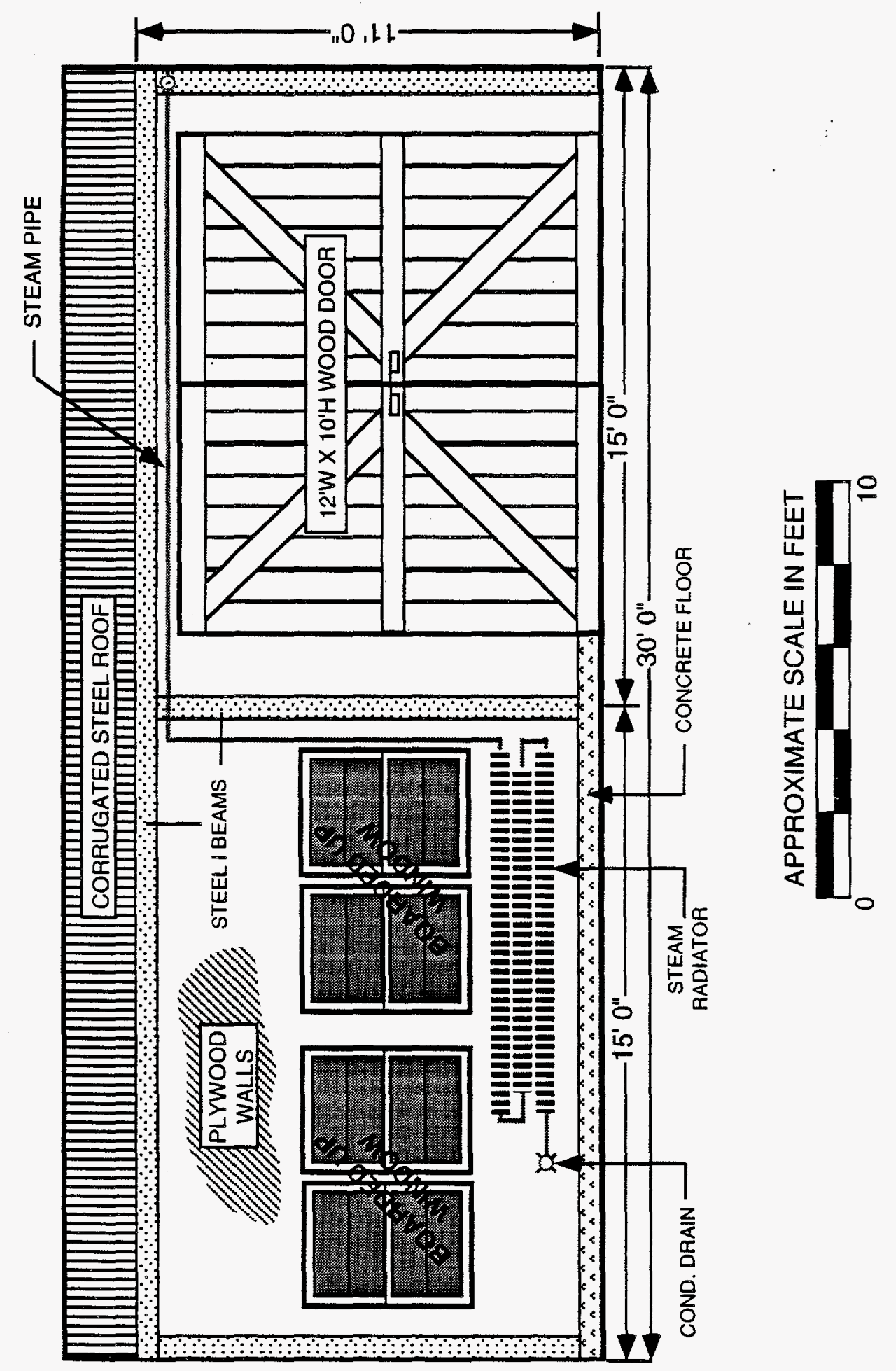

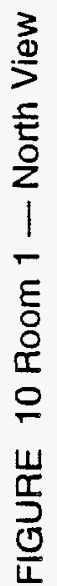




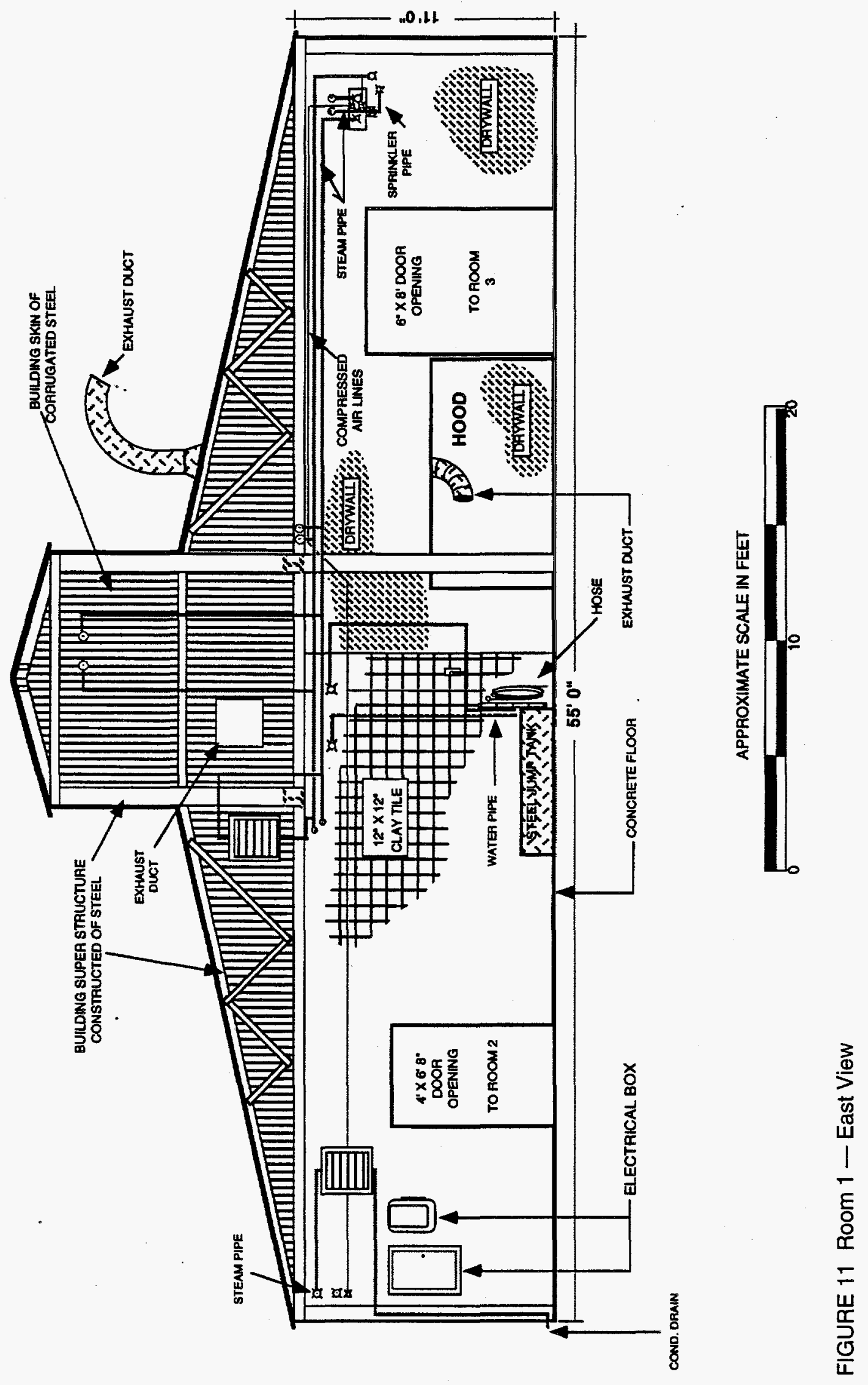



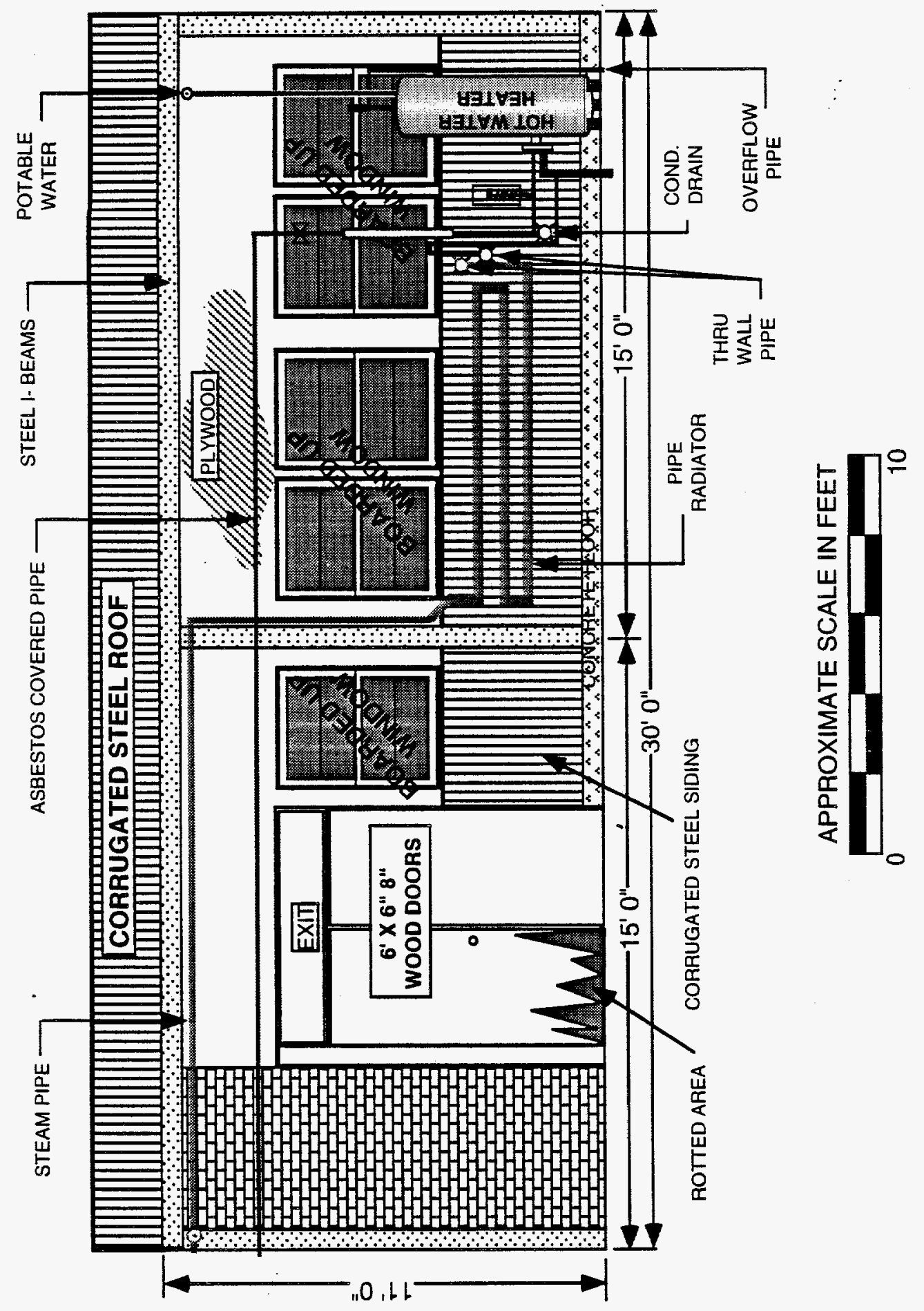

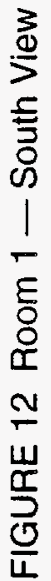




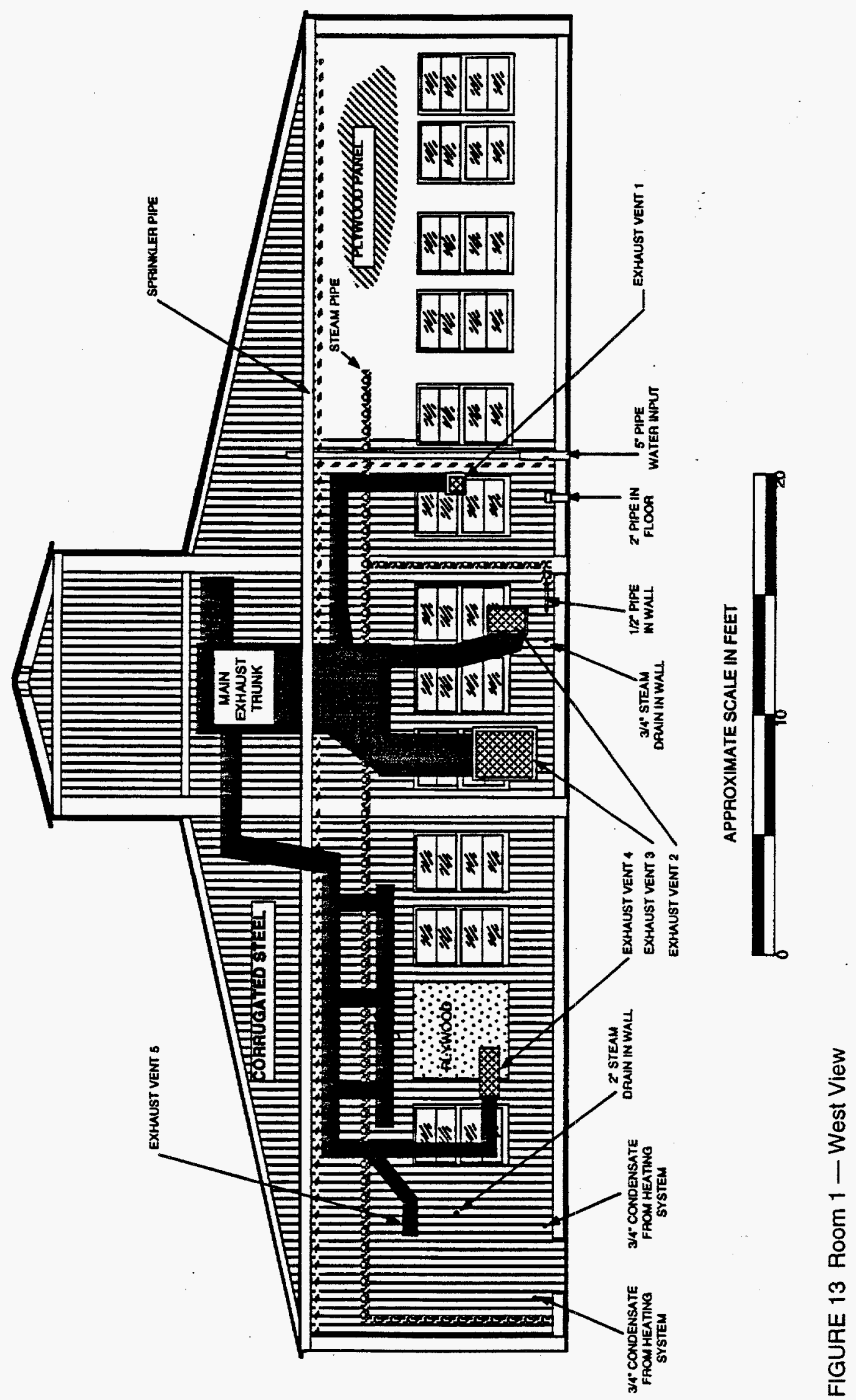



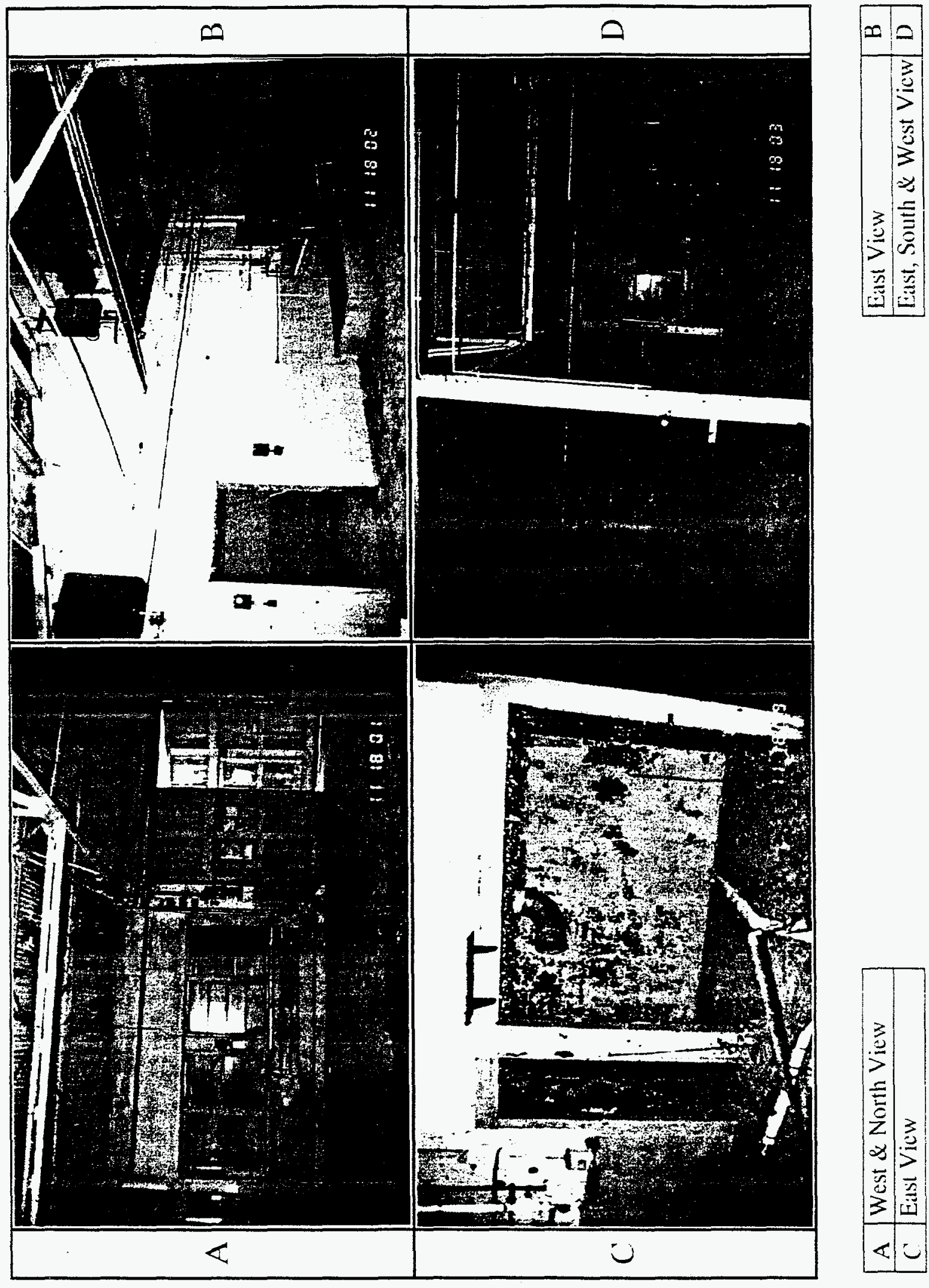

$\frac{\infty}{\bar{\pi}}$

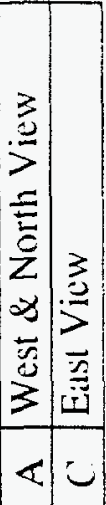

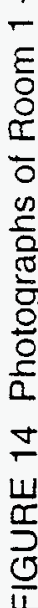



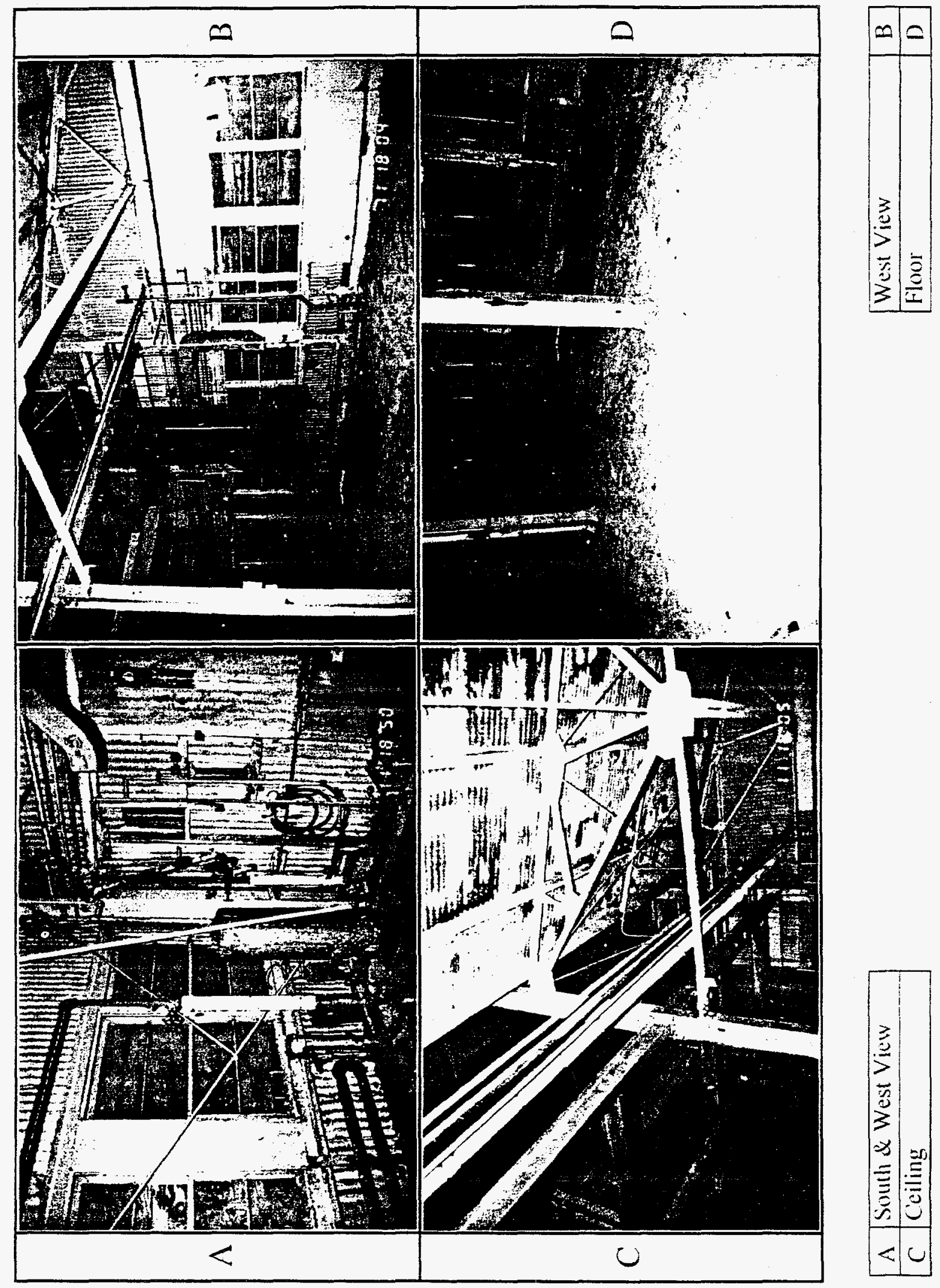

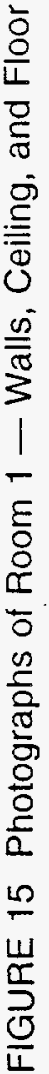




\subsection{Room 2}

\subsubsection{Walls}

The upper portion of the north wall is constructed of corrugated metal sheeting. The remainder of the north wall is constructed of metal and wood. The east, south, and west walls are constructed primarily of clay tile; part of the west wall is brick.

\subsubsection{Finish Materials}

Some plaster covers the west wall. The walls are painted green and white.

\subsubsection{Piping}

Numerous pipes run along each of the four walls. These pipes are covered by suspect asbestos-containing insulation. Pipes are also present in the collection trench. Figures 16 through 19 show the locations of the pipes.

\subsubsection{Equipment}

The north wall contains a loading tray and a steel support used for lifting the loading tray. A steam heater occupies the upper northeast corner of the room. Electrical switch boxes are located on the west wall and electrical conduit runs throughout. One exhaust hood is located on the north wall, and an exhaust vent is located on the south wall. The room also contains a space heater and several control gauges.

\subsubsection{Doors and Windows}

Two single doors occupy the east wall, and one double door and one doorway are on the west wall. Four windows and two doors to the outside (north wall) are boarded over with plywood. 


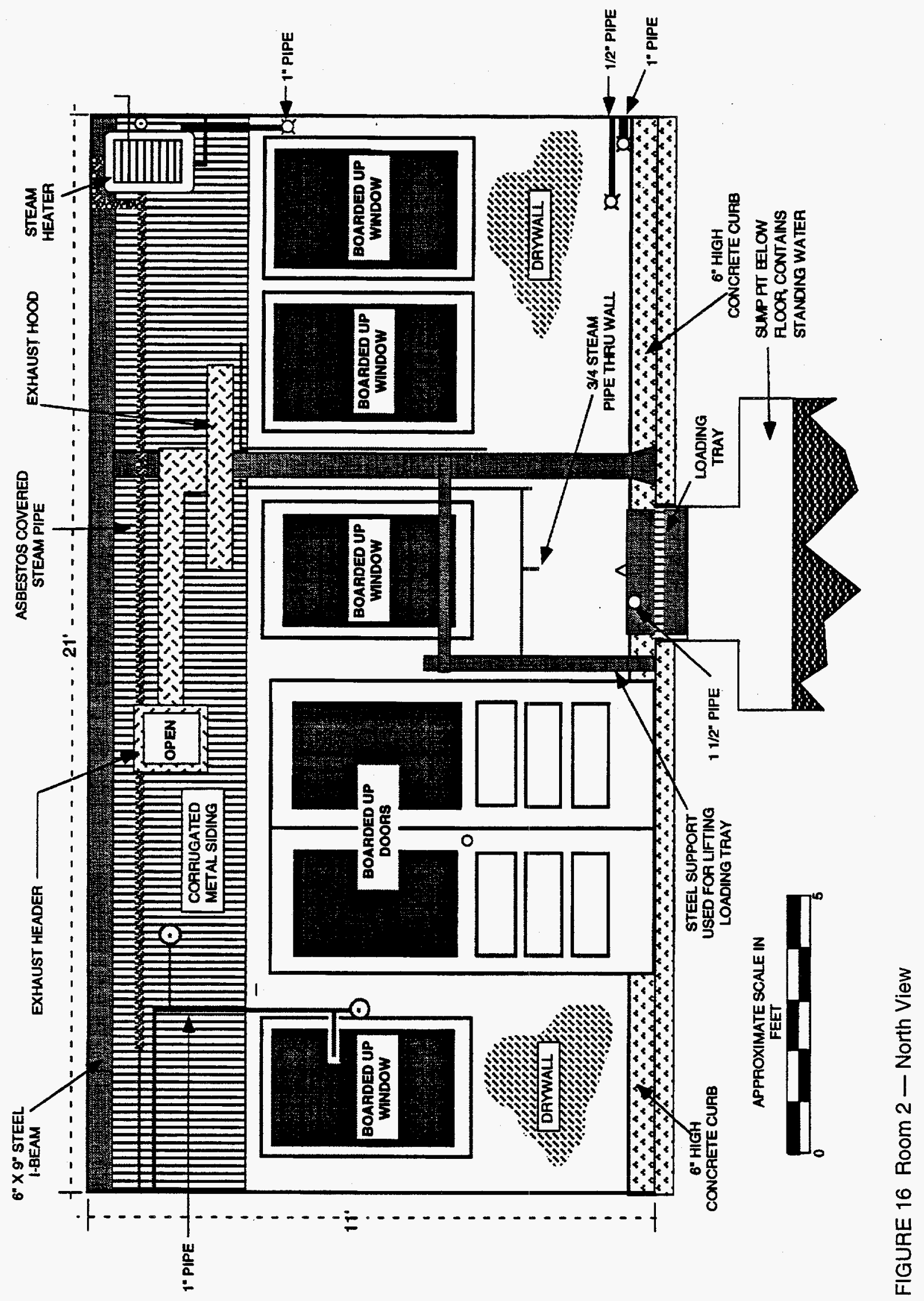




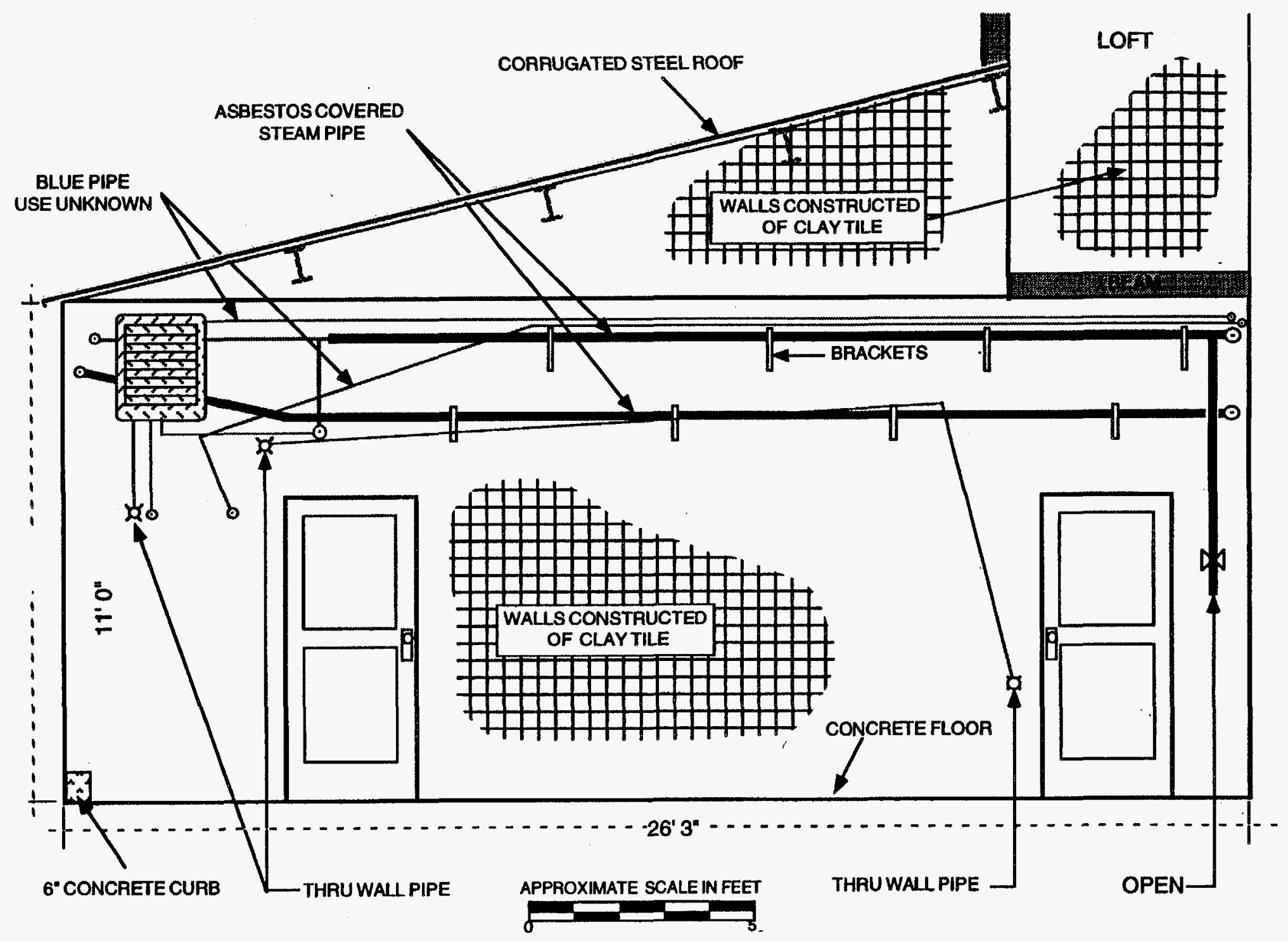

FIGURE 17 Room 2 - East View 


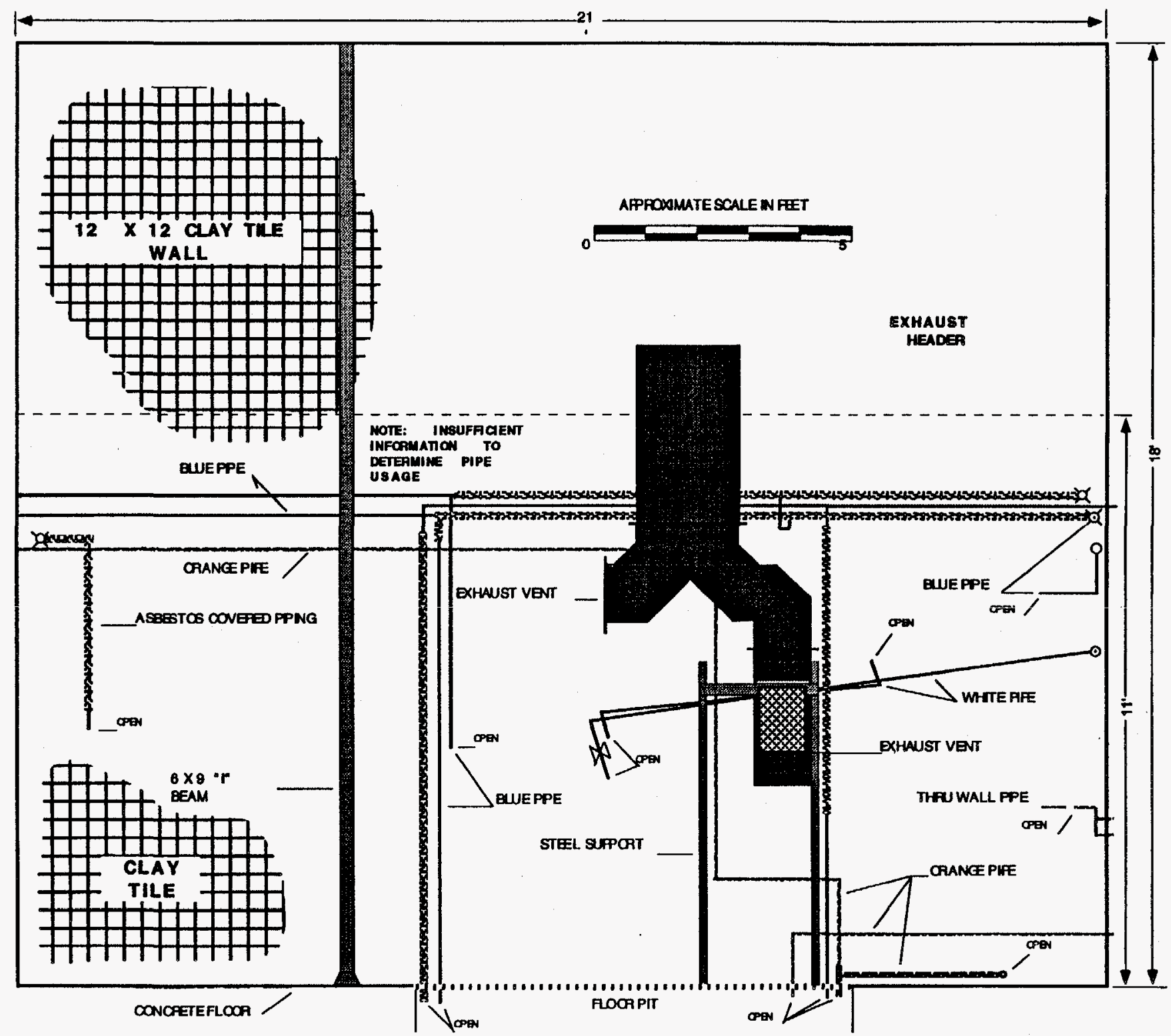

FIGURE 18 Room 2-South View 


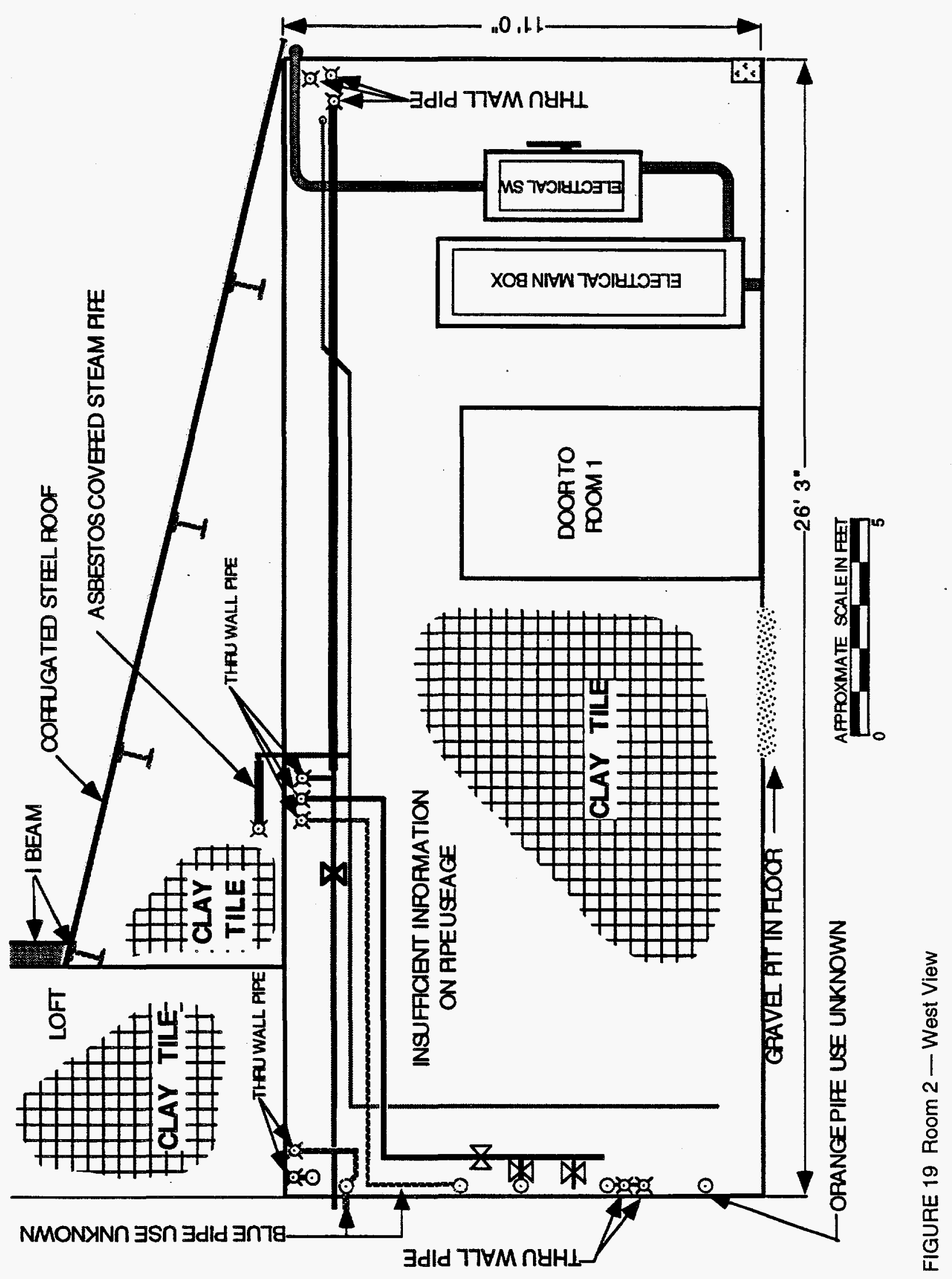




\subsubsection{Ceiling and Floor}

The ceiling is constructed of corrugated sheet metal supported by a steel structural frame. The ceiling is painted white. The floor is concrete bordered by a 6-in.-high wall footing on the north wall. An area of the concrete floor measuring approximately $3 \mathrm{ft}$ by $3 \mathrm{ft}$ has been removed, and subgrade soil is exposed.

A metal grate covers a vaulted area beneath the floor in this room. The metal grate extends from the center of the south wall to the center of the north wall. A metal tank approximately $2 \mathrm{ft}$ wide, $5 \mathrm{ft}$ long, and $18 \mathrm{in}$. high rests on the metal grate near the north wall. The extent, inlets, and outlets of the vaulted area are unknown. The area was filled with water to a depth approximately $2 \mathrm{ft}$ below the top of the concrete floor. This vaulted area may discharge into the northern perimeter drainage system.

Figures 20 and 21 provide photographs of the walls, ceiling, and floor of room 2.

\subsection{Room 3}

\subsubsection{Walls}

The exterior walls of this room are constructed of brick and metal. The interior walls are constructed of drywall, clay tile brick, wood, and 12-in. by 12-in. clay tile. A 10-ft-high wire fence separates rooms 3 and 4.

\subsubsection{Finish Materials}

The walls of room 3 are painted green and white.

\subsubsection{Piping}

Room 3 contains various piping systems; many of the pipes were observed on the south wall (see Figures 22 through 24). 


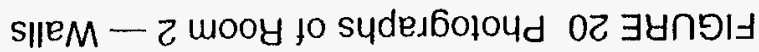

\begin{tabular}{|c|c|}
\hline G & M?! $\Lambda$ ISPM $X$ 4InOS \\
\hline$g$ & MPI \\
\hline
\end{tabular}

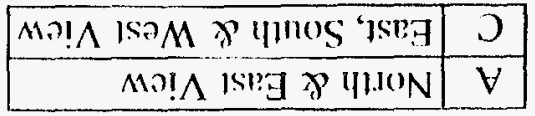
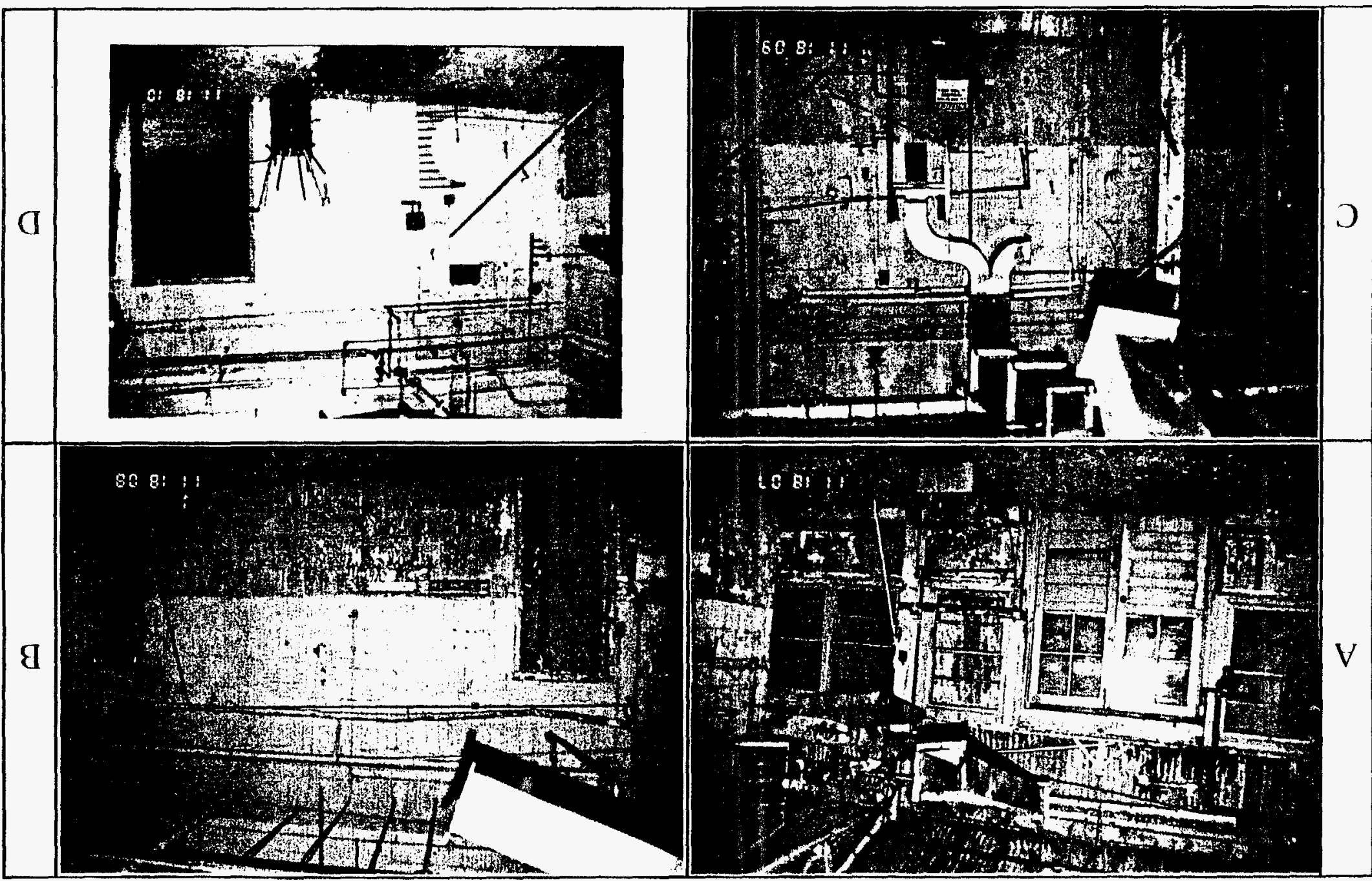

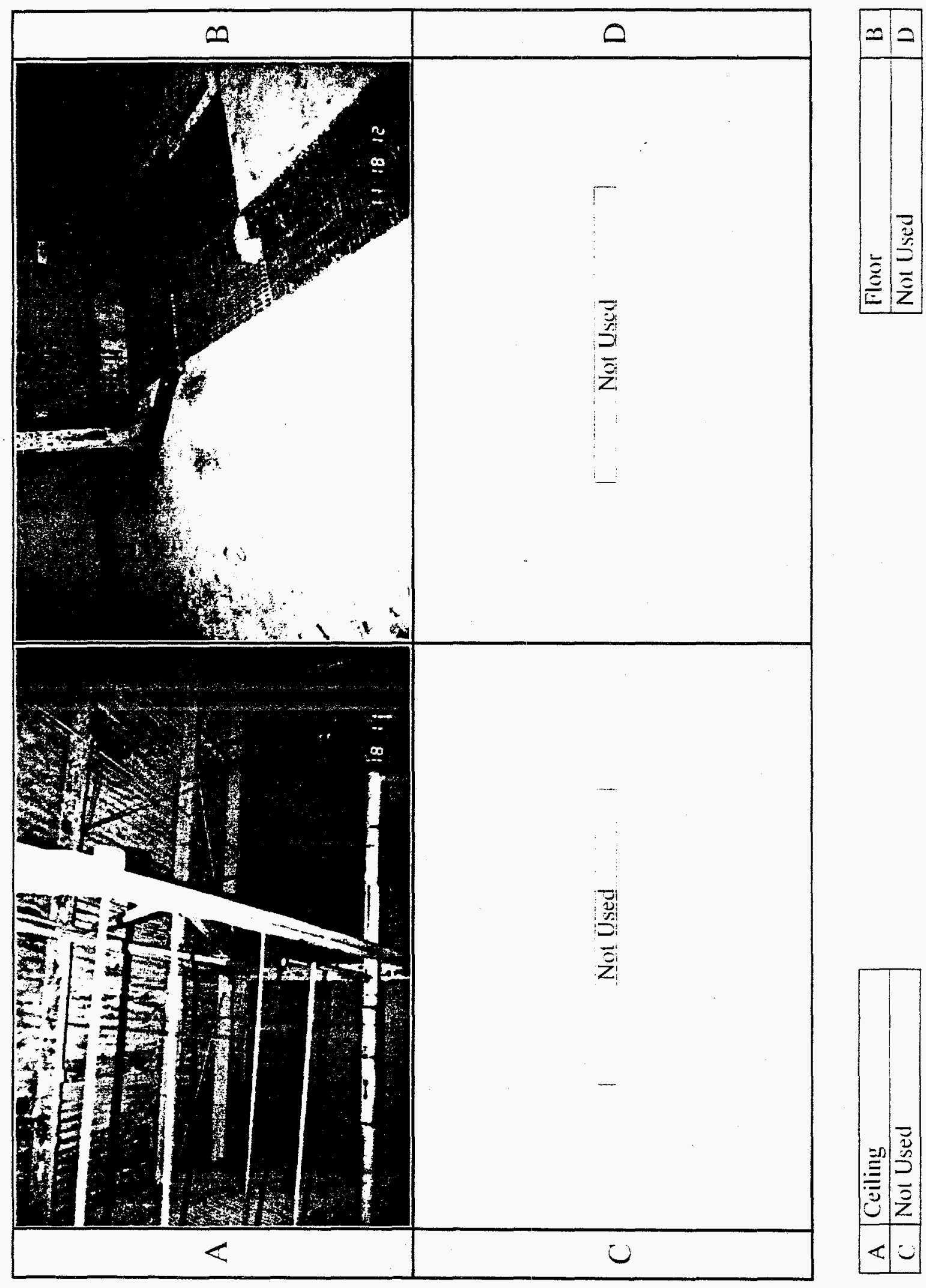

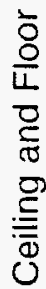

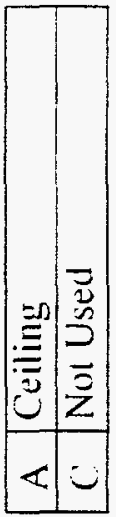



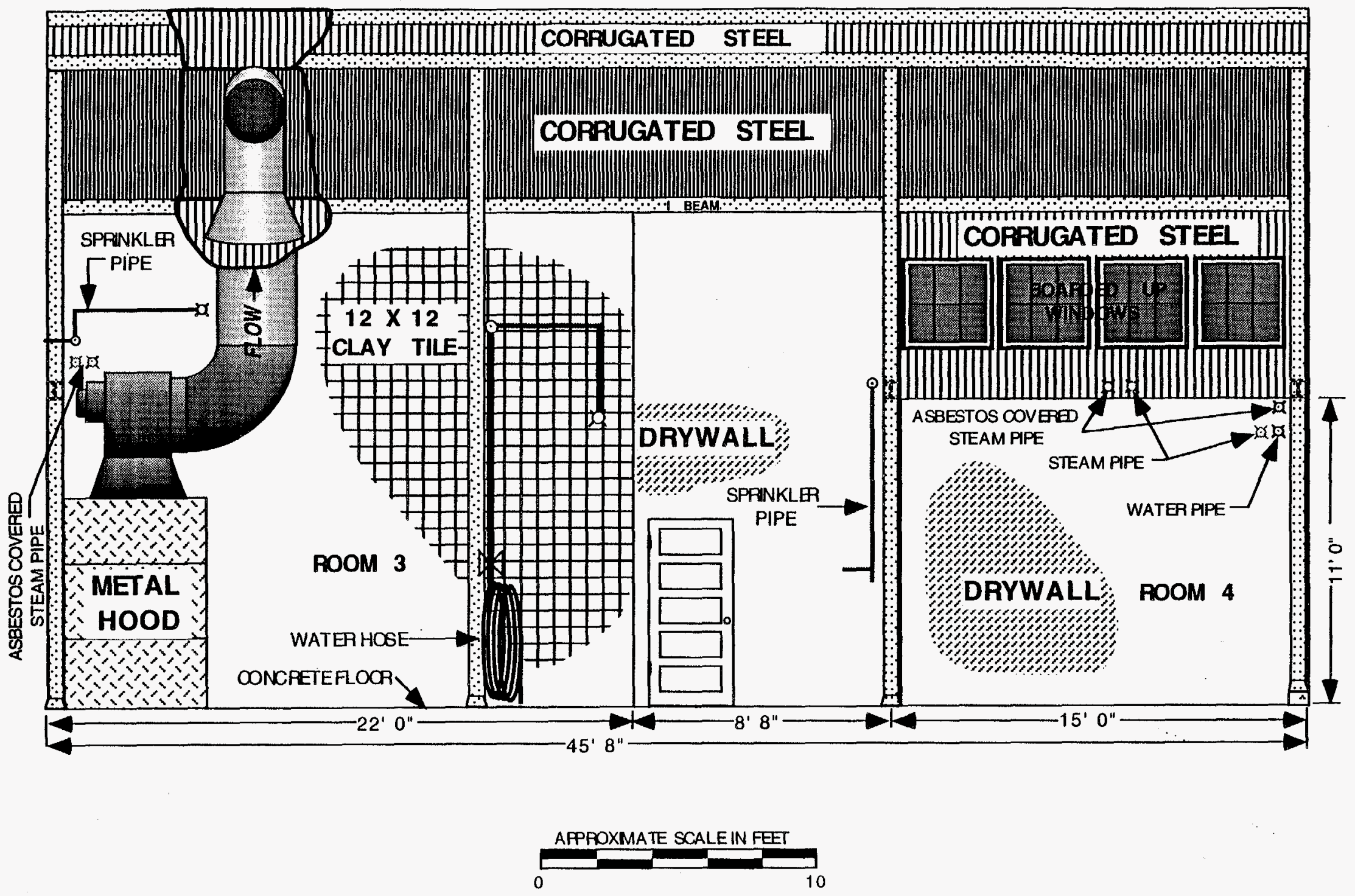

FIGURE 22 Rooms 3 and 4 - North View 


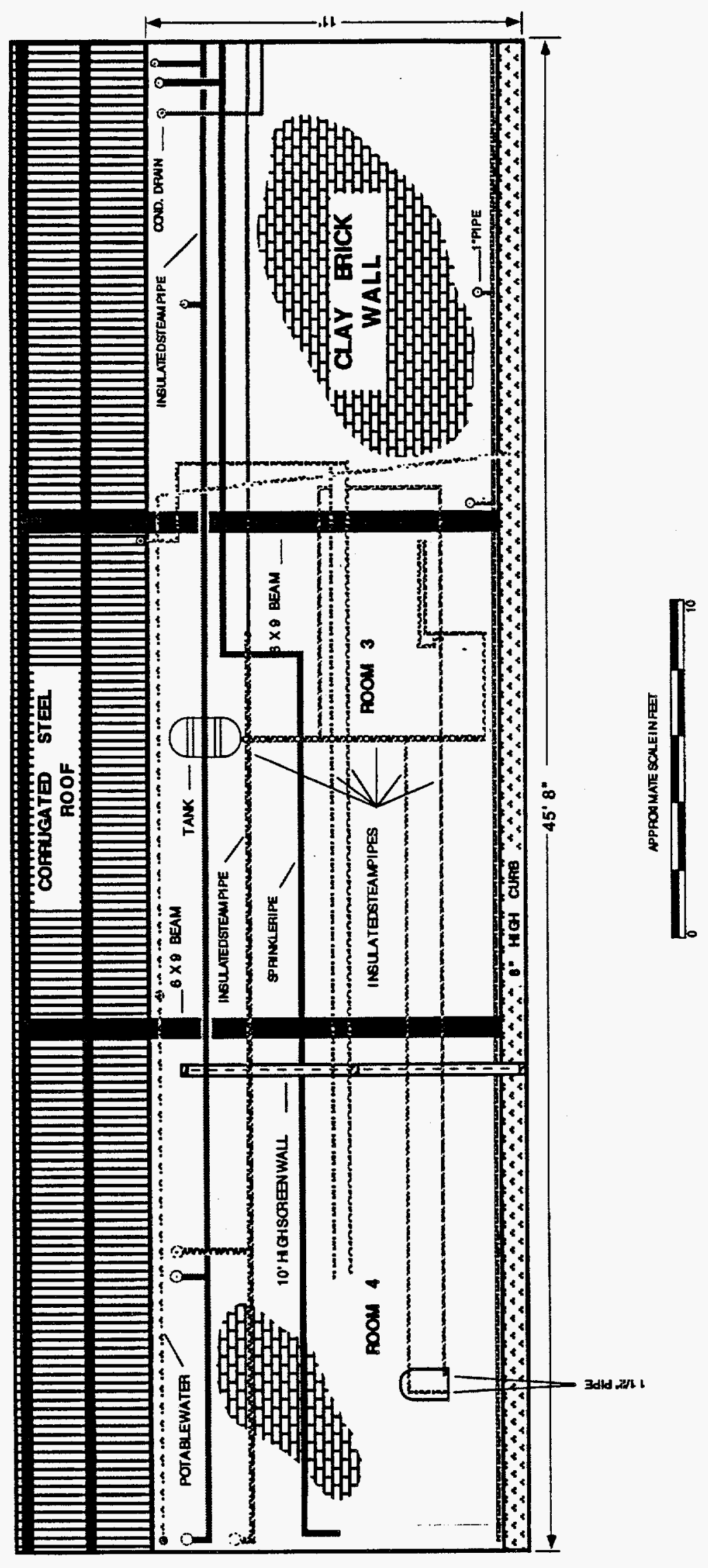

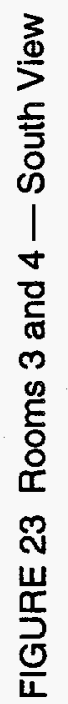




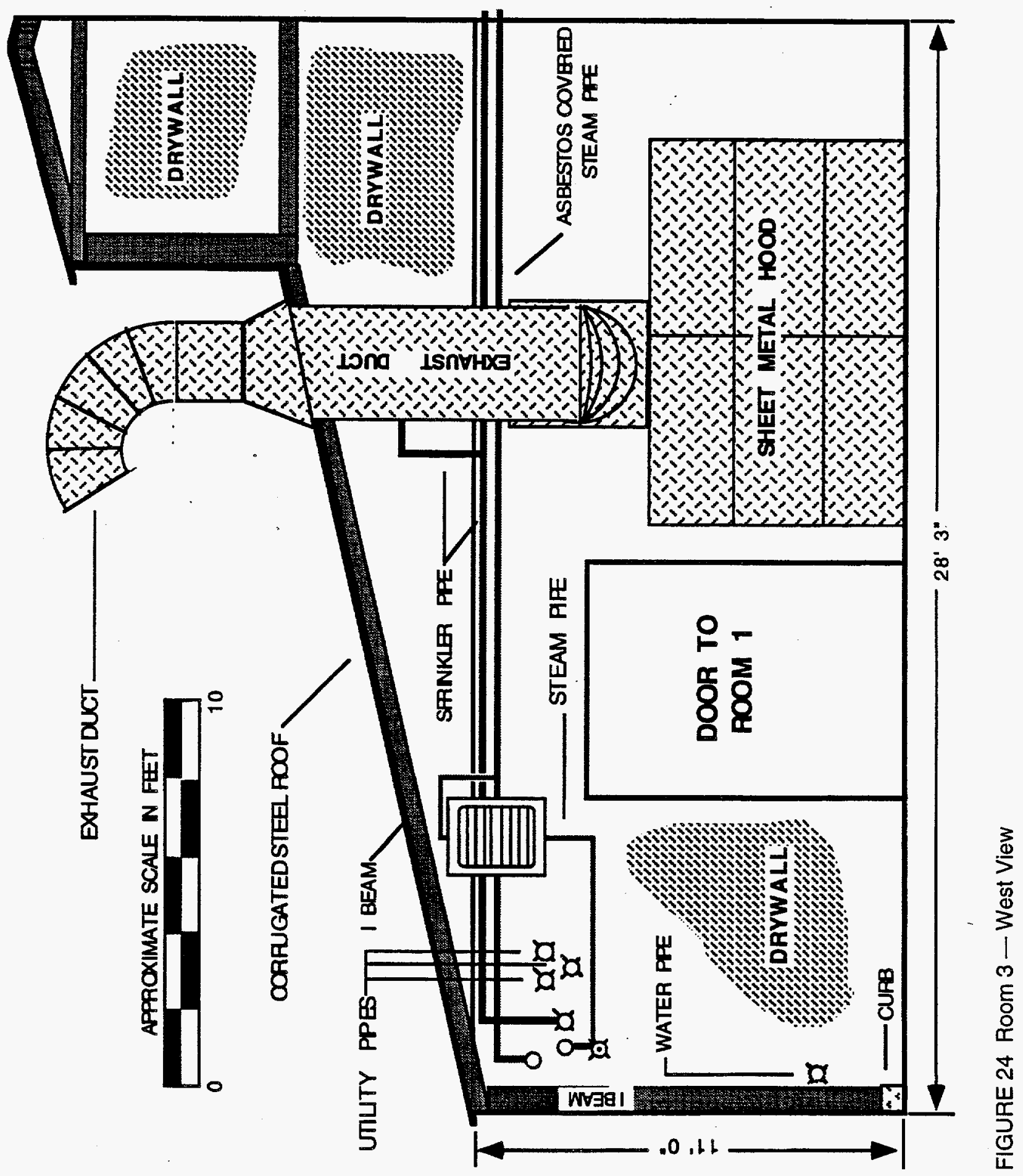




\subsubsection{Equipment}

A metal storage hood approximately $10 \mathrm{ft}$ long, $5 \mathrm{ft}$ deep, and $6 \mathrm{ft}$ high is located on the west wall. A tank is connected to the insulated piping system on the south wall. A space heater was observed above the door that connects this room with room 1 . Utility conduit was noted throughout the room.

One 24-in.-diameter exhaust duct connects the storage hood with the outside roof. This duct extends from the metal hood to the ceiling and to the outside.

\subsubsection{Doors and Windows}

Three doorways lead to rooms 1, 4, and 8. Additional doors connect room 3 to rooms 2, 5 , and the outside. No windows are located in this room.

\subsubsection{Ceiling and Floor}

The ceiling is constructed of corrugated metal sheeting supported by a steel frame. Horizontal steel I-beam girders connect to steel I-beams that cross the center of the ceiling in a north-south direction. The floor is constructed of concrete.

Photographs of the walls and ceiling in room 3 are provided in Figures 25 and 26.

\subsection{Room 4}

\subsubsection{Walls}

The exterior walls are constructed of brick and corrugated metal sheeting. The interior walls are constructed of drywall, clay tile brick, wood, and 12-in. by 12 -in. clay tile. A 10-ft-high wire fence separates rooms 3 and 4 (Figure 27).

\subsubsection{Finish Materials}

The walls of room 4 are painted green and white. 

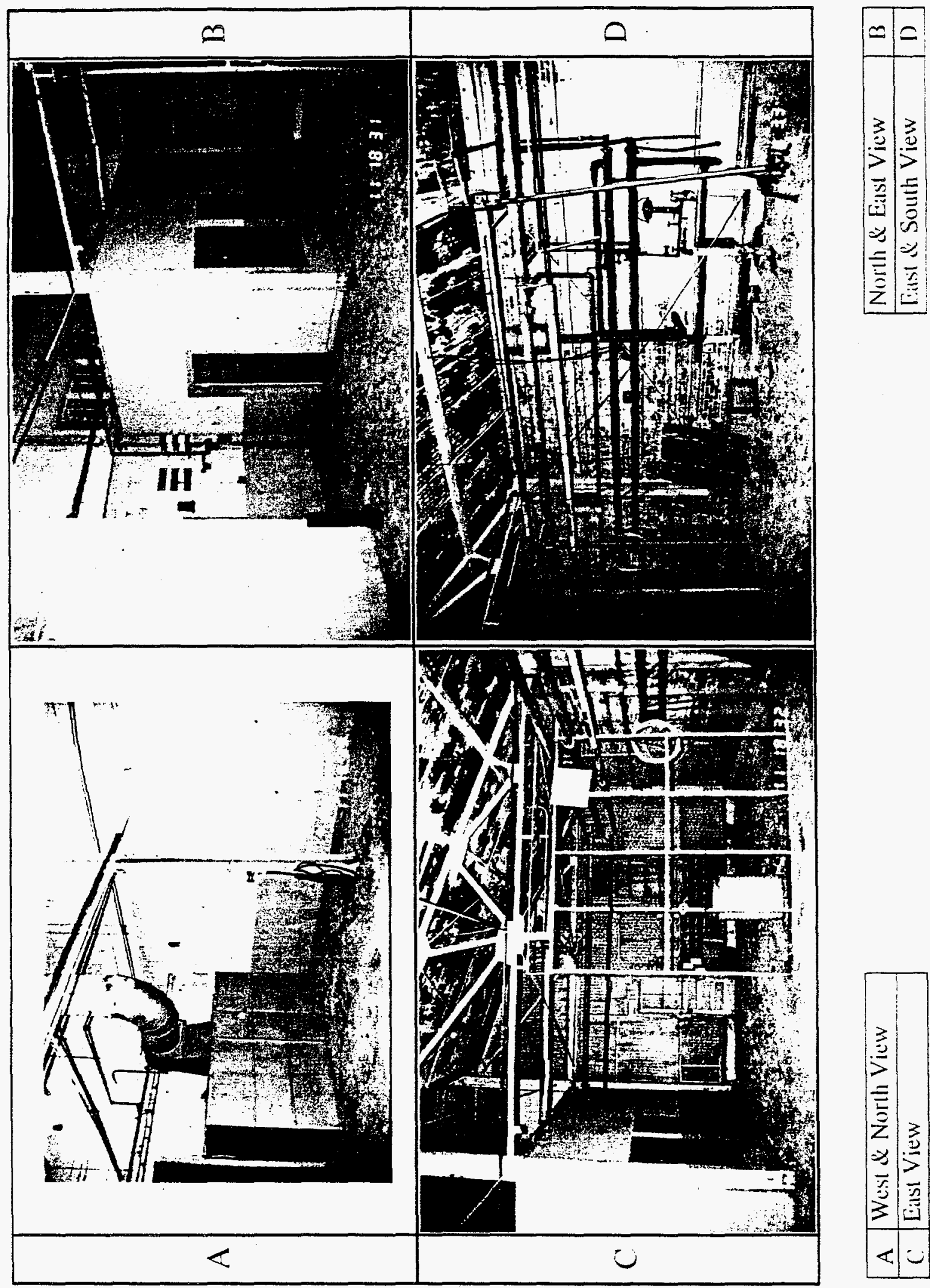

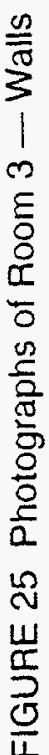



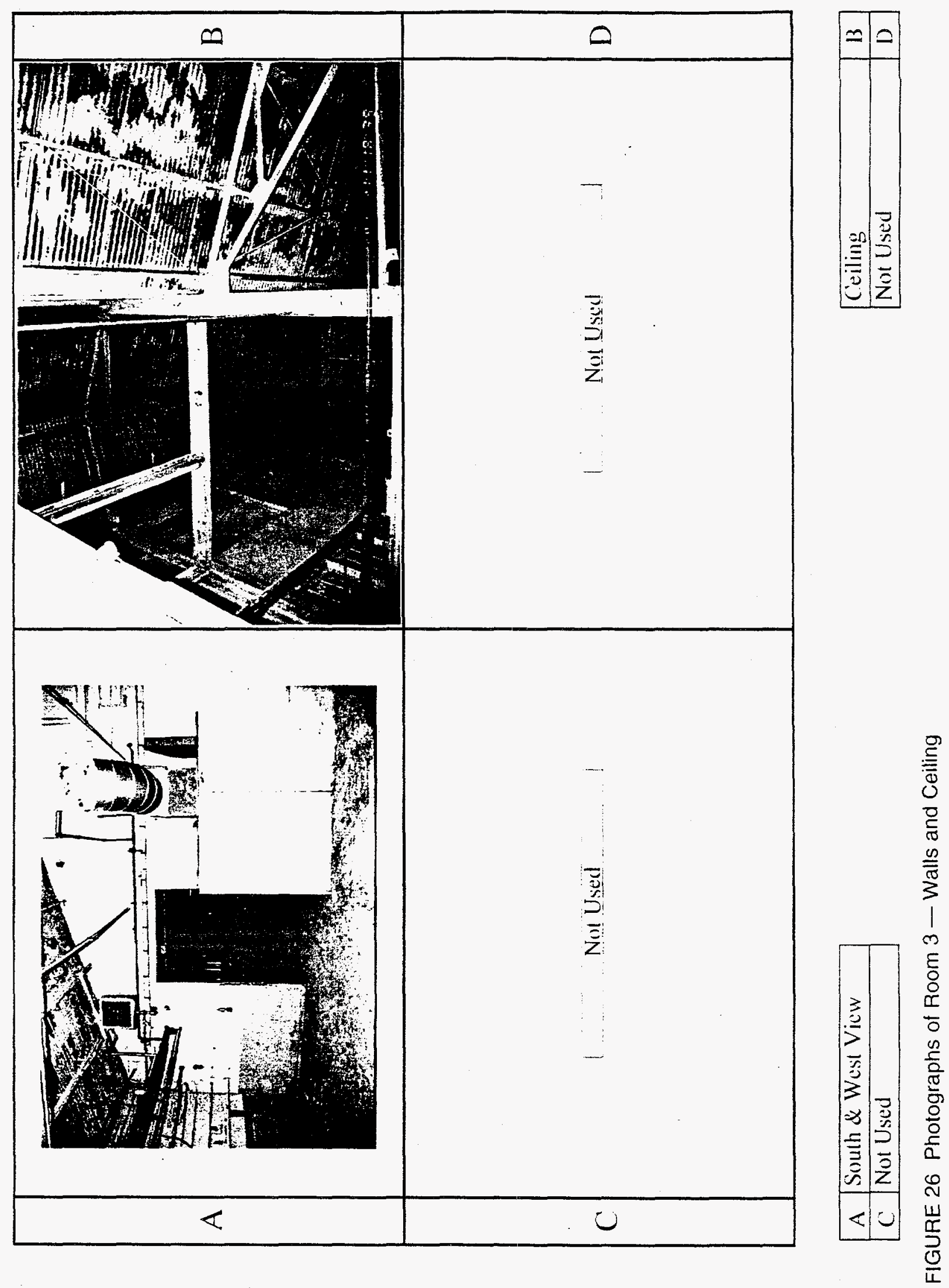

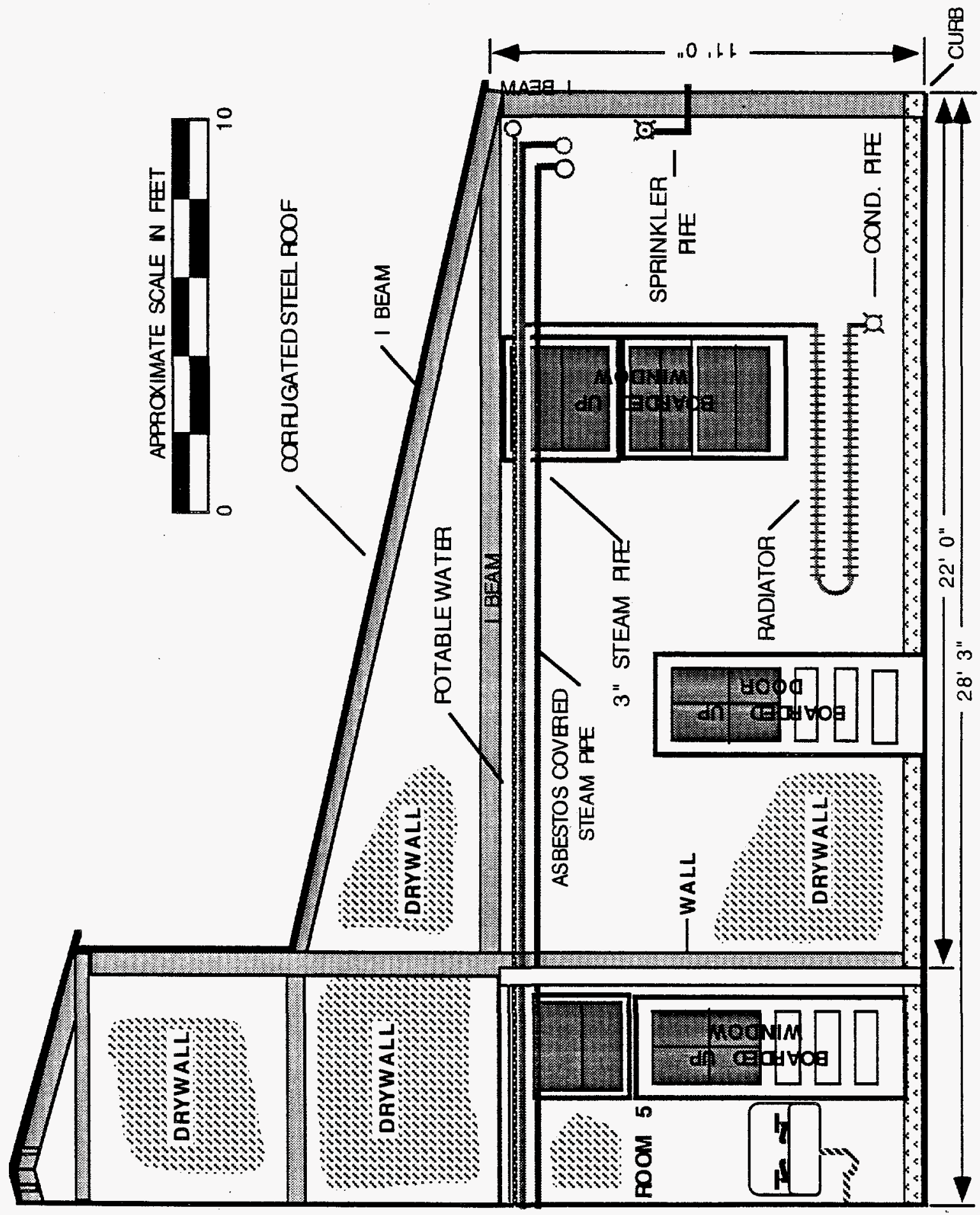

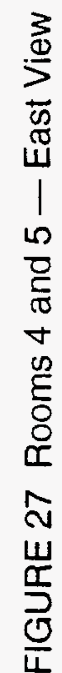




\subsubsection{Piping}

Room 4 contains various piping systems from previous operations in the building. The south wall contains a large number of pipes.

\subsubsection{Equipment}

A radiator connected to the steam pipes is located on the east wall of room 4 . Utility conduit runs throughout the room.

\subsubsection{Doors and Windows}

The windows of the room are boarded over with plywood. One doorway leads to room 3 .

\subsubsection{Ceiling and Floor}

The ceiling is constructed of corrugated metal sheeting supported by a steel frame. Horizontal steel I-beam girders connect to steel I-beams that cross the center of the ceiling in a north-south direction. The floor is constructed of concrete.

Figures 28 and 29 provide photographs of the walls, ceiling, and floor in room 4.

\subsection{Room 5}

\subsubsection{Walls}

The walls of room 5 are constructed of drywall, wood, and corrugated metal sheeting (Figures 30 through 33). The east and south walls are $10 \mathrm{ft}$ high. The other walls match the height of the building. An interior shower stall is constructed of transite. The frames of the commode and shower stall are constructed of wood.

\subsubsection{Finish Materials}

The walls are painted green and white. 


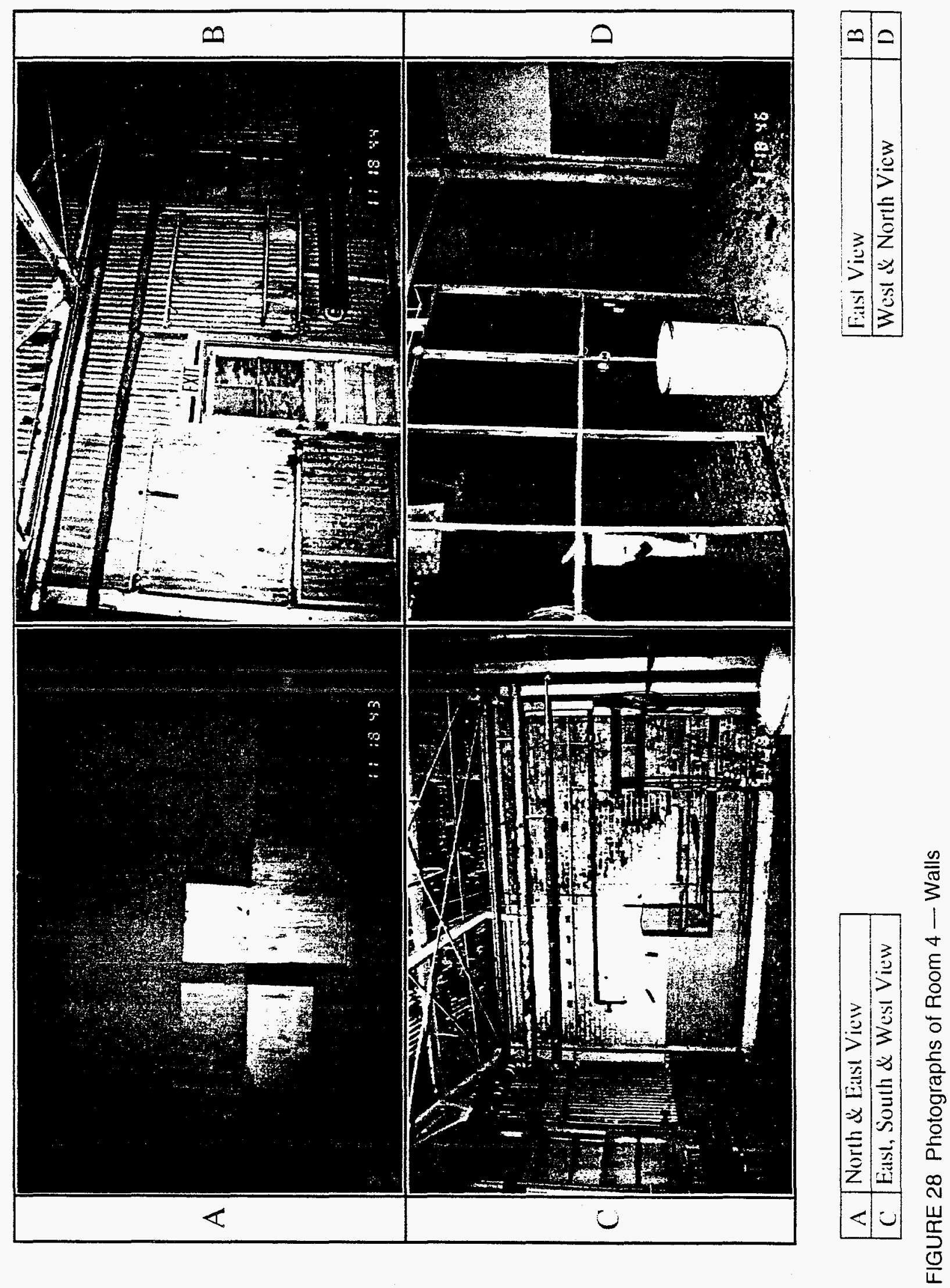




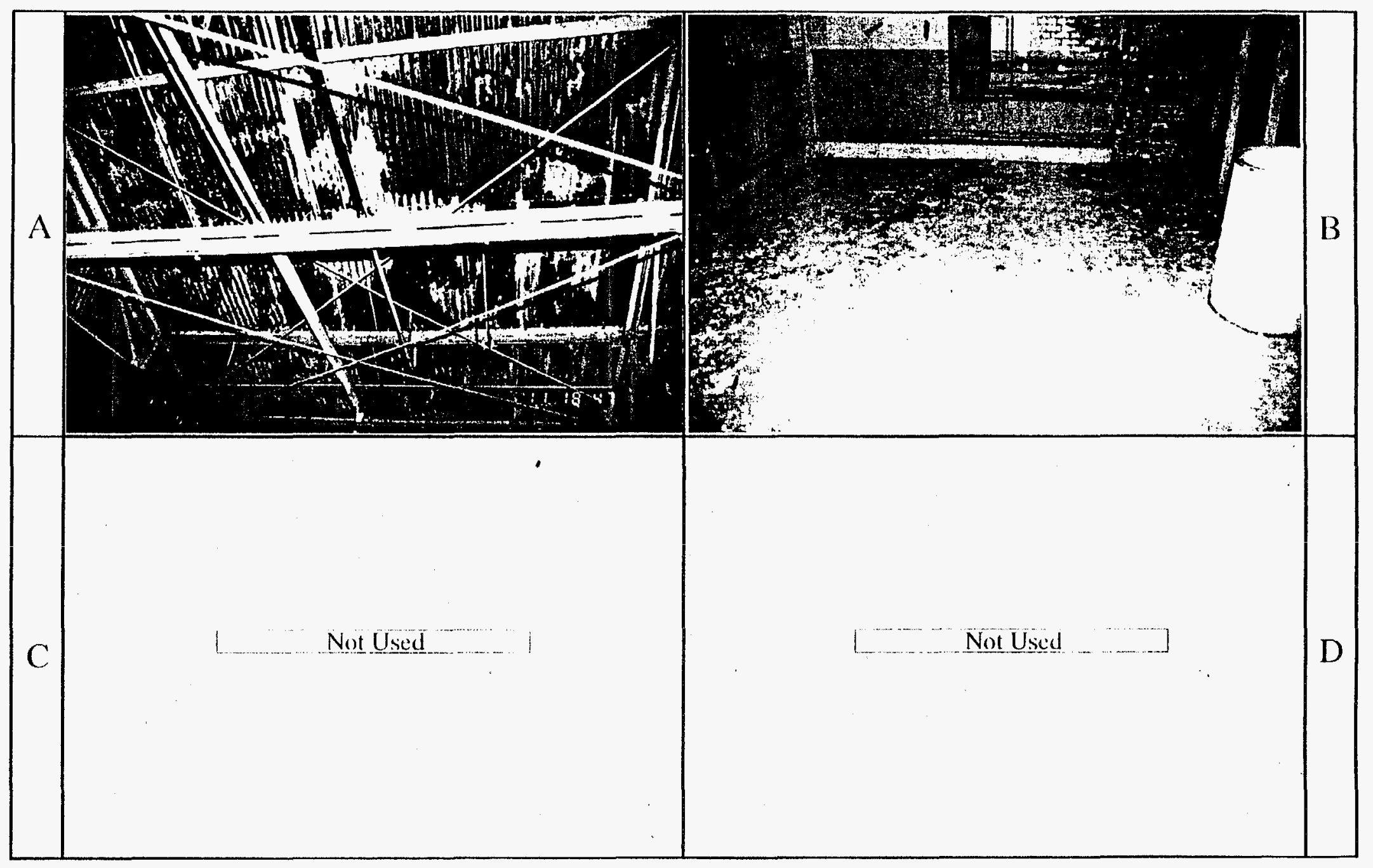

\begin{tabular}{|l|l|}
\hline A & Ceiling \\
\hline$C$ & Not Used \\
\hline
\end{tabular}

\begin{tabular}{|l|l|}
\hline Floor & B \\
\hline Not Used & D \\
\hline
\end{tabular}

FIGURE 29 Photographs of Room 4 - Ceiling and Floor 


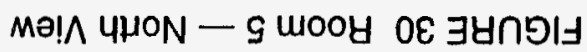

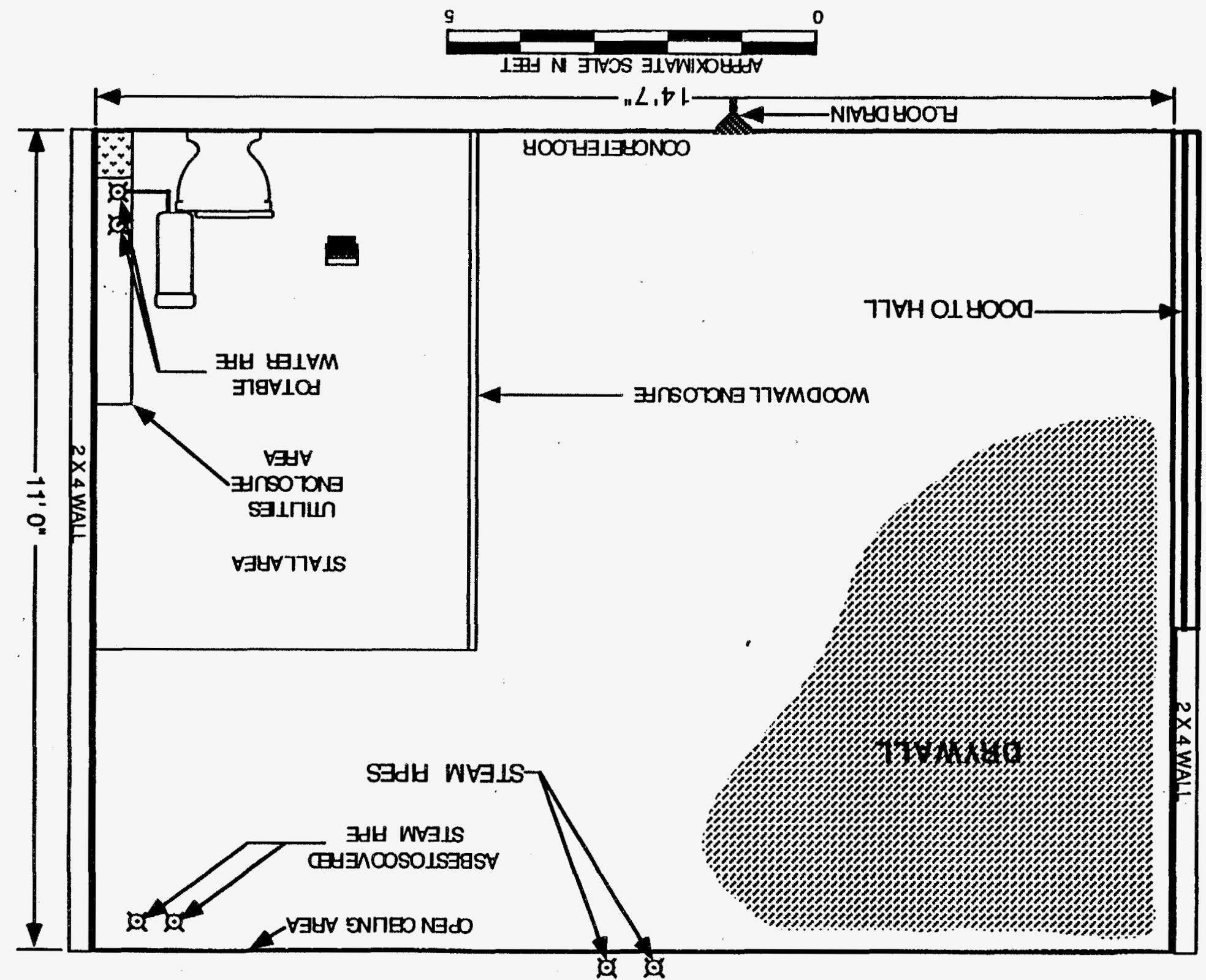


OPEN CEILING AREA

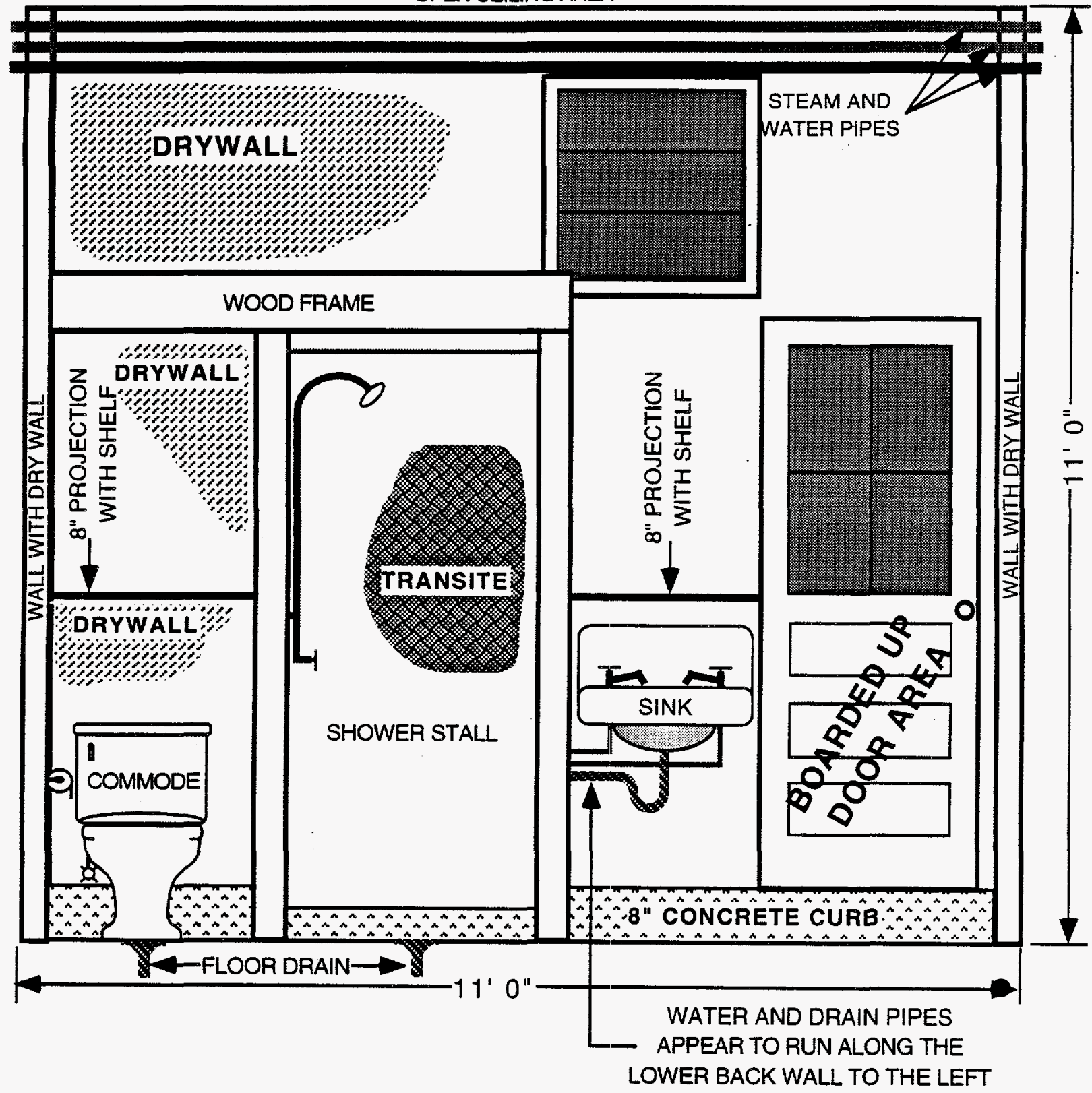

APPROXIMATE SCALE IN FEET

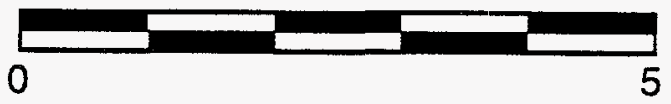

FIGURE 31 Room 5 - East View 


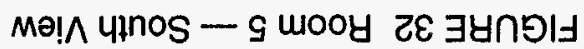

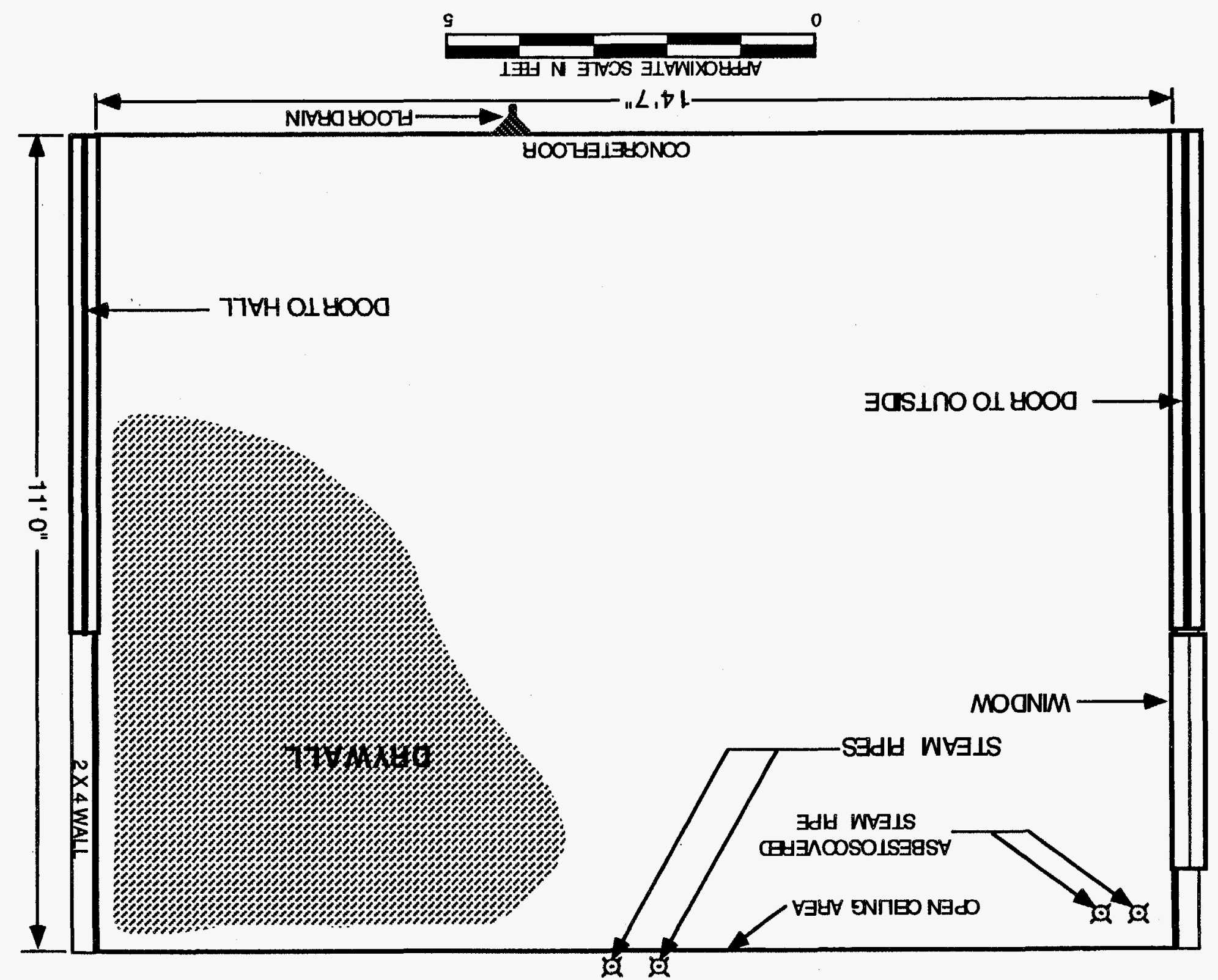


OFEN CEILING AFEA

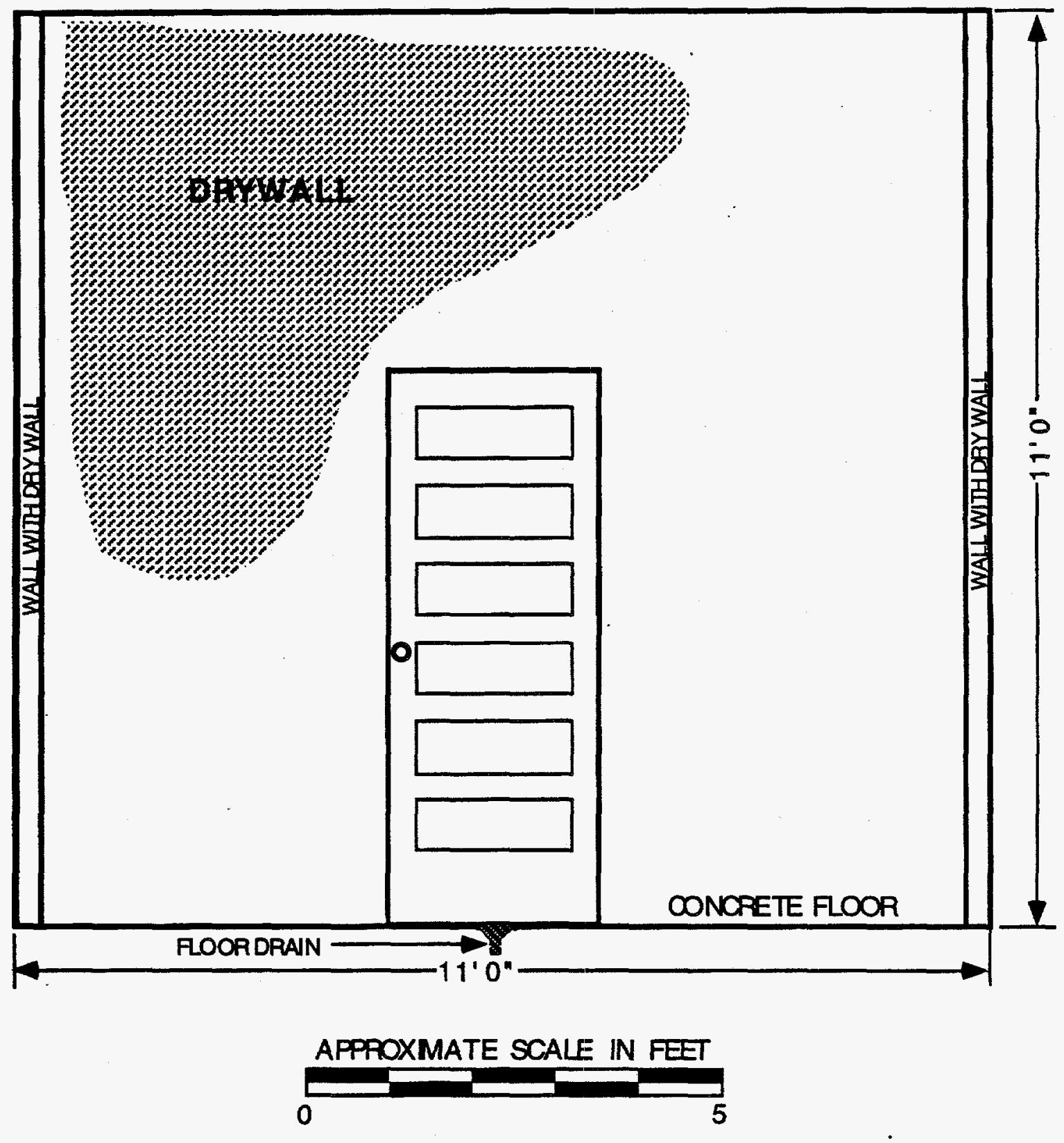

FIGURE 33 Room 5 - West View 


\subsubsection{Piping}

Room 5 contains various piping systems, located mainly along the east wall of the room. Steam pipes covered by suspect asbestos-containing insulation are located on the north, south, and east walls. Water and drain pipes are connected to the shower, sink, and commode. Piping connects with a heater on the north wall.

\subsubsection{Equipment}

Room 5 contains two heaters, two lights, a shower stall, a commode, and a sink. An electrical box was observed on the north wall. Electrical conduit runs throughout the room.

\subsubsection{Doors and Windows}

One door is located on each of the east and west walls and one on the stall. There are three windows on the east wall and four on the north.

\subsubsection{Ceiling and Floor}

Room 5 has a painted corrugated sheet metal ceiling. The floor is constructed of concrete. One floor drain is located near the center of the room. Another is associated with the shower.

Figures 34 and 35 provide photographs of the walls, ceiling, and floor of room 5.

\subsection{Room 6}

\subsubsection{Walls}

The walls of room 6, constructed of drywall and wood, are $11 \mathrm{ft}$ high (Figures 36 through 38).

\subsubsection{Finish Materials}

The walls are painted green and white. 


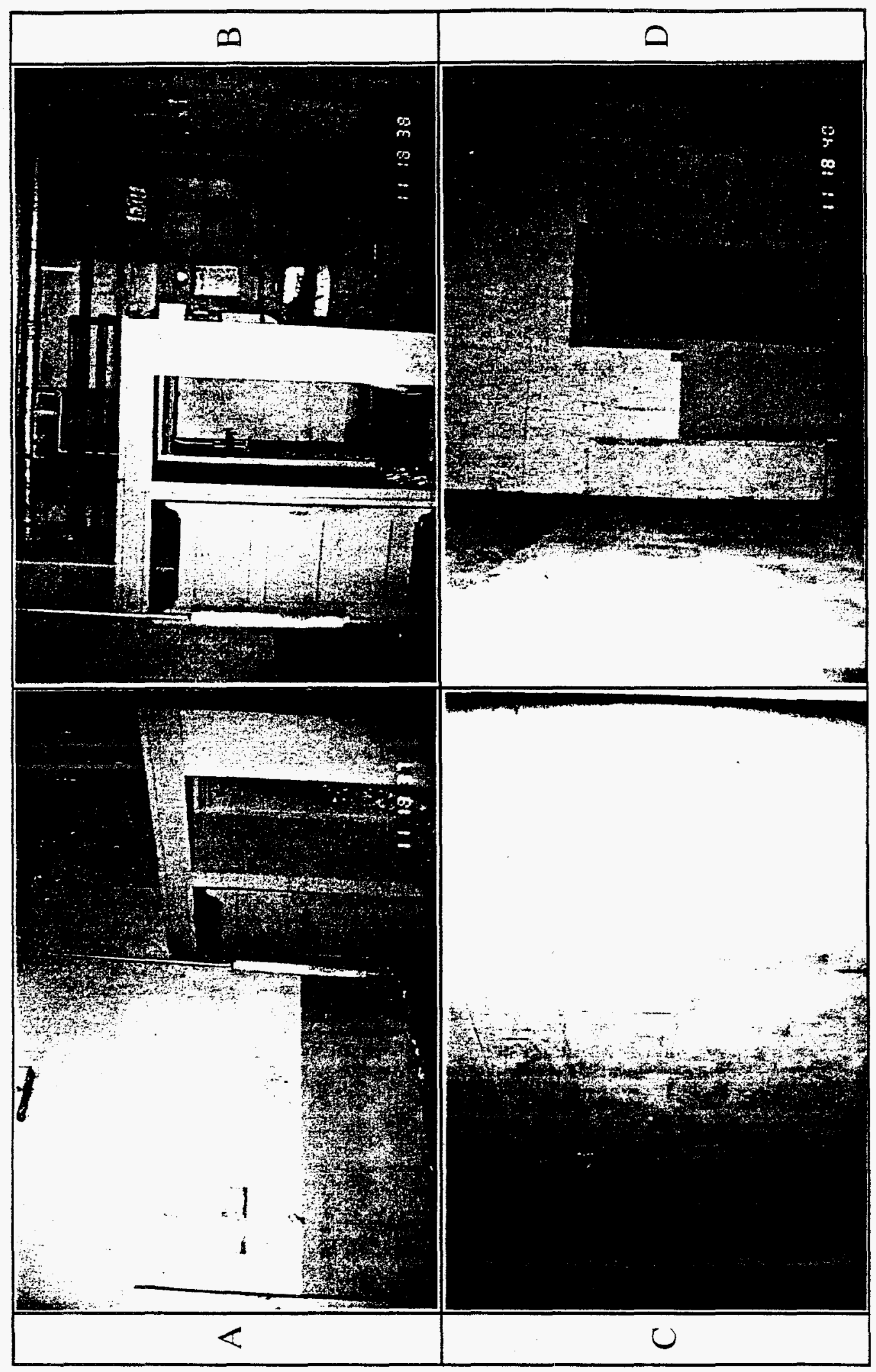

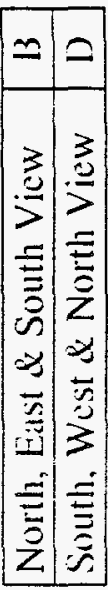

$\stackrel{\frac{\infty}{\pi}}{3}$

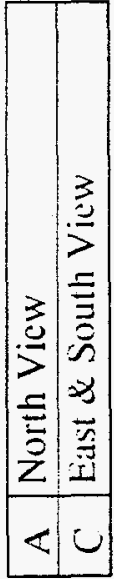

เก

응

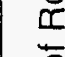

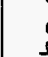

$\frac{1}{2}$

总离

产苛

응

문

ले

$\stackrel{4}{\cong}$ 

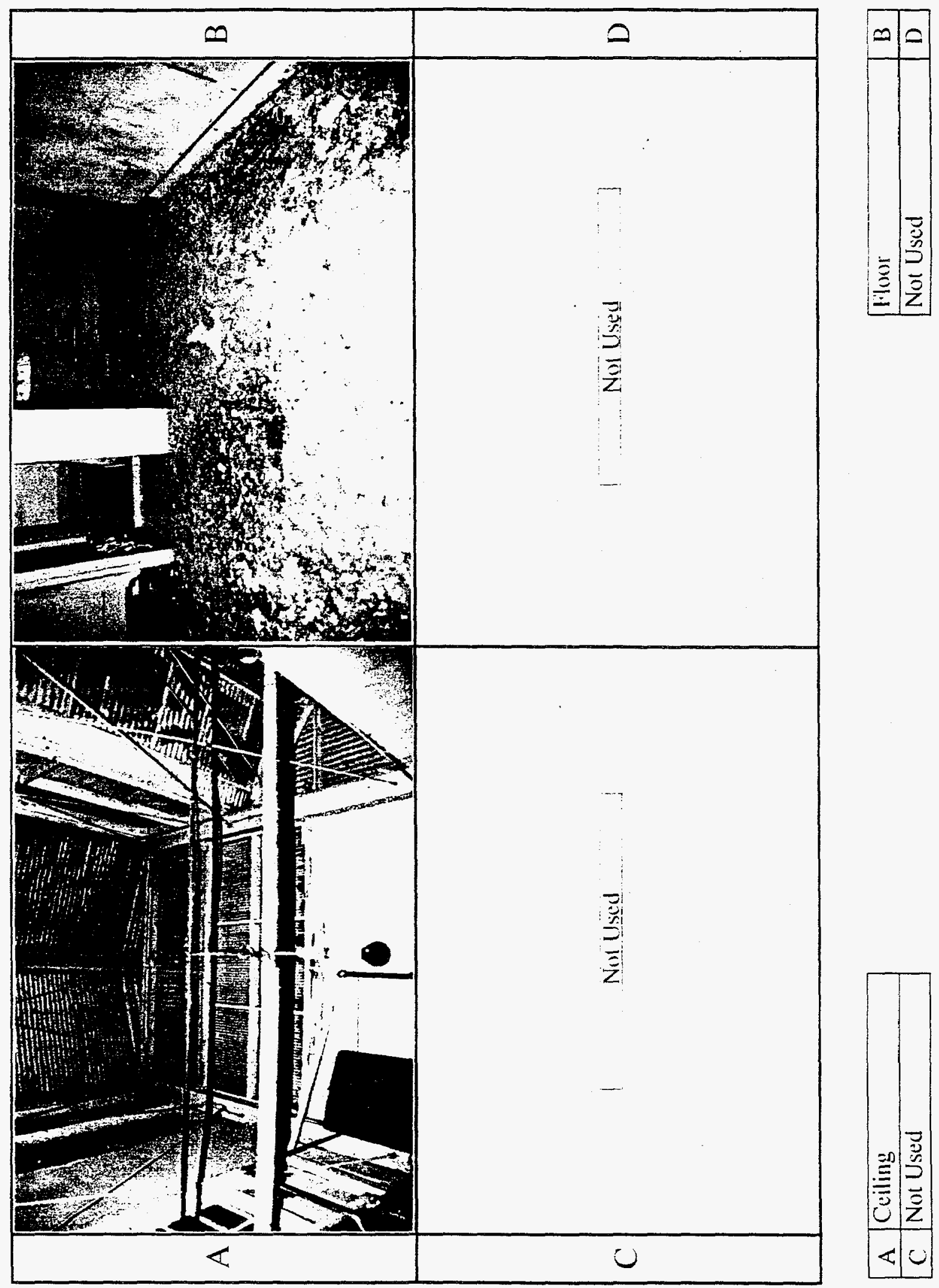

흠

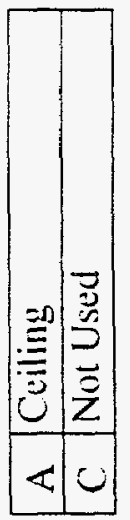

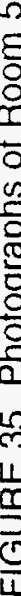




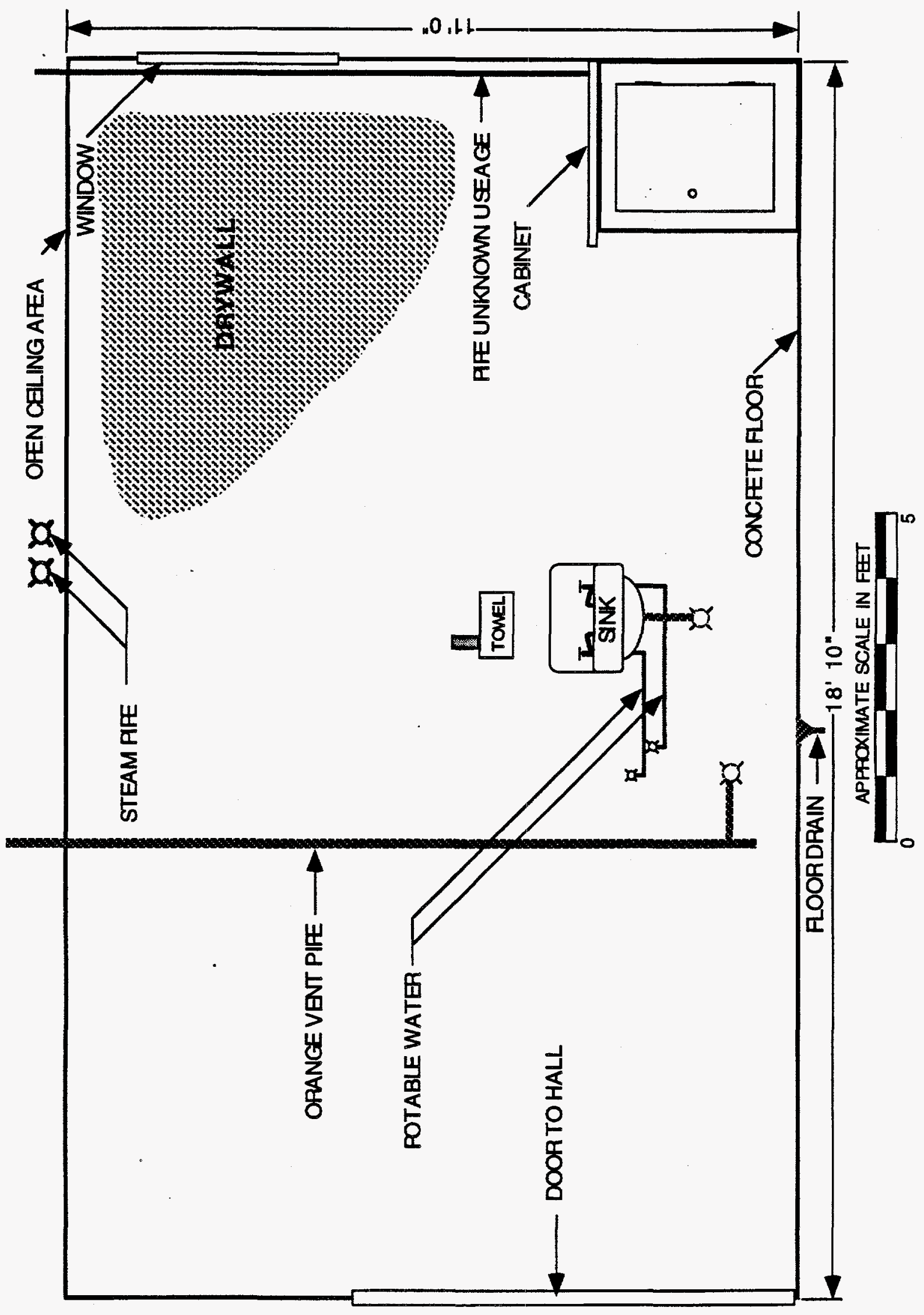

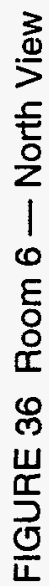




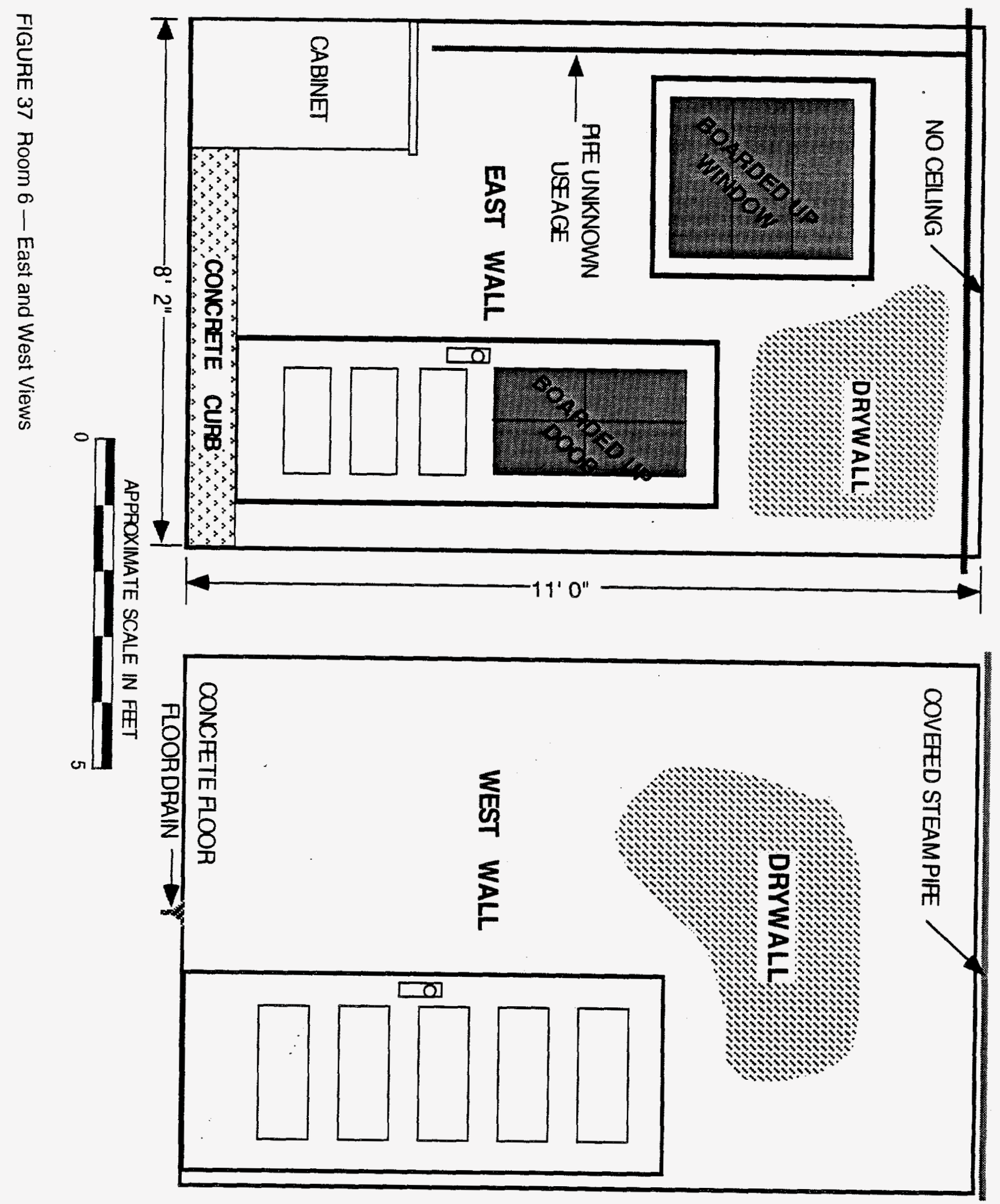




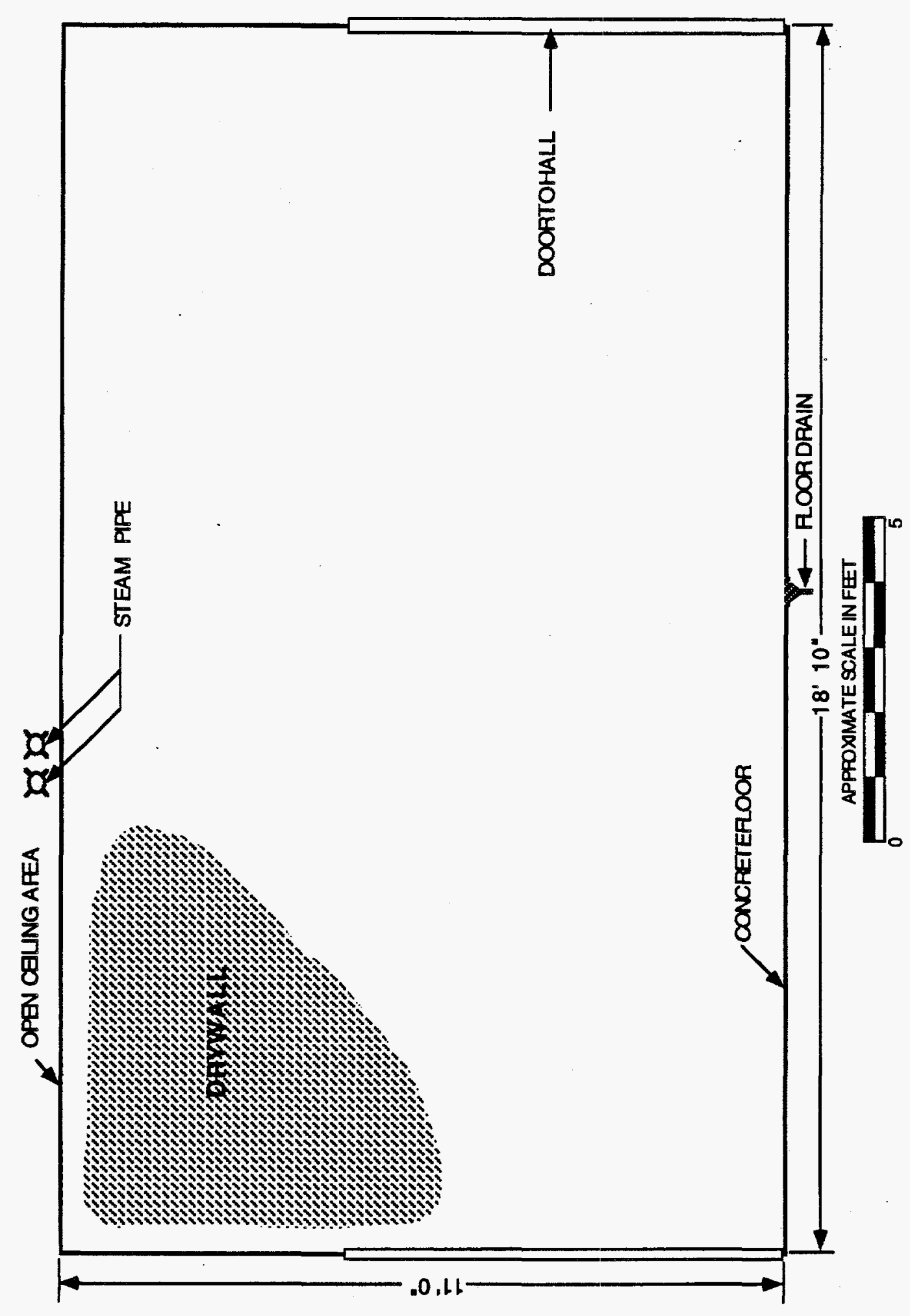

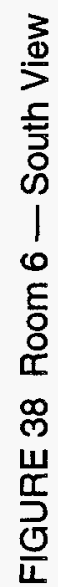




\subsubsection{Piping}

Room 6 consists of various piping systems, located mainly near or at the top of the walls.

\subsubsection{Equipment}

Room 6 contains a cabinet, sink, light, heater, and electrical conduit.

\subsubsection{Doors and Windows}

One door is on the east wall and another one is on the west wall. There is one window on the east wall and four windows on the south wall.

\subsubsection{Ceiling and Floor}

The ceiling in room 6 is made of corrugated metal painted white. The floor is constructed of concrete. One floor drain is located near the center of the room.

Figures 39 and 40 provide photographs of the walls, ceiling, and floor of room 6.

\subsection{Room 7}

\subsubsection{Walls}

The walls are constructed of plywood and drywall. The frames for the two shower stalls and commode are made of plywood and drywall. The interior walls of the room are $11 \mathrm{ft}$ in height (Figures 41 through 44).

\subsubsection{Finish Materials}

The walls are painted green and white. 

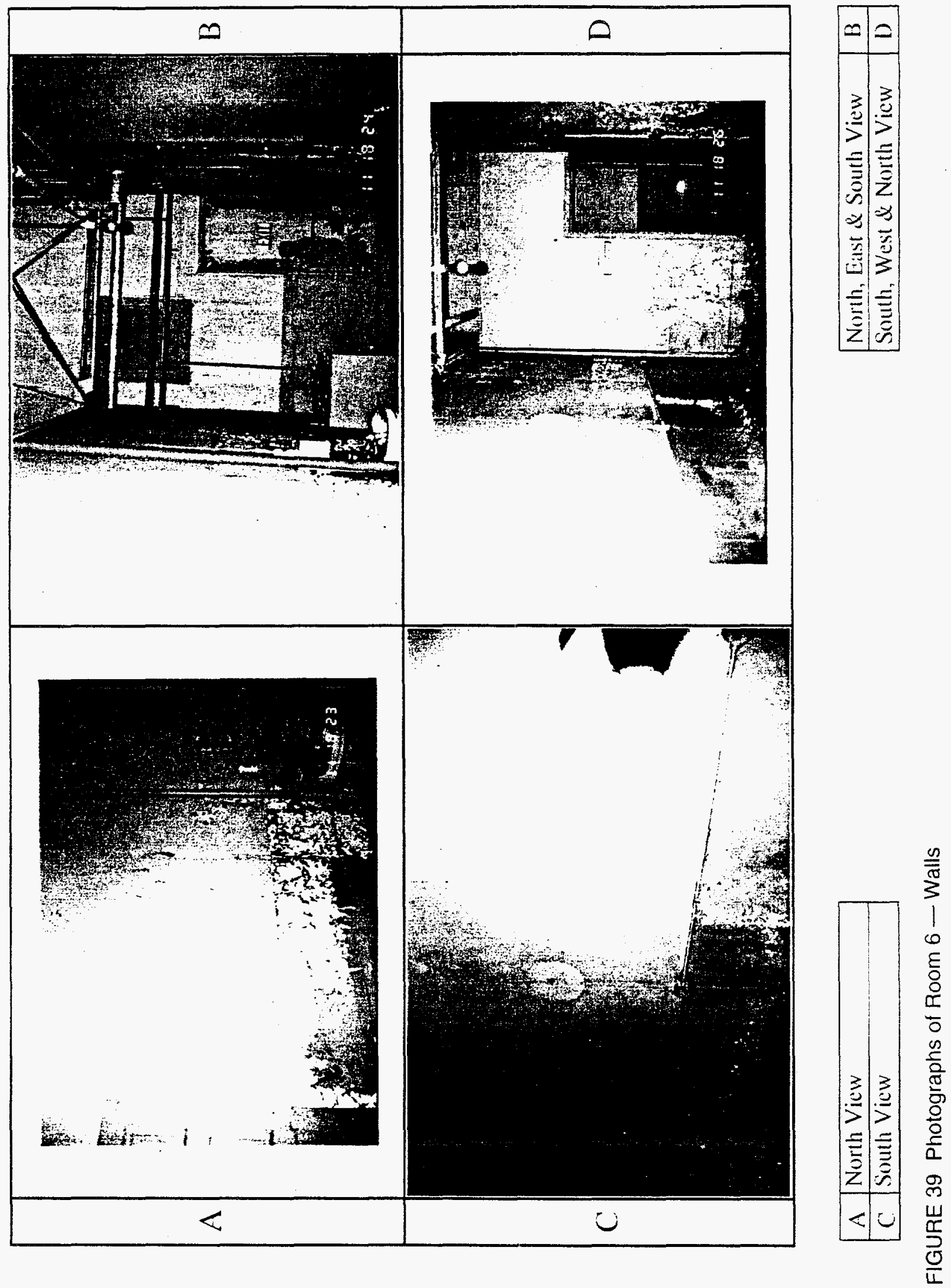

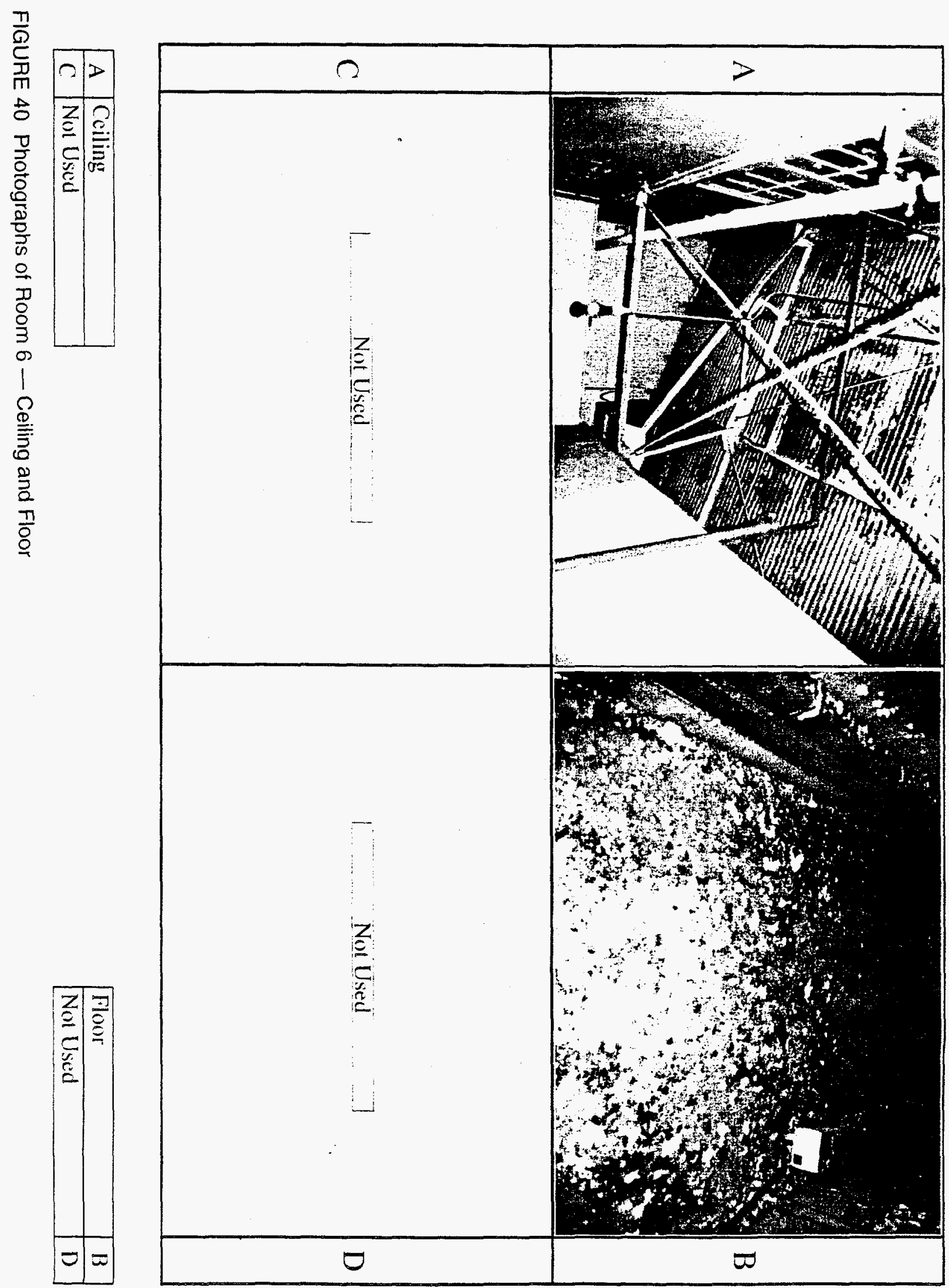


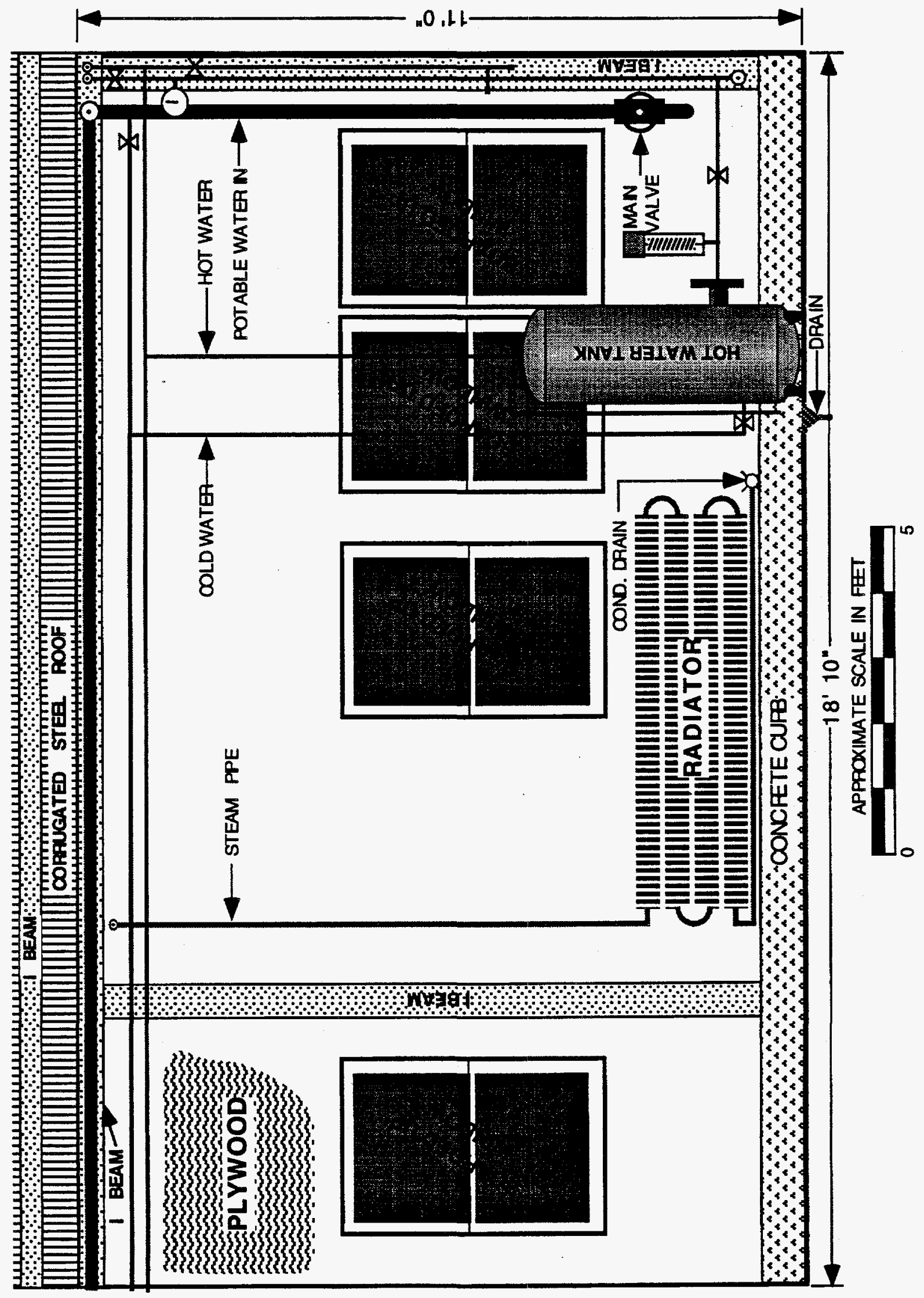

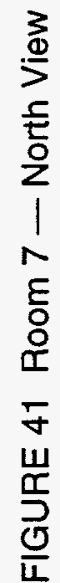




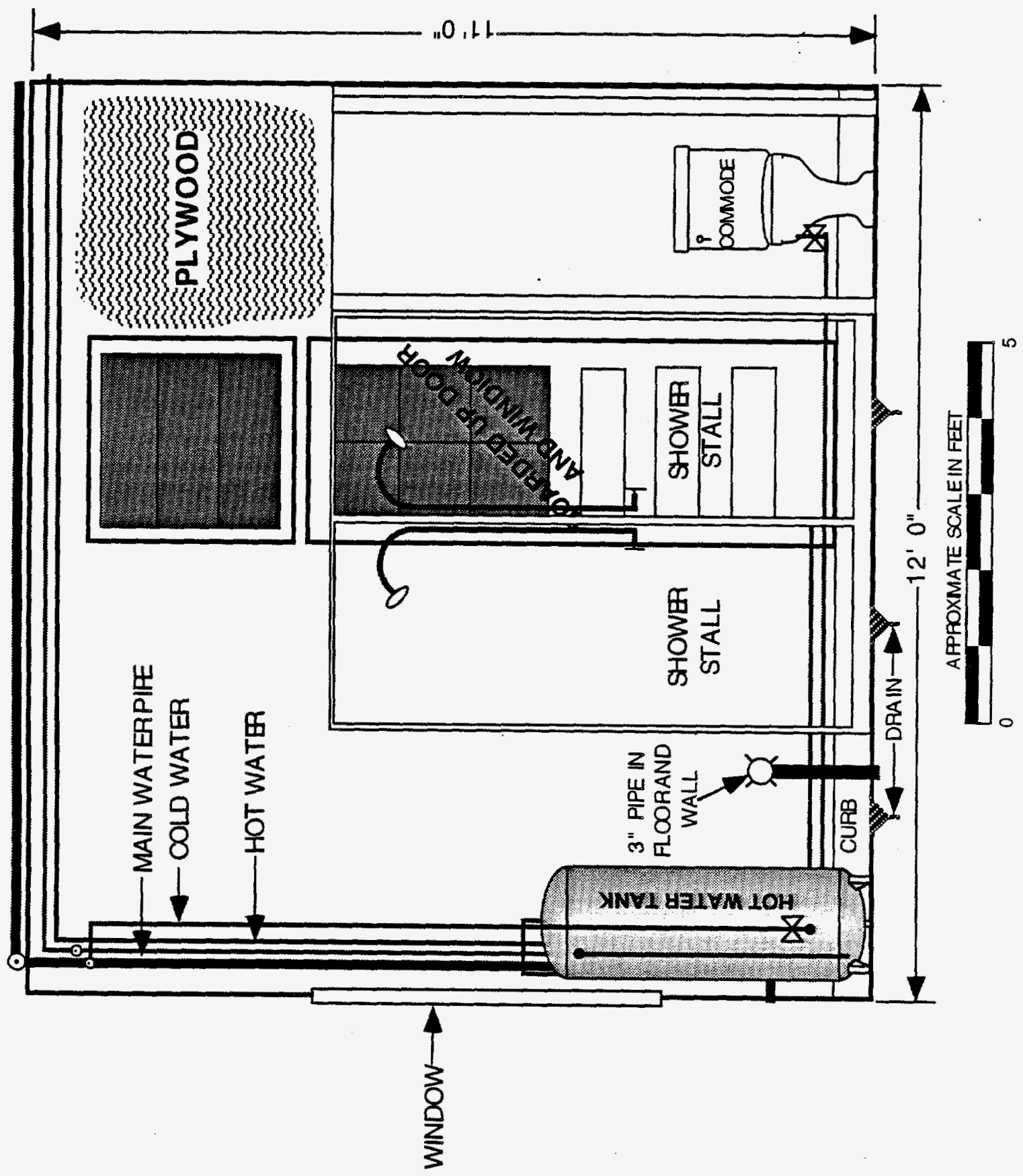

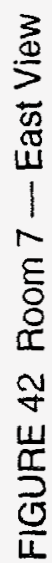




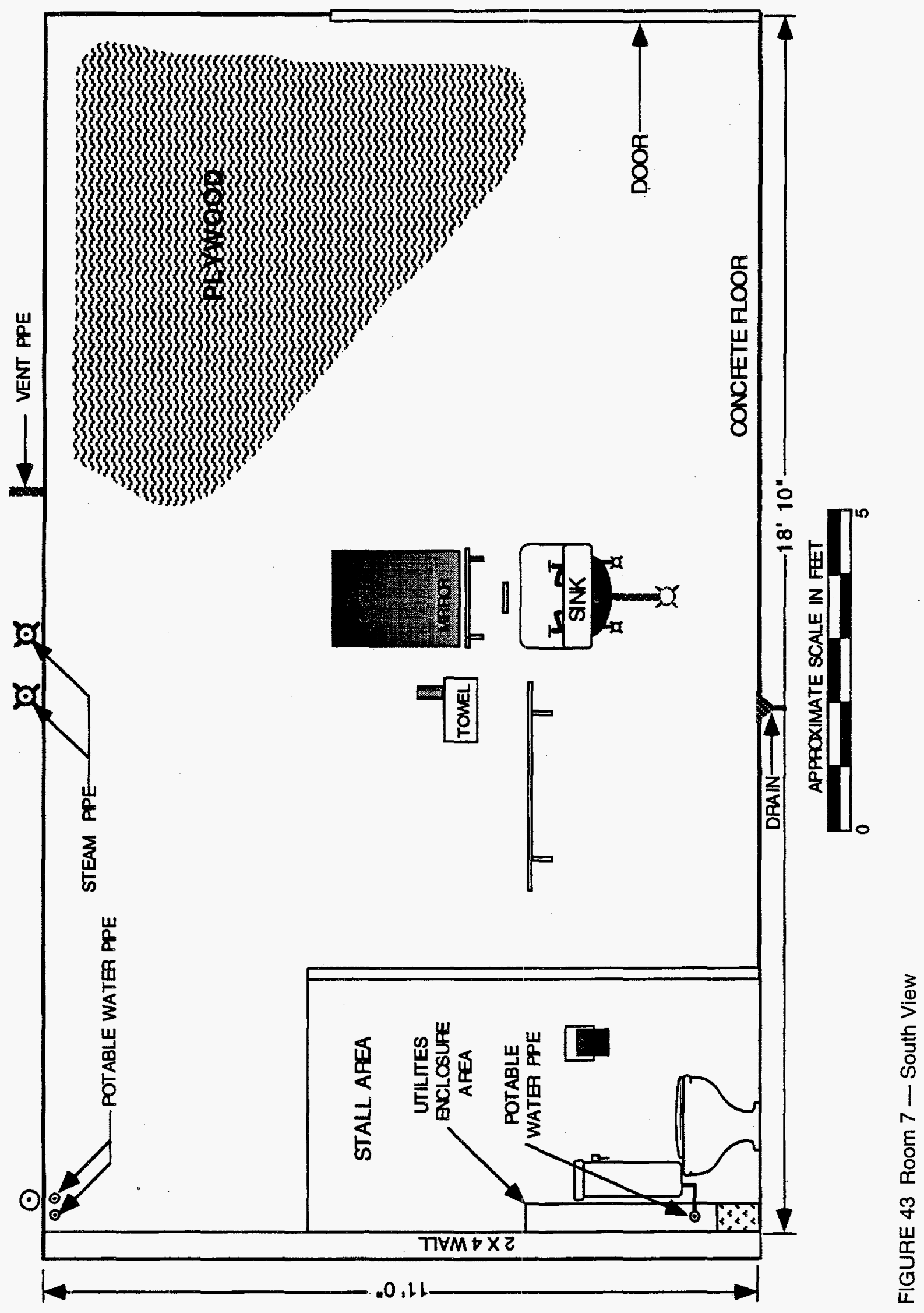




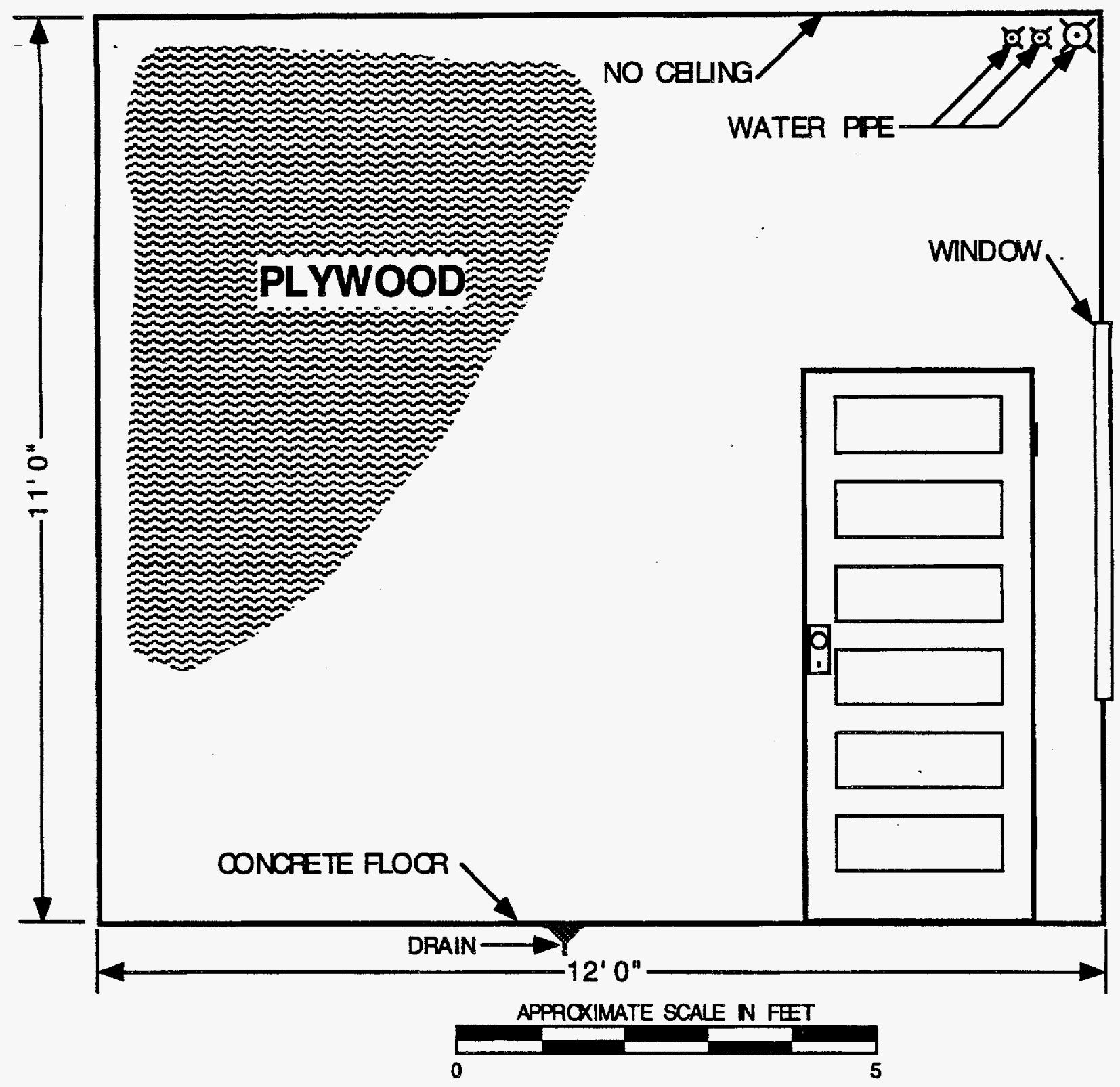

FIGURE 44 Room 7 - West View 


\subsubsection{Piping}

Room 7 contains various piping systems, located mainly on or near the north and east walls of the room. Drain pipes are connected to the sink and the commode.

\subsubsection{Equipment}

Room 7 , formerly used as a locker room, contains two showers, a commode, and a sink area. A hot water tank and radiator are located against the north wall. The room contains the steam main line, a light, and a thermostat. Electrical conduit runs throughout the room.

\subsubsection{Doors and Windows}

One door is on each of the east and west walls. There are four windows on the north wall and one on the east.

\subsubsection{Ceiling and Floor}

The ceiling is white-painted corrugated sheet metal. The floor is constructed of concrete. Floor drains are located in each of the two shower stalls. Two other floor drains are located in the floor of the room.

Figures 45 and 46 provide photographs of the walls, ceiling, and floor of room 7.

\subsection{Room 8}

\subsubsection{Walls}

The walls are constructed of clay tile, drywall, and corrugated metal sheeting.

\subsubsection{Finish Materials}

The walls are painted green and white. 


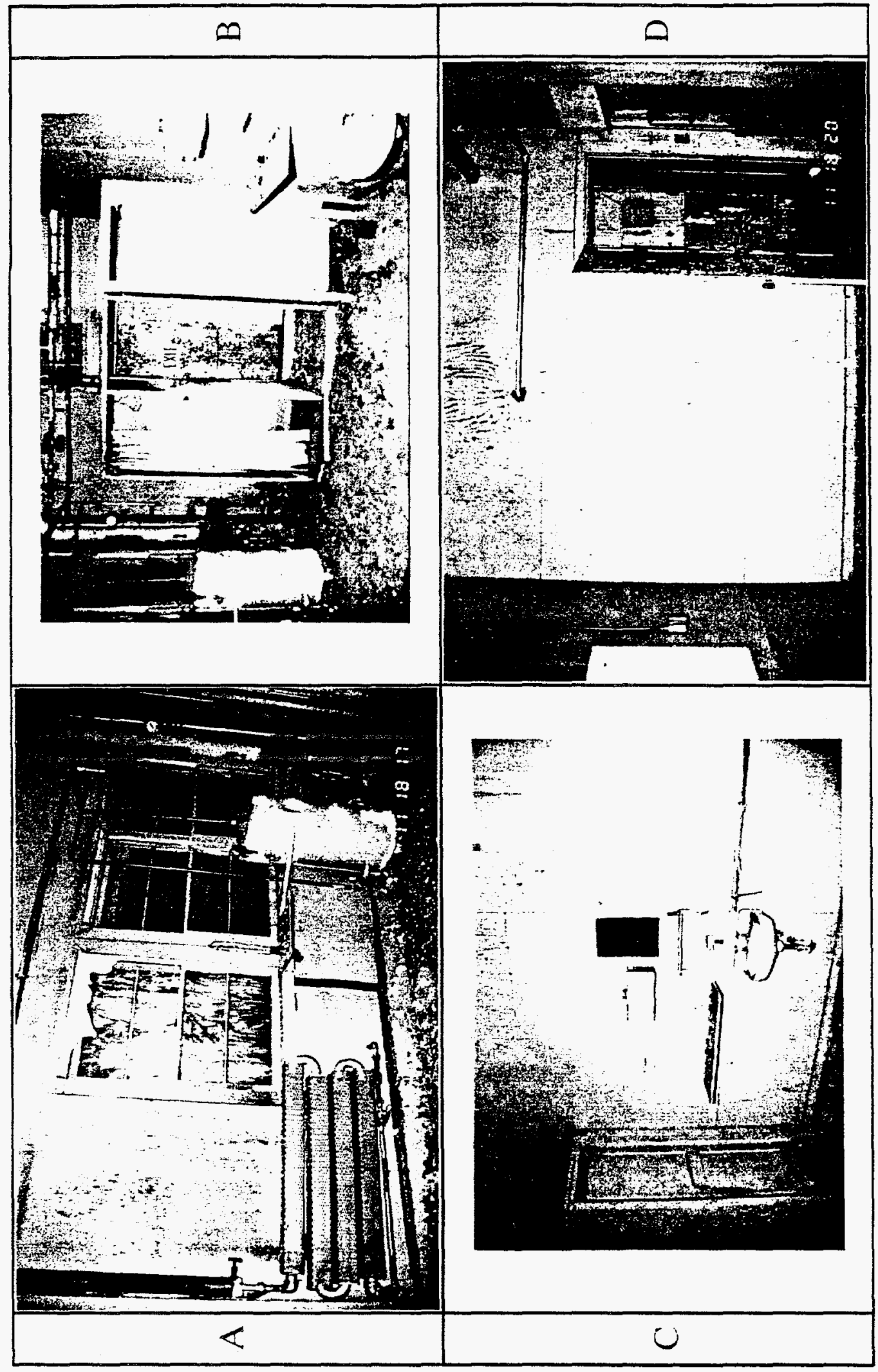



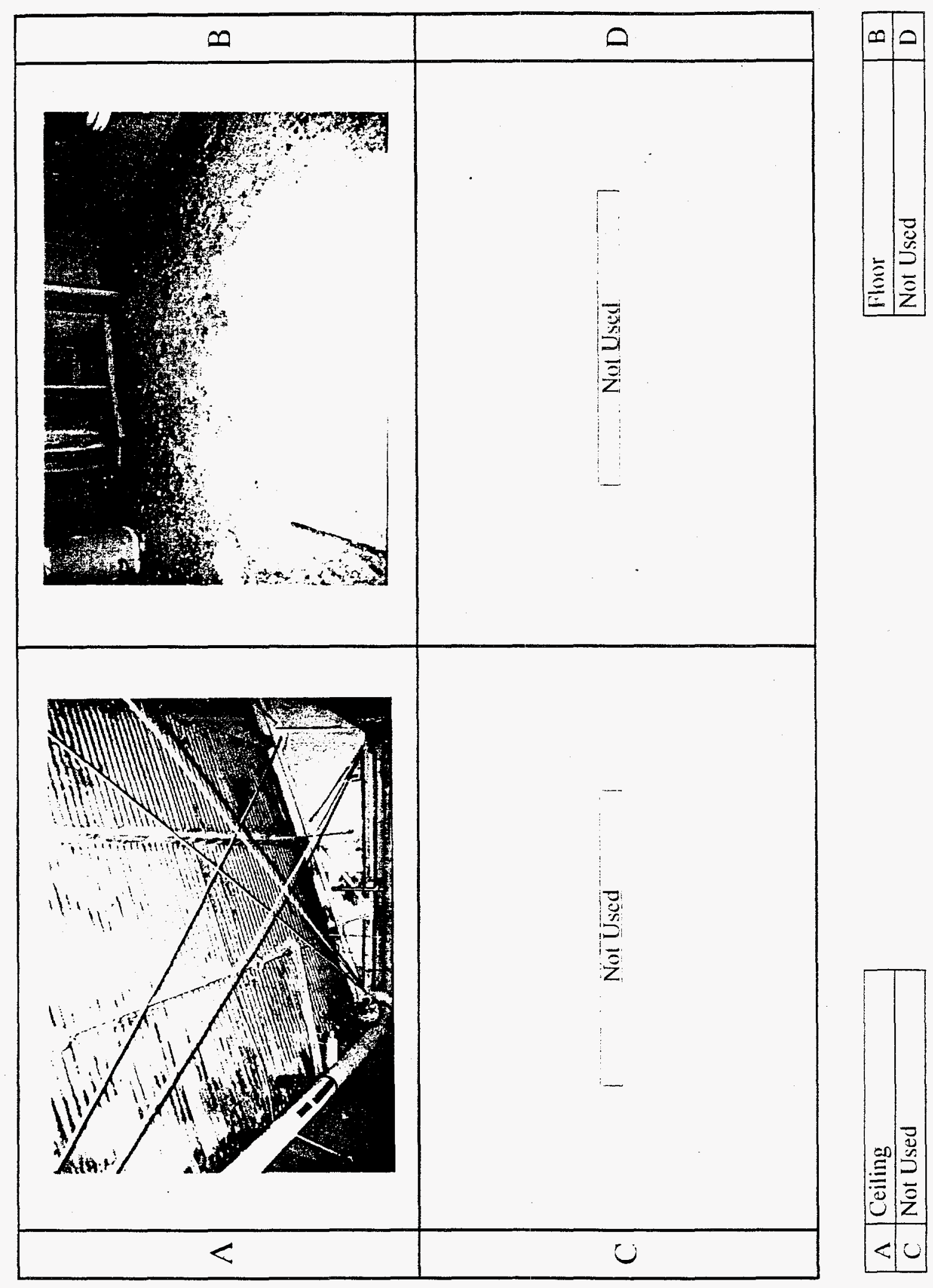

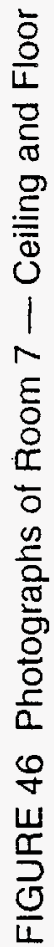




\subsubsection{Piping}

Remnants of pipes were observed in the room.

\subsubsection{Equipment}

Room 8 contains one space heater. Electrical conduit runs throughout the room.

\subsubsection{Doors and Windows}

Room 8 contains five doors and no windows.

\subsubsection{Ceiling and Floor}

The ceiling is constructed of white-painted corrugated sheet metal. The floor is concrete.

Figure 47 provides photographs of the walls, ceiling, and floor of room 8 .

\subsection{Cubicles 1A, 2A, 3A, and 4A}

\subsubsection{Walls}

The four cubicles are constructed of red brick and are not connected to the main building.

\subsubsection{Finish Materials}

The walls are painted white.

\subsubsection{Piping}

None. 

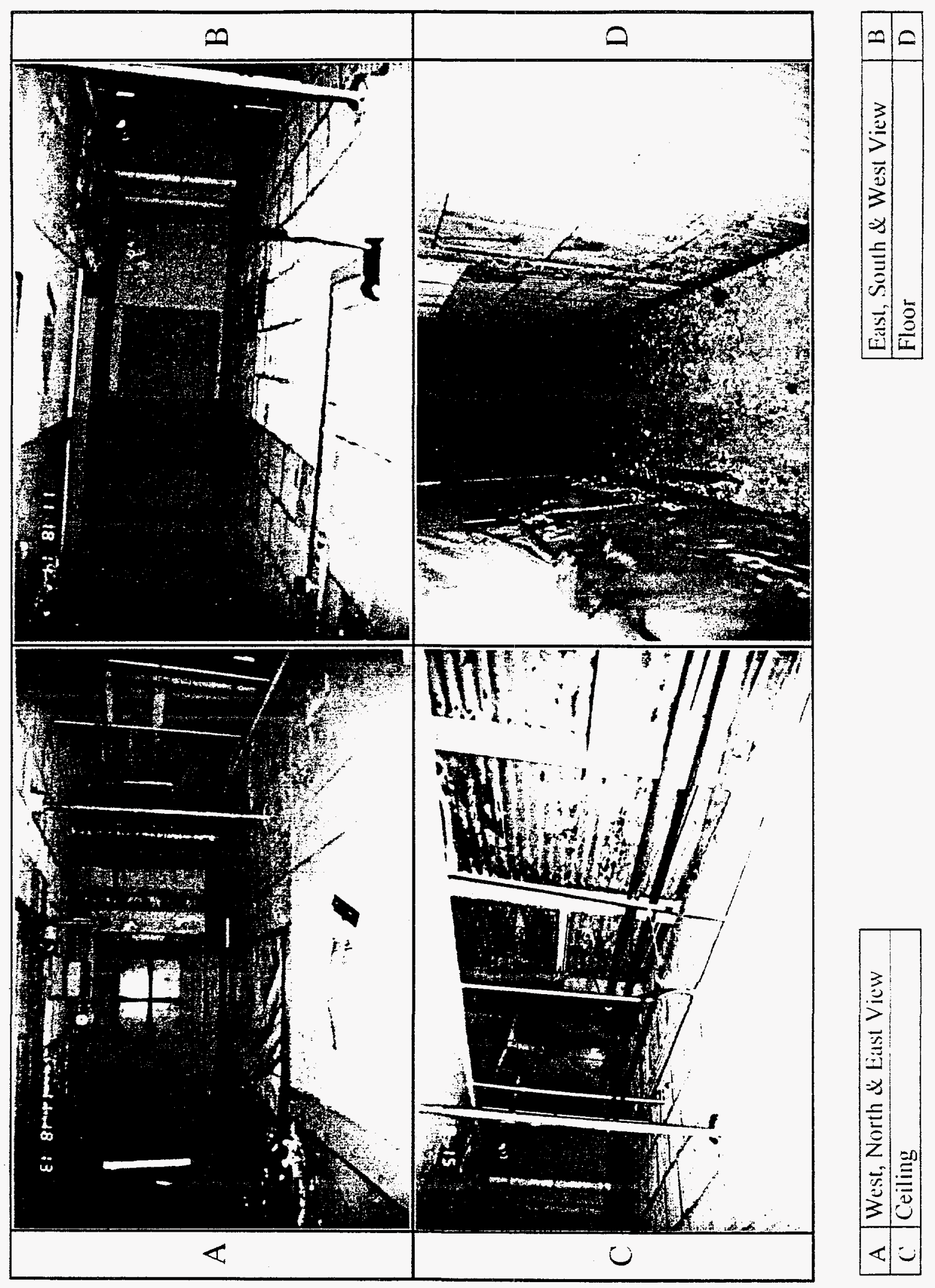

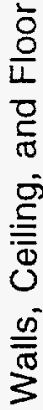

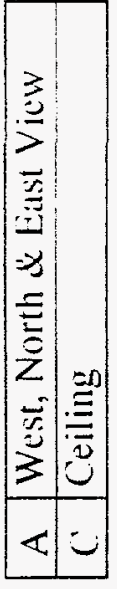

ह 


\subsubsection{Equipment}

Some scrap metal was found in cubicles $1 \mathrm{~A}$ and $2 \mathrm{~A}$. Three air vents are located on the roof of the four cubicles.

\subsubsection{Doors and Windows}

A set of double doors leads from the outside to each of the four cubicles.

\subsubsection{Ceiling and Floor}

The roof of the cubicles is constructed of an asphalt material covered with tar. The roof has deteriorated, and standing water was observed in cubicles $2 \mathrm{~A}, 3 \mathrm{~A}$, and $4 \mathrm{~A}$ at the time of the site investigation. The floor each of the cubicles is constructed of concrete tiles surrounded by a concrete wall footing. 


\section{Geophysical Investigation}

Two geographical investigations were performed by ANL in the vicinity of Building E5032. An initial geophysical investigation was conducted in April 1991 (McGinnis et al. 1991) followed by a resurvey investigation in 1994 (Thompson et al. 1994).

Results from the 1991 survey permit the following conclusions:

- Geophysical measurements from magnetics, GPR, and resistivity survey data collected over a buried concrete slab approximately $130 \mathrm{ft}$ north of Building E5032 reveal geophysical signatures interpreted to be caused by a large iron tank or vault. This feature may be the remnant of Building 91 .

- Three magnetic anomalies centered at approximately $30 \mathrm{ft}$ north and $10 \mathrm{ft}$ west, $45 \mathrm{ft}$ north and $10 \mathrm{ft}$ west, and $45 \mathrm{ft}$ north and $50 \mathrm{ft}$ west (measured from the northeast corner of the building) appear to be caused by buried tanks.

During the January 1994 geophysical investigation, ANL employed new instrumentation, including two types of electromagnetic induction instruments and a cesium vapor magnetometer, to identify underground structures located near Building E5032. The following conclusions were drawn from the 1994 investigation at Building E5032:

- A prominent northeast/southeast-trending conductivity lineament extends from the northeast corner of the building to an exposed steel culvert. The presence of sewer grates adjacent to the building and the steel culvert to the northeast indicate that a drain/storm line is the source of these anomalies.

- An east/west-trending, positive-amplitude, electromagnetic field (EMF) anomaly that extends across the survey area just a few feet north of Building E5032 and is interpreted to be a sanitary sewer line. A subtle, east/westoriented depression, spatially aligned with the geophysical anomalies, was observed in the grassy area east of Building E5032.

- The magnetics and induced electromagnetic measurements detected an anomalous, north/south-trending lineament that begins $20 \mathrm{ft}$ north of the northeast corner of the building and extends over a north/south-oriented ditch. The strength of the conductivity anomaly suggests the potential for an underground drain line.

- A north/south-trending cluster of anomalies is anchored on the north end by a buried vault or a steel tank and may be related to the old Building 91 structure described in a prior geophysical report ( McGinnis et al. 1991). 
- The conductivity data indicate a northeast/southwest-trending conductivity low that extends from a sump works on the building's western wall to the opening of the drainage ditch that runs around the southern and eastern perimeters of the building. The shape and strength of this anomaly indicate the presence of a buried drain line connecting the sump works and the drainage ditch.

The geophysical investigation did not confirm the presence of the HMFs identified in the ANL $1994 \mathrm{HMF}$ field investigation. However, the investigation identified sewer/drain lines extending from the northeast corner and along the west side of the building where HMFs are located. No significant anomalies were identified on the south end of the building. The study area south of the building was limited for the geophysical investigation. By extending the study area south, ANL may have identified more anomalies originating from the four sumps located south of the building. 
6 Air Quality Monitoring

No air quality information for Building E5032 is available. 


\section{Underground Storage Tanks}

ANL conducted a field investigation of HMFs located in and around APG buildings, including Building E5032 (Cobo 1994). The field investigations consisted of reviewing historical documents describing HMFs, identifying the facilities, and sampling liquids present in the HMFs for each of the buildings included in the survey. The following are findings from the HMF field investigation for Building E5032:

- A Consent Order between APG and the Waste Management Administration, Maryland Department of Environment, identified six HMFs associated with Building E5032. Historical records and the analytical results indicate that, because the HMFs located at Building E5032 discharged to a sewer line or creek, they were regulated under the Clean Water Act, rather than the state's UST program (Cobo 1994).

- Seven exterior and two interior sumps are associated with Building E5032. Two of the exterior sumps are located adjacent to the building on the west side, four are located next to the four bays on the south side, and one is located in the northeast corner of the building. These sumps are designated as SWMUs (Cobo 1994). Any further activity related to these sumps should follow CERCLA remedial investigation guidelines (Cobo 1994). 


\section{Conclusions}

Results of the geophysical surveys indicate some anomalies in the vicinity of Building E5032 that warrant further investigation and evaluation. Geophysical measurements reveal signatures interpreted to be caused by a large iron tank or vault located approximately $130 \mathrm{ft}$ north of Building E5032. Magnetic anomalies approximately 30 to $50 \mathrm{ft}$ north and 10 to $15 \mathrm{ft}$ west, and $45 \mathrm{ft}$ north and $50 \mathrm{ft}$ west (measured from the northeast corner of Building E5032), appear to be caused by buried tanks. Additional anomalies suggest the presence of various underground sanitary sewer, drainage, and storm water lines.

Review of the HMF report (Cobo 1994) indicates that seven exterior and two interior sumps associated with Building E5032 are designated to be SWMUs. Any further regulatory activity for those sumps should follow CERCLA remedial investigation guidelines. In addition, six HMFs identified in the Consent Order as being associated with Building E5032 were determined to be regulated under the Clean Water Act, rather than the state's UST program.

An air quality monitoring program should be conducted to establish potential sources of air contamination within Building E5032. Asbestos testing is recommended for the various suspect asbestos-containing pipe insulation observed inside Building E5032. 


\section{References}

Cobo, H., 1994, unpublished information.

McGinnis, L.D., and S.F. Miller, 1991, Interim Progress Report - Geophysics: Building E5032 Decommissioning, Aberdeen Proving Ground, ANL/ESD/TM-20, Argonne National Laboratory, Argonne, Ill.

Nemeth, G.,1989, RCRA Facility Assessment Report, Edgewood Area, Aberdeen Proving Ground, Maryland, unnumbered report prepared by U.S. Army Environmental Hygiene Agency for Aberdeen Proving Ground, Md.

Thompson, M.D., et al., 1994, Interim Progress Report Addendum - Environmental Geophysics: Building E5032 Decommissioning, Aberdeen Proving Ground, January 1994 Resurvey, ANL/ESD/TM-85, Argonne National Laboratory, Argonne, Ill.

Yon, R.L., 1988, Building E5625 Usage Survey/Historical Records Search, Delivery Order 0606, U.S. Army Chemical Research, Development, and Engineering Center, Aberdeen Proving Ground, $\mathrm{Md}$. 
Appendix A:

Field Investigation of Hazardous Material Facilities for Building E5032 


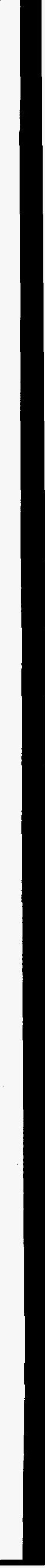


FIELD INVESTIGATION RESULTS

FOR BUILDING E-5032, EDGEWOOD AREA,

ABERDEEN PROVING GROUND, MARYLAND

HMF Record Nos: $\quad 91699$

91700

91701

91708

91709

91710

Prepared by

Reclamation Engineering and Geosciences Section

Energy Systems Division

Argonne National Laboratory

Submitted to

U.S. Army

Directorate of Safety, Health, and Environment

Aberdeen Proving Ground, Maryland 


\section{Contents}

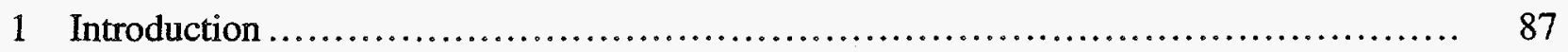

2. Results of the Geophysical Investigation ...................................... 91

3 Results of the HMF-Content Analyses .......................................... 97

4 Results of the Subsurface Investigation ......................................... 99

5 Conclusions and Recommendations............................................. 101

5.1 Conclusions .............................................................. 101

5.2 Recommendations .......................................................... 101

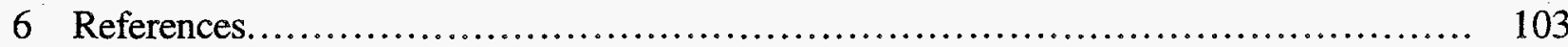

Attachment A: Standard Operating Procedure for Analytical Methods,

Chain of Custody, Analytical Request and Results,

Method Detection Levels, and Minimum Detection Limits.............. 105

Attachment B: Analytical Summary Table for Building E-5032 ................... 115

\section{Figures}

1 General Site Map of Canal Creek Area, Aberdeen Proving Ground, Maryland..... 89

2 Site Map Showing the Outline of Building E-5032 and the Grid Spacing ............... 92

3 Magnetic Map of the Flat Area North of the Building.............................. 93

4 Ground-Penetrating-Radar (GPR) Signature over Buried Tank or Vault Centered at Coordinates 220N,065W along North-South Axis of the Object.

5 GPR Signature over Buried Tank or Vault along East-West Axis of the Object........... 95 


\section{Introduction}

Building E-5032 (Figure 1) is located on an unnamed frontage road, at the northwest corner of the intersection of Magnolia and Hoadley Roads. The building is a concrete and corrugatedmetal structure built in 1918 as an incendiary drop-bomb filling facility for the MKI and MKII drop bombs. In 1922 the building was used as an explosive manufacturing complex (laboratory scale). The date that this activity was terminated is unknown. The building has been used as a miscellaneous pilot plant for many operations. Chemical agents used or tested at this facility include H, WP, GA, and incendiaries. Pre-World War II work at Building E-5032 included chemical-warfare pilot-plant testing. All activity at Building E-5032 stopped in 1974 (Nemeth 1989).

Seven exterior and two interior sumps are associated with Building E-5032. The sumps contain unknown chemicals that should be considered toxic and should not be handled prior to conducting a full analysis. Two of the exterior sumps are located adjacent to the building on the west side, four are near the four bays on the south side, and one is located at the northeast corner of the building. All sumps are connected to the chemical sewer system, which received most or all of the production-operation wastewater. The wastewater was then discharged to Canal Creek, eastsoutheast of the building. The wastewater system sumps are SWMUs. An additional HMF was located by the ANL team during the field inspection. The team located two pipes, either fill or vent pipes, at the northeast corner of the building. Building E-5032 is currently not being used (U.S. Army CRDEC, undated).

The Consent Order identifies six HMFs as being associated with Building E-5032. Information provided in the Consent Order lists these HMFs as follows:

\begin{tabular}{|c|c|c|c|}
\hline $\begin{array}{l}\text { HMF } \\
\text { Number }\end{array}$ & Capacity & Content & $\begin{array}{c}\text { Date } \\
\text { Installed }\end{array}$ \\
\hline 91699 & Unknown & Unknown waste & Unknown \\
\hline 91700 & Unknown & $\begin{array}{l}\text { White phosphorous } \\
\text { and GA agent }\end{array}$ & Unknown \\
\hline 91701 & Unknown & Unknown waste & Unknown \\
\hline 91708 & Unknown & Unknown waste & Unknown \\
\hline 91709 & Unknown & Unknown waste & Unknown \\
\hline 91710 & Unknown & Unknown waste & Unknown \\
\hline
\end{tabular}


The proposed project strategy was to investigate all HMFs suspected of non-UST Program activities under a separate H\&S Plan. Because of potential exposure to CW agents and radioactive isotopes from the non-POL HMFs during content sampling, DSHE provided specialists from the Chemical Operation Branch (COB) of ERDEC to complete the sampling. The H\&S plan required COB personnel to sample the non-POL HMFs wearing the appropriate level of personal protective equipment. The H\&S plan incorporated the POL-content-sampling techniques and procedures set forth in the original Work Plan to retrieve representative samples of the liquid. The liquid samples were then transferred to ERDEC's laboratory located in Building E-3300. The HMF content samples were analyzed for $\mathrm{CW}$ agents $\mathrm{GB}, \mathrm{GD}, \mathrm{GA}, \mathrm{VX}$, and $\mathrm{HD}$ before they were released for commercial laboratory analysis. 


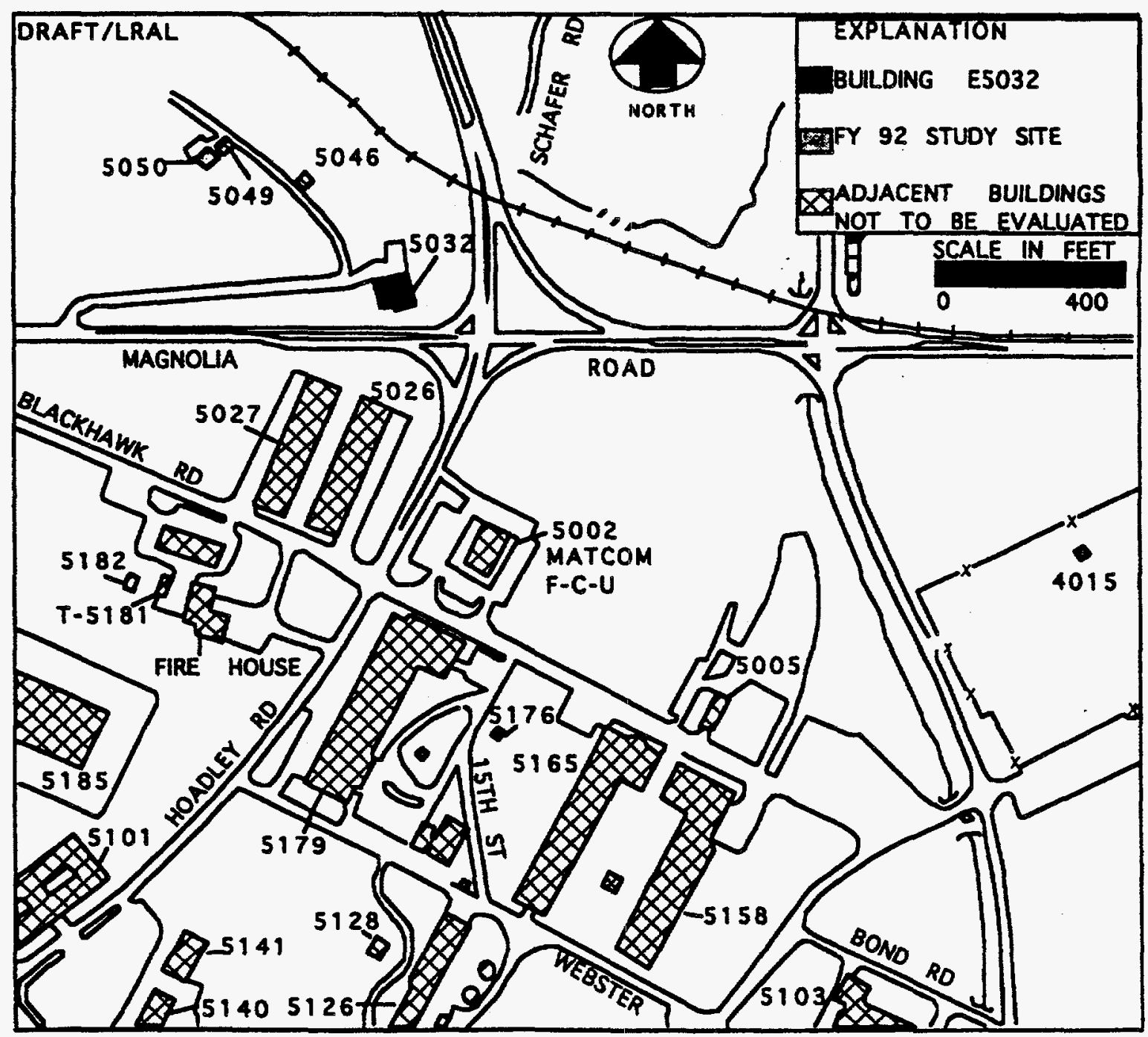

FIGURE 1 General Site Map of Canal Creek Area, Aberdeen Proving Ground, Maryland 


\section{Results of the Geophysical Investigation}

A geophysical survey was performed in 1991 as part of ANL's building decommissioning program for Building E-5032 (McGinnis and Miller, 1991). Geophysical techniques used during the survey included magnetics, direct-current electrical resistivity, and ground-penetrating radar (GPR). The geophysical survey area surrounds Building.E-5032 and covers an area $115 \mathrm{ft} \times 230 \mathrm{ft}$ (Figure 2). Results for the geophysical survey are summarized in the McGinnis and Miller report, with detailed figures for the results from each of the geophysical surveys. Additional geophysical surveys were conducted in early 1994 (McGinnis, personal communication; Brubaker, in preparation). Preliminary processing of recent data sets confirms the conclusions of the original survey by McGinnis and Miller (1991).

Strong magnetic anomalies, observed over much of the region north of the building, are attributed to iron pipes, buried tanks, remnants of a former railroad line, and other metallic debris (Figure 3). One strong anomaly approximately $130 \mathrm{ft}$ north of the building appears to be caused by a large iron tank or vault (located at coordinates $220 \mathrm{~N}, 65 \mathrm{~W}$ ). GPR data indicate a strong reflector at the location (Figures 4 and 5). Other magnetic anomalies centered at coordinates $130 \mathrm{~N}, 70 \mathrm{~W} ; 135 \mathrm{~N}, 30 \mathrm{~W} ; 128 \mathrm{~N}, 30 \mathrm{~W}$; and $115 \mathrm{~N}, 30 \mathrm{~W}$ also appear to be caused by buried tanks. However, a concrete slab with steel reinforcement around the anomalies makes positive identification difficult.

Geophysical signal quality south, east, and west of the building was generally poor because of the presence of metallic material on the surface. For additional figures and detailed information about field parameters and instrumentation, refer to the McGinnis and Miller report (1991). 


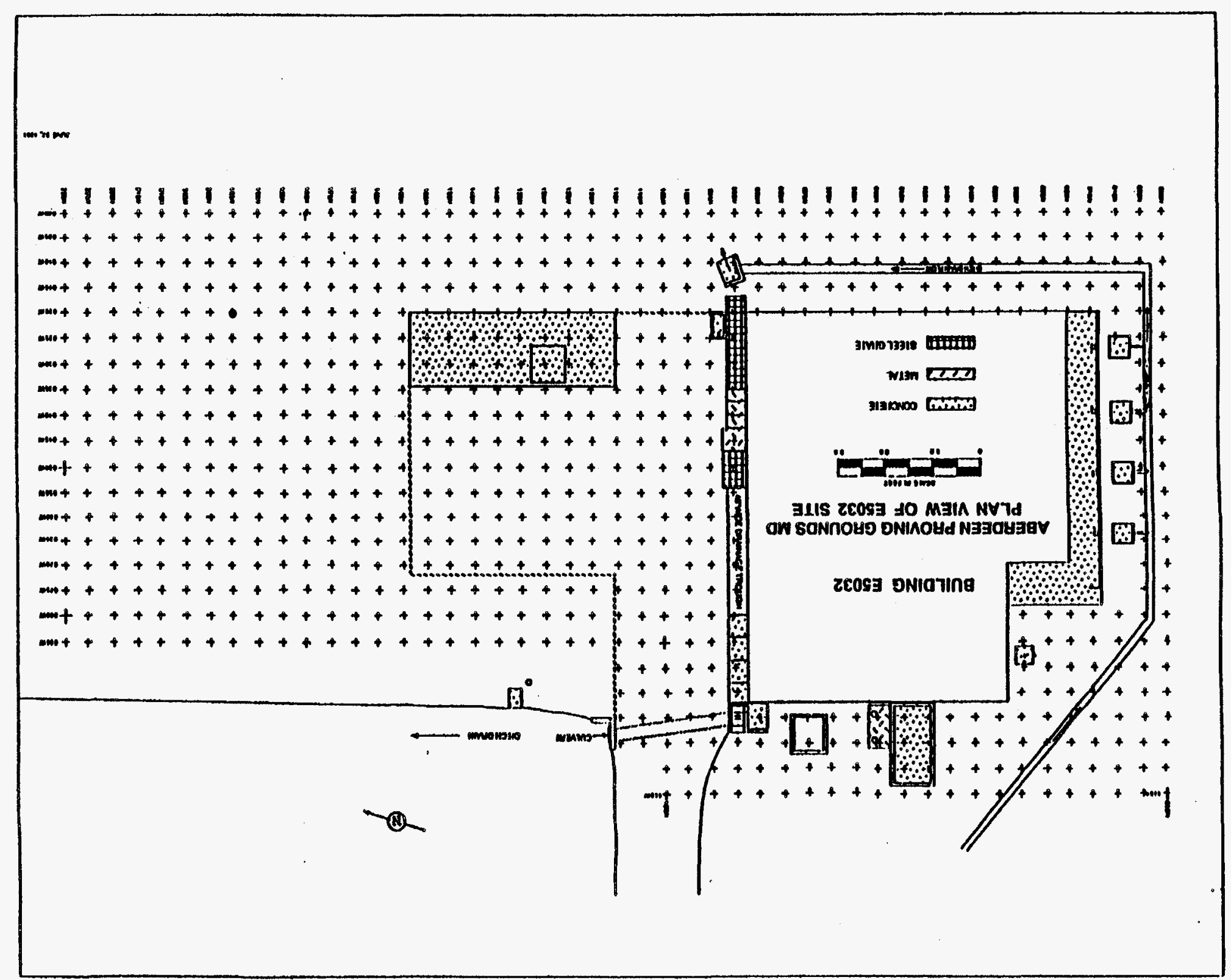




\section{MAGNETIC FEELD INTENSTEY (gammas)}

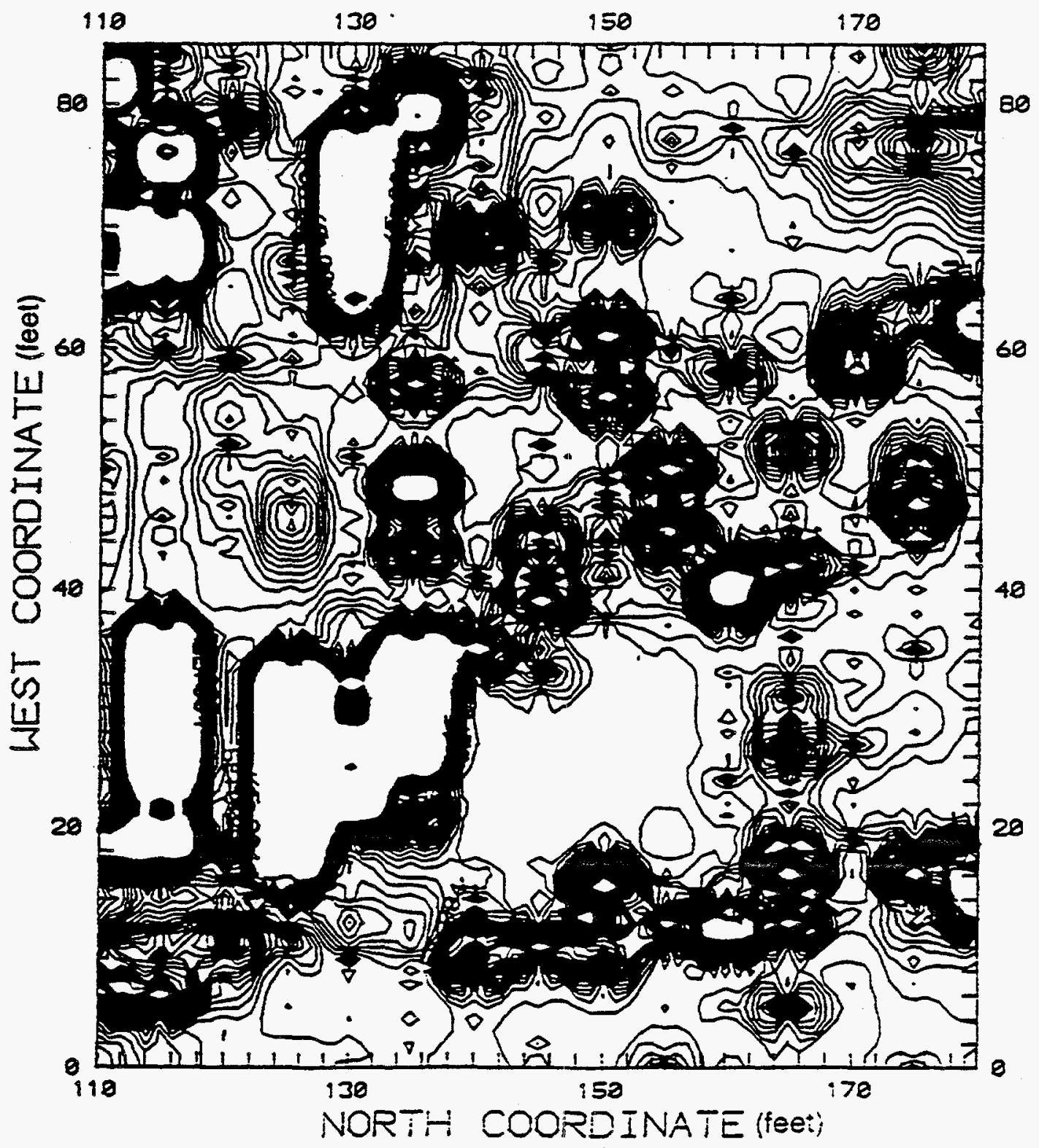

FIGURE 3 Magnetic Map of the Flat Area North of the Building 


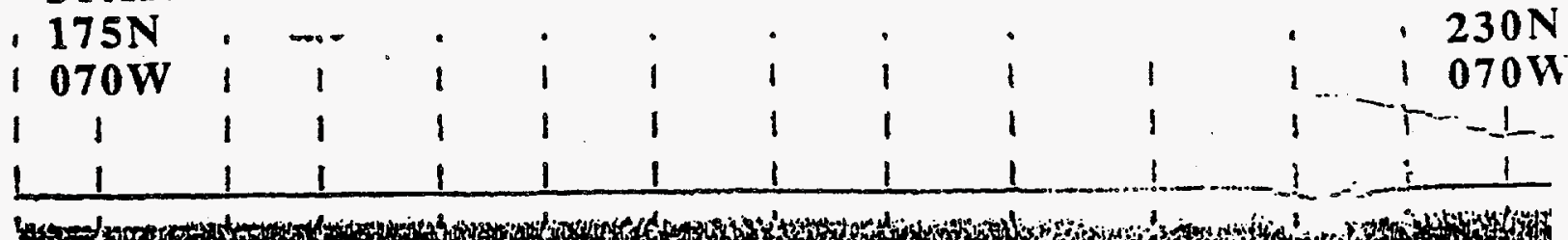

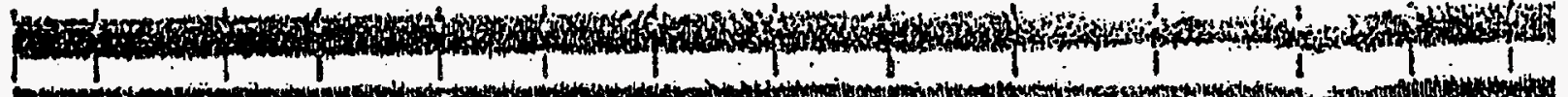
1

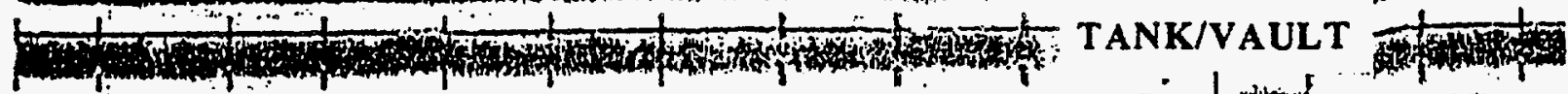

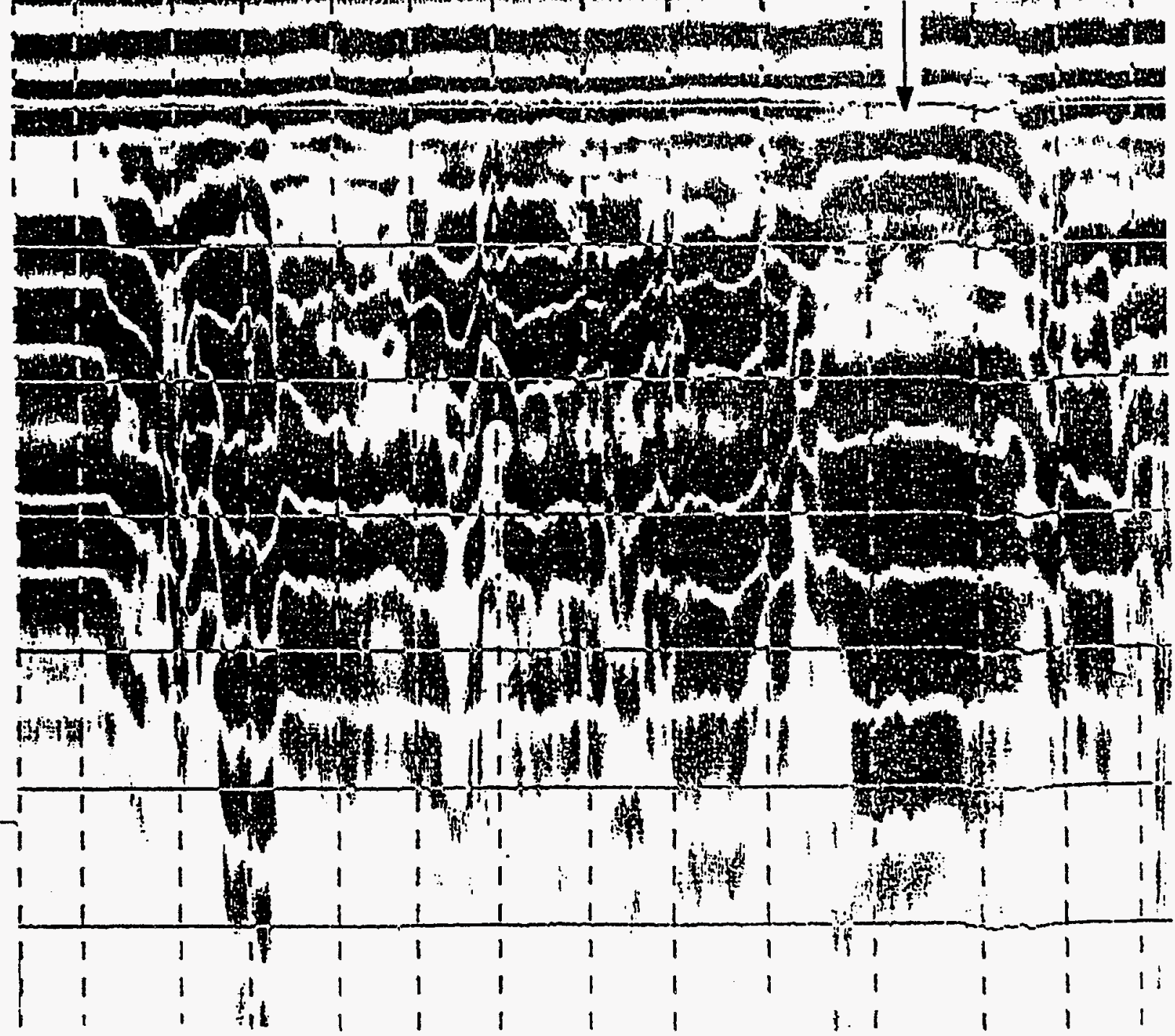

FIGURE 4 Ground-Penetrating-Radar (GPR) Signature over Buried Tank or Vault Centered at Coordinates $220 \mathrm{~N}, 065 \mathrm{~W}$ along North-South Axis of the Object 


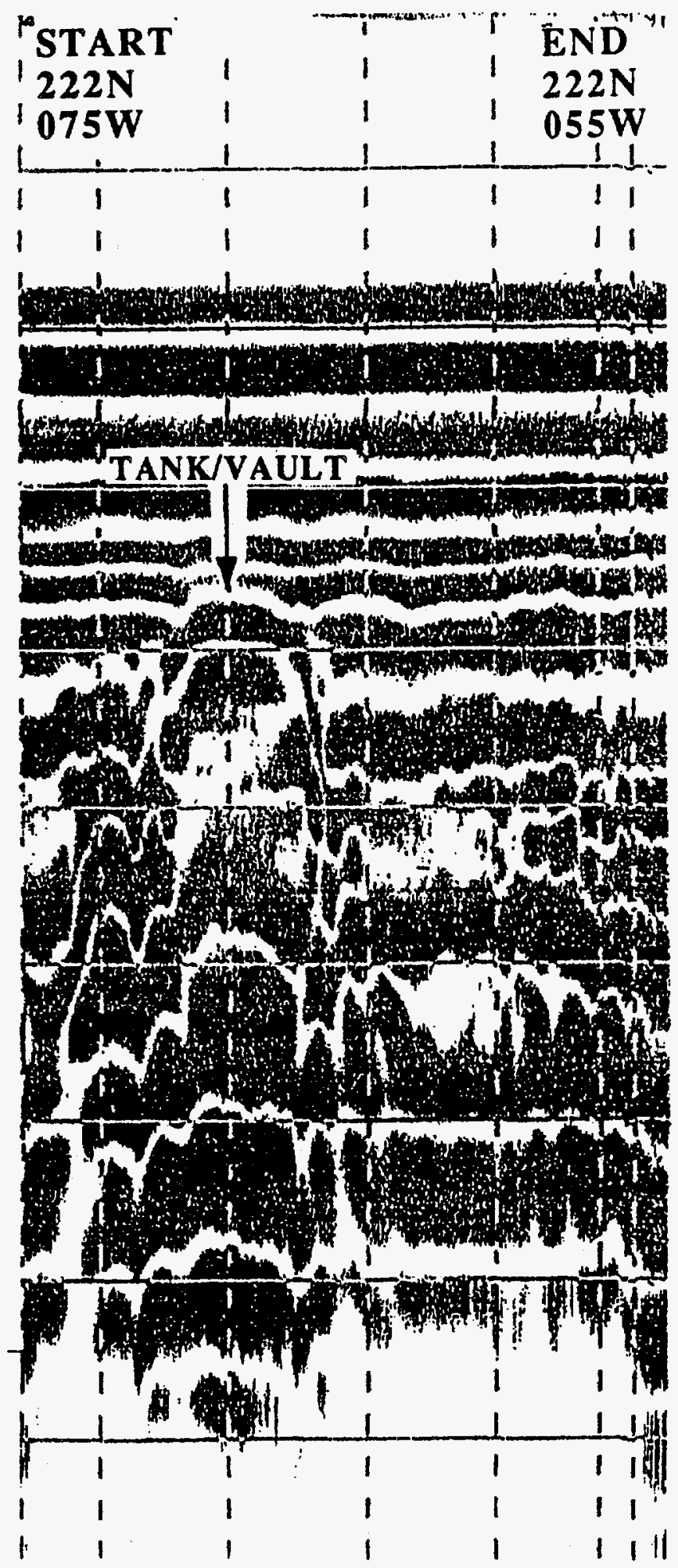

FIGURE 5 GPR Signature over Buried Tank or Vault along East-West Axis of the Object 


\section{Results of the HMF-Content Analyses}

Sampling of the content from the HMFs at Building E-5032 began on November 15, 1993. The ANL team could not correlate any of the existing HMFs with the Consent Order record numbers. The Chemical Operation Branch (COB) sampling team numbered the HMFs 1A through $6 \mathrm{~A}$ for sampling purposes. The HMFs associated with the four bays on the south side of the building were numbered as follows: the furthest east $\mathrm{HMF}$ was designated \#1A, followed in order by, \#2A, \#3A, and \#4A. HMF \#5A is located inside the building under a steel grate at the south end of a concrete trench. HMF \#6A is located outside the building at the northeast corner; the location is marked by two vent pipes, each $3 \mathrm{ft}$ tall. Content sampling was accomplished through existing entry ports of the HMFs. The COB sampling team strictly adhered to all provisions in the ANL- and APG-approved Work Plan and H\&S Plan. A peristaltic pump was utilized to retrieve the liquid samples, which were transferred to appropriate glass sample bottles.

The COB team sampled HMFs \#1A through \#5A, observing only a clear liquid, either surface water or groundwater infiltrate. The COB team next attempted to sample HMF \#6A (located at the northeast corner of the building). The tygon tubing was inserted into both vent pipes for a distance of about $3 \mathrm{ft}$ when the tubing struck an obstruction. The team observation noted concrete as the obstruction in both pipes. Historical records do not indicate the HMF abandonment via filling with concrete. The other three exterior sumps could not be sampled due to the lack of sufficient liquid. The remaining interior sump was also in a dry state.

The suspect $\mathrm{CW}$-agent samples were analyzed by Eugene Vickers from the Analytical Research Team (SCBRD-RTC). The samples were analyzed, using the standard operating procedures contained in Appendix A, for the presence of GA, GB, GD, VX, and HD. The instrument detection limit and method detection levels were determined for each sample. The instrument detection limit is defined as the minimum level that the instrument can detect taken directly from the calibration curve, whereas the method detection level is determined from a known amount of a pre-extraction spiked sample (spiked at midpoint of curve). The analytical results were negative for the presence of $\mathrm{CW}$ agents. 
The contents of HMFs \#1A and \#2A were not hazardous, as determined by comparison of the analytical results with the characteristics for RCRA hazardous waste. HMFs \#3A, \#4A, and \#5A were reported with trichlorethene at $1.2,5,580$, and $4.9 \mathrm{ppb}$, respectively. The liquid in all five HMFs was a clear liquid, either surface water or groundwater infiltrate. A summary of the analytical results is presented in Appendix B. 


\section{Results of the Subsurface Investigation}

No subsurface investigation was performed at Building E-5032, because regulated CERCLA activity is planned as an overall Edgewood Area strategy.

The Environmental Conservation and Restoration Division, under the Directorate of Safety, Health, and Environment, is implementing the Installation Restoration Program. U.S. EPA Region III and the MDE Waste Management Administration's Environmental Response and Restoration Program Office have regulatory responsibility and oversight of abandoned non-POL HMFs. 


\section{Conclusions and Recommendations}

\subsection{Conclusions}

On the basis of a review of historical records and HMF-content analytical results, it is determined that the six HMFs located at Building E-5032 are not regulated under the UST Program directed by MDE. These HMFs were regulated under the Clean Water Act, because the liquids in the HMFs discharged to a sewer line or to a creek, marsh, or river, and consequently, these HMFs are excluded from the UST Program.

The seven exterior and two interior HMFs were flow-through sumps for the CW agent processes that discharge to the chemical sewer system. The ANL team could not find any documentation on the concrete-filled HMF (\#6A). The vent pipes may be part of the storage HMF or a vent vault or sump. However, because of the presence of the reinforced concrete, the geophysical techniques could not confirm the locations of the HMFs. The chemical-sewer system handled the chemical surety and agent-production-operation wastewater and discharged to the east branch of Canal Creek. The wastewater-system sumps are designated SWMUs; any further regulatory activity should follow CERCLA remedial investigative guidelines.

\subsection{Recommendations}

The Environmental Conservation and Restoration Division, under the Directorate of Safety, Health, and Environment, is implementing the Installation Restoration Program. U.S. EPA Region III and the MDE Waste Management Administration's Environmental Response and Restoration Program Office have regulatory responsibility and supervision of abandoned non-POL HMFs.

On the basis of a review of the HMF-content-sample analyses and the regulatory responsibility stated above, ANL recommends the following remedial action for Building E-5032:

- Direct further remedial activity under the CERCLA guidelines, currently under the direction of the Environmental Conservation and Restoration Division. 


\section{References}

EAI Corporation, 1989, Historical Records Search and Site Survey of Edgewood Area Buildings, Final Report, U.S. Army Chemical Research, Development and Engineering Center, Contract No. DAAA15-87-D-0021, August.

McGinnis, L. D. and S. F. Miller, 1991, Interim Progress Report - Geophysics: Building E-5032 Decommissioning, Aberdeen Proving Ground, report ANL/ESD/TM-20, Argonne National Laboratory, Argonne, Ill.

Nemeth, G., 1989, RCRA Facility Assessment, Edgewood Area, Aberdeen Proving Ground, Maryland, Waste Disposal Engineering Division, U.S. Army Environmental Hygiene Agency, prepared for Aberdeen Proving Ground, Test and Evaluation Command, U.S. Army Material Command, November.

U.S. Army Chemical Research, Development and Engineering Center (CRDEC), undated, Underground Storage Tank Management Program. 
Attachment A:

Standard Operating Procedure for Analytical Methods, Chain of Custody, Analytical Request and Results, Method Detection Levels, and Minimum Detection Limits 


\section{Standard Operating Procedure for Analytical Methods}

The extraction procedures for analysis of aqueous samples from the HMFs for agents GA, GB, GD, VX, and HD are the procedures used in IOP No. 003.10, November 1991, with modification.

\subsection{Experimental Procedure}

1.1 Visually inspect the sample and note observations regarding color, consistency, and solids on data/notebook sheet.

1.2 Obtain two 200-mL aliquots of aqueous layer. One will be used for the spiked solution and one for the unspiked solution. The steps described below are performed on each aliquot.

1.3 Pour the aliquot into a clean beaker, mix, and check $\mathrm{pH}$. Record $\mathrm{pH}$.

1.4 Weigh out $4.0 \mathrm{~g}$ of $\mathrm{NaCl}$ and place in a separatory funnel. Add the $200-\mathrm{mL}$ aliquot of filtered sample. Swirl the separatory funnel until the $\mathrm{NaCl}$ is dissolved.

1.5 Add $4 \mathrm{~mL}$ of chloroform to the $200-\mathrm{mL}$ aliquot of sample in the separatory funnel. Agitate the separatory funnel contents for $1 \mathrm{~min}$, and allow the layers to separate for a minimum of $3 \mathrm{~min}$.

1.6 To prepare the spike sample, add $200 \mu \mathrm{L}$ of HD standard agent matrix spike solution and $75 \mu \mathrm{L}$ of GA, GB, GD, and VX spike solutions.

1.7 Drain the chloroform (bottom) layer into a clean, $15-\mathrm{mL}$ centrifuge tube.

1.8 Transfer $1.0 \mathrm{~mL}$ of the spiked (or unspiked) solution to a $2-\mathrm{mL} \mathrm{GC} \mathrm{vial.}$

1.9 Add $100 \mu \mathrm{L}$ of internal standard solution (dibutylbutylphosphonate [DBBP] for VX, GA, GB, and GD and diethylsulfide [DES] for HD). 
1.10 Cap the vial and store the sample in refrigerator at $4^{\circ} \mathrm{C}$ until ready for analysis.

\subsection{Spiking and Chromatography Procedure}

2.1 Sample extracts, standards in chloroform, and spiked site-background samples are received in the $2-\mathrm{mL}$ sample vials and signed for . All of the standards and samples will contain the internal standards (IS) DBBP and DES of known concentration.

2.2 The samples are run in the gas chromatograph (GC), and the chromatograms are marked for identification. The peak areas and retention times for the internal standards and all agents detected are entered into a laboratory notebook.

2.3 The samples and standards are returned to the person from whom they were received. The chromatograms are given to the data coordinator.

2.4 The auto sampler needle and GC inlet septum are replaced after no more than 90 injections.

\subsection{Calculations}

3.1 The retention time index is a measure of column and instrument performance and is simply the retention time of the agent of interest divided by that of the internal standard.

3.2 Agent quantitation will be determined by using the response factor (RF) of the agent relative to that of the internal standard. The response factor is calculated during the calibration method as follows:

$$
\text { RF }(\text { Agent } / \text { IS })=\frac{\text { Peak Area }(\text { Agent }) \times \text { Concentration }(\text { IS })}{\text { Peak Area }(\text { IS }) \times \text { Concentration }(\text { Agent })}
$$

where Concentration (agent) $=\frac{\mathrm{Wt} \text { of sample }}{\mathrm{Wt} \text { of Internal STD }} \times \mathrm{RF} \times$ area of sample 


\subsection{Quality Control}

4.1 The calibration curve will consist of duplicate injections of the agents, once each quarter. The samples are loaded in the auto-sampler tray in a random order.

4.2 For each analysis, a duplicate phase (oil, aqueous, solid) sample, a midpoint standard (two cocktails of G/H series and V series), a blank, and spiked phase (oil, aqueous, solid) samples will be run. The order of analysis in the autosampler tray will be

$\begin{array}{ll}\text { Position \#1: } & \text { Blank } \\ \text { Position \#2: } & \text { Mid-Pt (G/H Series) } \\ \text { Position \#3: } & \text { Mid-Pt (VX Series) } \\ \text { Position \#4: } & \text { Phase Oil (1) Sample } \\ \text { Position \#5: } & \text { Phase AQ (1) Sample } \\ \text { Position \#6: } & \text { Phase Solid (1) Sample } \\ \text { Position \#7: } & \text { Phase Oil (2) Sample } \\ \text { Position \#8: } & \text { Phase AQ (2) Sample } \\ \text { Position \#9: } & \text { Phase Solid (2) Sample } \\ \text { Position \#10: } & \text { Spiked-Phase Oil (1) Sample } \\ \text { Position \#11: } & \text { Spiked-Phase Solid (1) Sample } \\ \text { Position \#12: } & \text { Spiked-Phase Solid (1) Sample }\end{array}$

4.3 The midpoint standards must be within $\pm 10 \%$ of the calibration or the samples must be reanalyzed.

4.4 Maintain documentation of standard-curve concentrations, as well as maintain the internal standard concentration for each sample.

4.5 Record retention times for the standard midpoints and the internal standards.

4.6 Label and review each chromatogram prior to submission to the data coordinator. 
4.7 Record the peak areas for the standard midpoints and for the internal standards.

4.8 Refer to IOP No. 014.10 "Quality Control and Data Validation Procedures" for related information.

4.9 The peak area of the internal standard will be monitored. The area should come within $\pm 10 \%$ of its original response time calibration curves.

4.10 The retention time of the internal standard will be monitored. The time shall be within \pm 5 seconds of its original response time. 


\begin{tabular}{|c|c|c|c|c|c|}
\hline MATERIEL COURIER RECEIPT & \multirow{3}{*}{ 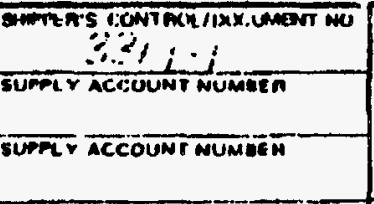 } & \\
\hline कinderan & & & & & \\
\hline 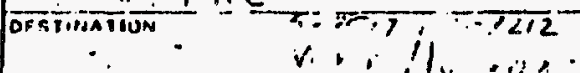 & & \multicolumn{4}{|c|}{ 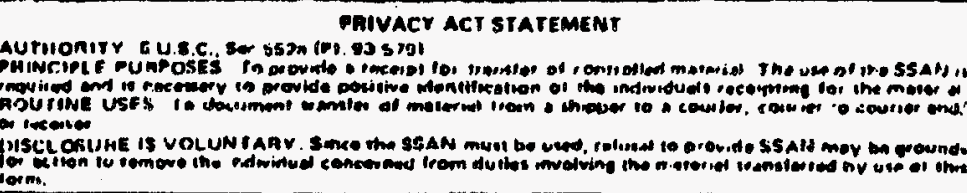 } \\
\hline \multirow{2}{*}{\multicolumn{2}{|c|}{ 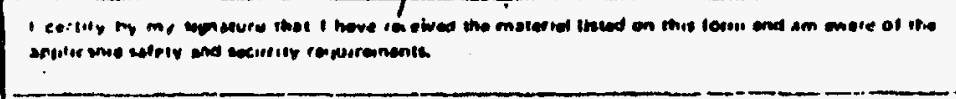 }} & \multicolumn{4}{|c|}{ SHIPMENT DESCRIPTION } \\
\hline & & Lime menougen & QuNowner & SE RiAL NUMBEERS & REMAGKS \\
\hline \multicolumn{2}{|c|}{ SHIPMENT TRANSFERS } & i & & $A$ & \multirow{2}{*}{ Erom Tauk at s 5032} \\
\hline rans $E 3300$ & Tonirininionari & $\dot{4}$ & & $\angle A$ & \\
\hline 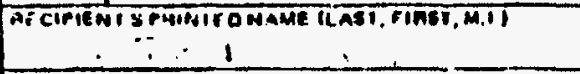 & 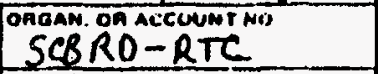 & $\therefore$ & 1 & $3 f_{1}$ & \\
\hline Sigrofillat & 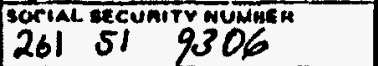 & $i$ & $i$ & $-A$ & \\
\hline seconoj E. $\varepsilon 300$ & $73 / 11 \cdot 22$ & $\therefore$ & & $5 A$ & \\
\hline 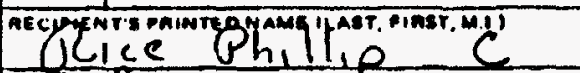 & ERBAM RACCOUNTHAO & 6 & L & 64 & $\angle$ \\
\hline SLeye $R$ i & $212-844-3211$ & & & i: & $-\cdots-$ \\
\hline IMIHD LOCDAOON OF THANAFEH & 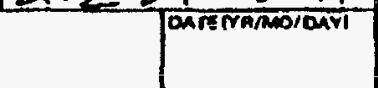 & & & & \\
\hline AECLIPIEN T'S PAINTEO NAME ILAST, WRAT, M.T & OAGAN OT ACCOUNTHU & & & & \\
\hline SHGNATUAE & SOCIAL BECUAIIY MUNBET & & & & \\
\hline 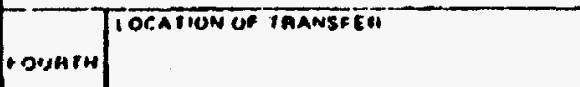 & 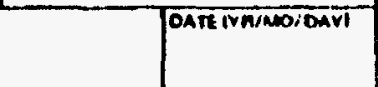 & & & & \\
\hline 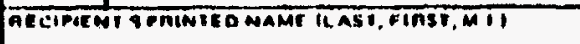 & DASAM OA ACFOONT NO & & & & \\
\hline STGMATUNE & SOCIAL SECUAITY NUMDEA & & & & \\
\hline 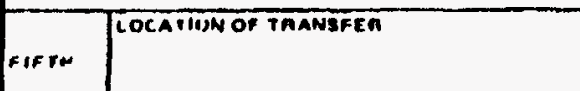 & 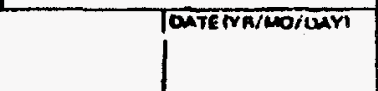 & & & & \\
\hline AECGFIN NI SPATMTEO NAME ILAST FIAST WII & OAGAM OA ACCOUNI MO & & & & \\
\hline SIGNATUAE & SOCIAC SECUMITY NIMAGEA & & & & \\
\hline
\end{tabular}




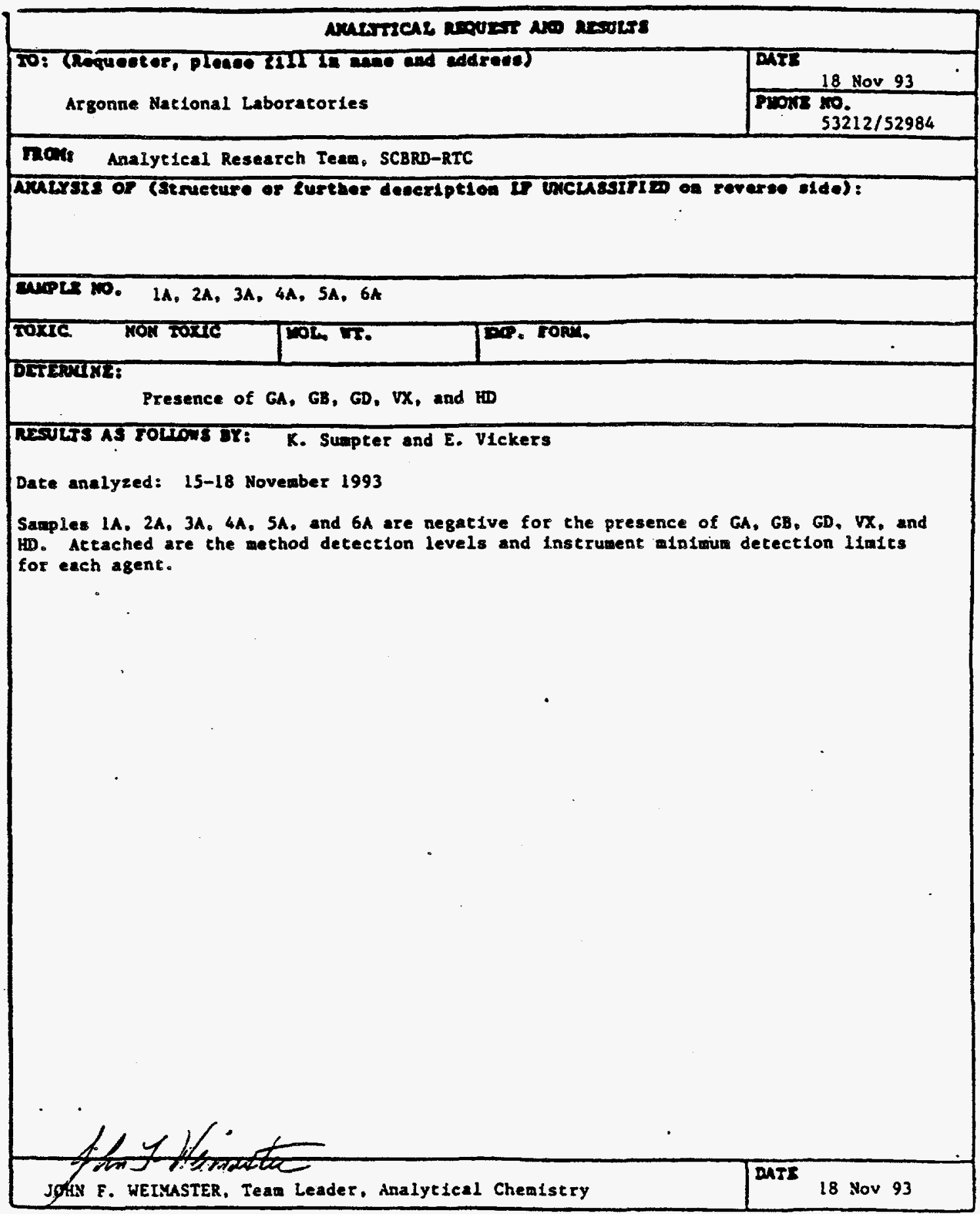

SMCCR Form 49, 1 May 85 replaces ORDAR-CL Form 819. Apr 79 which is obsolete. 


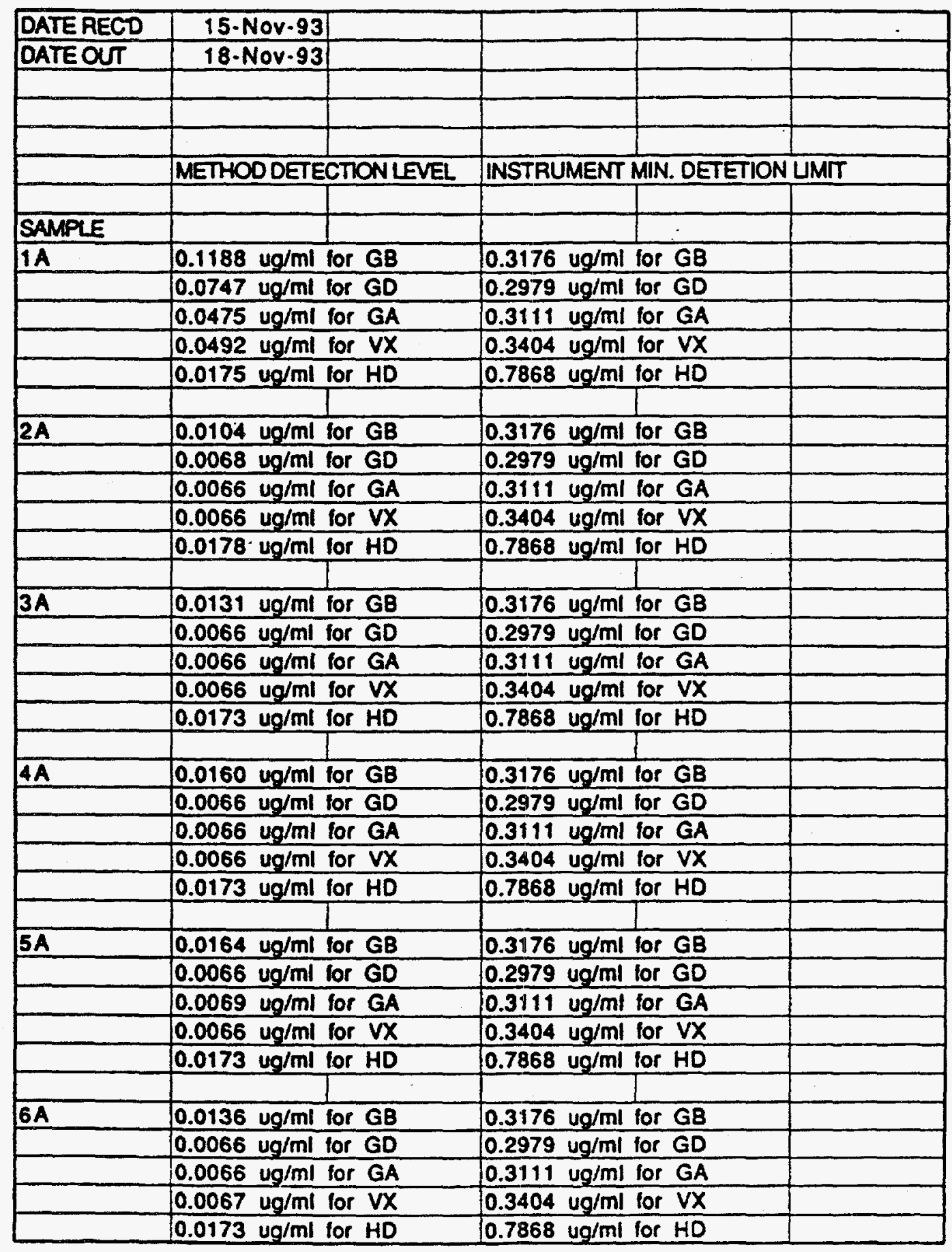


Attachment B:

Analytical Summary Table for Building E-5032

HMF Record Nos: $\quad 91699$

91700

91701

91708

91709

91710 


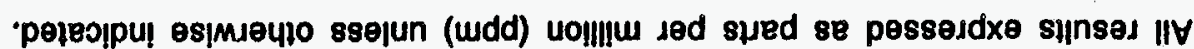

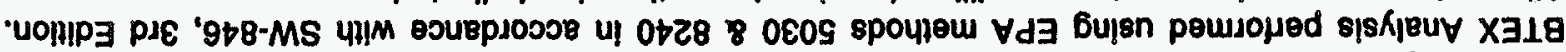

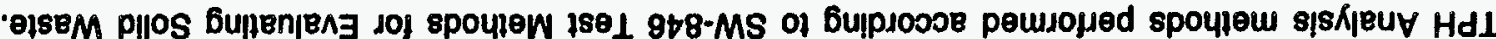
ejdures oN p

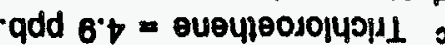

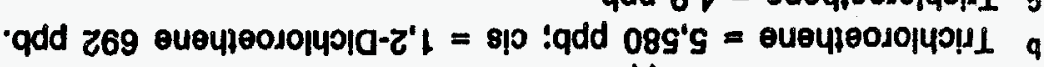
'qdd $Z^{\prime} !$ = ou०upo01014011

\begin{tabular}{|c|c|c|c|c|c|c|c|c|c|c|c|c|c|}
\hline & & & & & & & & & \multicolumn{5}{|c|}{ pOLLL6 } \\
\hline & & & & & & & & & \multicolumn{2}{|l|}{6.2} & tZZIMd & $060 \angle 16$ & \\
\hline 0.0 & $9 \cdot 0>$ & S.0> & $9.0>$ & $\mathrm{S}^{\circ} \mathbf{0}$ & $1.0>$ & $10>$ & $10>$ & $10>$ & \multicolumn{2}{|c|}{1.2} & 8lZlMd & $q 80<16$ & \\
\hline 0.0 & $9.0>$ & s.0> & $9.0>$ & $9.0>$ & $10>$ & $10>$ & 100 & $10>$ & 8.2 & \multirow[t]{3}{*}{ Bgzl:0 } & ZICIMd & $.10<16$ & \\
\hline s.0 & $9^{\circ} 0>$ & $\mathrm{S}^{\circ} \mathrm{O}$ & $9.0>$ & $9.0>$ & $10>$ & $1 \cdot 0>$ & 100 & $10>$ & \multirow{2}{*}{$\begin{array}{l}06 \cdot 9 \\
0<\cdot 9\end{array}$} & & 902IMd & $00 \angle 16$ & \\
\hline 0.0 & 9.0> & $9^{\circ} 0>$ & $9.0>$ & $9 \cdot 0>$ & $10>$ & $10>$ & 100 & $10>$ & & & 00ZlMd & 66916 & ट६09ᄏ] \\
\hline $\begin{array}{l}\text { X710 } \\
\text { je101 }\end{array}$ & बue $K \bar{X}$ & euenjoI & 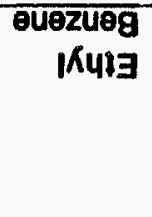 & मеzueg & 18101 & 8uा10885 & 10sela & 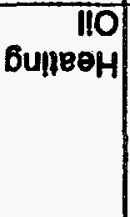 & \multirow[t]{2}{*}{ Hd } & \multirow[t]{2}{*}{$\begin{array}{r}\text { llwi7 } \\
\text { uolposed } \\
\text { enoq } \\
\text { sunsey } \\
\text { d7DL }\end{array}$} & \# өldures \# & p1000प्ष & \multirow[t]{2}{*}{ bu!pinng } \\
\hline \multicolumn{5}{|c|}{$\begin{array}{l}\text { (qdd) } \\
x \in 18\end{array}$} & \multicolumn{4}{|c|}{ 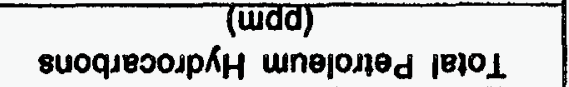 } & & & & & \\
\hline
\end{tabular}

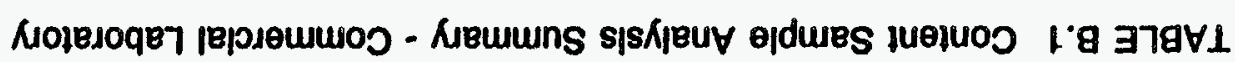

